UNIVERSIDADE DE SÃO PAULO

FACULDADE DE ECONOMIA, ADMINISTRAÇÃO E CONTABILIDADE

DEPARTAMENTO DE CONTABILIDADE E ATUÁRIA

PROGRAMA DE PÓS-GRADUAÇÃO EM CONTROLADORIA E CONTABILIDADE

Patrícia Romualdo de Almeida

\title{
Prospecção acerca de um prazo ótimo para rodízio de firmas de auditoria no Brasil
}

São Paulo 
Prof. Dr. Marco Antonio Zago

Reitor da Universidade de São Paulo

Prof. Dr. Adalberto Américo Fischmann

Diretor da Faculdade de Economia, Administração e Contabilidade

Prof. Dr. Ariovaldo dos Santos

Chefe do Departamento de Contabilidade e Atuária

Prof. Dr. Lucas Ayres Barreira de Campos Barros

Coordenador do Programa de Pós-Graduação em Controladoria e Contabilidade 
Patrícia Romualdo de Almeida

\section{Prospecção acerca de um prazo ótimo para rodízio de firmas de auditoria no Brasil}

Tese apresentada ao programa de PósGraduação em Controladoria e Contabilidade do Departamento de Contabilidade e Atuária da Faculdade de Economia, Administração e Contabilidade da Universidade de São Paulo como requisito parcial para obtenção do título de Doutora em Ciências.

Área de concentração - Mercados Financeiros, de Créditos e de Capitais.

Orientador: Prof. Dr. Luiz Nelson Guedes de Carvalho

Versão corrigida

São Paulo 
FICHA CATALOGRÁFICA

Elaborada pela Seção de Processamento Técnico do SBD/FEA/USP

Almeida, Patrícia Romualdo de

Prospecção acerca de um prazo ótimo para rodízio de firmas de auditoria no Brasil / Patrícia Romualdo de Almeida. - São Paulo, 2017. $136 \mathrm{p}$.

Tese (Doutorado) - Universidade de São Paulo, 2017.

Orientador: Luiz Nelson Guedes de Carvalho.

1. Auditoria externa 2. Contabilidade financeira 3. Regulamento 4. Mercado aberto I. Universidade de São Paulo. Faculdade de Economia, Administração e Contabilidade. II. Título.

CDD -657.48 
Este trabalho é dedicado à minha filha Manuela, ao meu marido Lucas Mól e à minha mãe Aparecida. 



\section{Agradecimentos}

Talvez esta seja a tarefa mais difícil na conclusão dessa tese: conseguir agradecer a todos, que de alguma forma, contribuíram para que eu cumprisse mais essa etapa da minha vida.

Primeiramente, agradeço a Deus, que sabiamente me deixou míope diante das maiores dificuldades que se apresentaram, simplesmente para que eu não percebesse a grandeza dos desafios e não perdesse a coragem de continuar. A fé e as orações foram decisivas para que este trabalho fosse concluído.

Prof. Nelson, agradeço imensamente você ter aceitado me orientar e, com tanto brilhantismo, conseguir me ajudar a encontrar um caminho para seguir com meu trabalho. Agradeço ainda, Prof. Nelson, pela sua humanidade no trato pessoal e por ser força para seus alunos, quando as pernas enfraquecem. Obrigada por me atender sempre prontamente todas as vezes que precisei, apesar de sua agenda sempre lotada. O senhor será sempre minha referência profissional.

Ao Prof. Guilhermo Oscar Braunbeck pela incansável atenção, dedicação e paciência que teve comigo a todo o tempo, me atendendo sempre com tanta boa vontade e agilidade. Sua ajuda foi mesmo a de um coorientador. Obrigada também pela base de dados do IQUA, essencial à execução desse trabalho. Pela base de dados, agradeço também, ao colega Rudah Luccas.

Ao Prof. Luíz Paulo Fávero, agradeço pela orientação inicial desse trabalho.

Ao meu marido Lucas Mól, gostaria de agradecer a paciência "quase" infinita nos momentos de nervosismo e tensão, aos ensinamentos diários, à compreensão das ausências decorrentes do vasto tempo dedicado aos estudos e, sobretudo, ao companheirismo que o fez até procurar aprender um pouco do assunto do trabalho simplesmente para me ajudar nas discussões.

À minha mãe, que esteve ao meu lado a todo momento, me ajudando a cuidar da minha filha, sendo meus olhos, meus ouvidos e meu coração em casa, para que eu tivesse condições de me dedicar à essa tese.

Agradeço à minha filha por me conceder sempre um sorriso nos momentos mais difíceis, recarregando minhas forças para seguir adiante.

A todos os professores da pós-graduação em Controladoria e Contabilidade que, com tanta responsabilidade e dedicação, se empenharam para trazer conhecimentos importantes e atualizados, indo além do exigido pelas disciplinas e buscando sempre apoiar os alunos em seu amadurecimento profissional.

Agradeço também à minha família que esteve sempre ao meu lado.

À Gislaine, secretária do Prof. Nelson, que, sempre solicita, amável e muito profissional, me ajudou durante todo o decorrer do meu doutoramento. Sua competência e desejo de ajudar ao próximo serão exemplos que carregarei para a vida, assim como seu sorriso levarei no coração.

Por fim, agradeço à minha família, amigos e colegas, "meus grandes ouvidos", pelo carinho, paciência e atenção. 



\section{Resumo}

O propósito central deste estudo é investigar se existe um prazo "ótimo" para o rodízio mandatório de firmas de auditoria no Brasil. Primeiramente, buscou-se evidências através da percepção de agentes do mercado para fundamentar o desenvolvimento de um modelo de estudo da qualidade de auditoria em função do tempo de relacionamento auditorauditado (tenure), considerando de forma isolada o efeito da tenure nas vertentes da qualidade, competência e independência, de acordo com o conceito de DeAngelo (1981b). Com base em um modelo quadrático, que consiste em uma simplificação do modelo originalmente proposto, foi realizada uma aplicação empírica com dados de companhias abertas brasileiras, listadas na Bovespa, referente ao período de 1998 a 2016. Os resultados sugerem ser possível estimar o prazo "ótimo" para o rodízio mandatório de firmas de auditoria em aproximadamente 5,7 anos. Testes adicionais foram realizados para conferir robustez a este resultado, indicando que o prazo "ótimo" seria em torno de 6 e 8,8 anos. Esses resultados indicam, portanto, que o prazo atualmente utilizado pela CVM (5 anos para empresas que não têm comitê de auditoria estatutário e 10 anos para as que têm) é compatível com os prazos estimados para se estabelecer o maior nível de qualidade média de auditoria possível. Tendo em vista que os prazos estimados são superiores a 5 anos, talvez não haja prejuízos, no que se refere à maximização da qualidade média da auditoria, se o prazo atualmente adotado for ligeiramente estendido.

Palavras-chave: Auditoria, Qualidade da Auditoria, Prazo para rodízio de firmas de auditoria, Rodízio mandatório de firmas de auditoria. 



\section{Abstract}

The aim of this work is to investigate whether there is an "optimal" period for the mandatory audit firm rotation in Brazil. Firstly, evidence was sought through the perception of market agents to support the development of a model of audit quality as a function of the audit tenure, considering separately the effects of audit tenure on the audit quality components, competence and independence, according to DeAngelo's (1981b) concept. Based on a quadratic model, which consists of a simplification of the model originally proposed, an empirical application was made with data from Brazilian companies, listed on Bovespa, for the period from 1998 to 2016. The results suggest that it is possible to estimate an "optimal" audit tenure period for the mandatory audit firm rotation in Brazil around 5.7 years. Additional tests were performed to give robustness to the results, indicating that the "optimal" period would be around 6 and 8.8 years. These results indicate, therefore, that the term currently used by the CVM ( 5 years for companies that do not have statutory audit committee and 10 years for those that have) is compatible with the estimated terms to establish the highest possible level of the average audit quality. Given that the estimated timeframe is greater than 5 years, there may be no impairment in maximizing the average audit quality if the current rotation period is slightly extended.

Keywords: Audit, Audit Quality, Audit Firm Rotation Term, Mandatory Audit Firm Rotation. 



\section{Lista de ilustrações}

Figura 1 - Comportamentos escolhidos no questionário . . . . . . . . . . . . 68

Figura 2 - Comportamento da competência técnica . . . . . . . . . . 70

Figura 3 - Comportamento da independência . . . . . . . . . . . . . 71

Figura 4 - Obtenção do prazo "ótimo" . . . . . . . . . . . . . . . 73

Figura 5 - Qualidade da auditoria em função da tenure para o modelo de suavização do lucro líquido. . . . . . . . . . . . . . . . . . . . . 89

Figura 6 - Ilustração dos pontos de interesse em uma parábola . . . . . . . . . . . 129

Figura 7 - Ilustração para auxiliar na explicação da integração numérica pela regra do trapézio. . . . . . . . . . . . . . . . . . 135 



\section{Lista de tabelas}

Tabela 1 - Publicações relacionadas à auditoria independente em periódicos selecionados. . . . . . . . . . . . . . . . . . . 22

Tabela 2 - O rodízio de auditoria no mundo. . . . . . . . . . . . 47

Tabela 3 - Resumo dos sinais esperados para os coeficientes da equação 3.7 . . . 79

Tabela 4 - Fontes de dados para o teste empírico . . . . . . . . . . . . 82

Tabela 5 - Estatística descritiva das variáveis utilizadas no ajuste quadrático do IQUA . . . . . . . . . . . . . . . . . . . . 82

Tabela 6 - Resultado do ajuste por MQO robusto de acordo com a equação 3.7. $\quad 83$

Tabela 7 - Estatística descritiva das variáveis utilizadas no teste de robustez a partir de accruals discricionários. . . . . . . . . . . . . . . 8 86

Tabela 8 - Resultado do ajuste por MQO robusto dos accruals discricionários obtidos do modelo de Francis e Wang (2008) pela equação 4.1. . . . . . 87

Tabela 9 - Estatística descritiva das variáveis utilizadas no teste de robustez a partir da variabilidade nos lucros líquidos. . . . . . . . . . . . . 88

Tabela 10 - Resultados da análise de suavização de resultados nos lucros líquidos. 88

Tabela 11 - Quadro resumo da bibliografia. . . . . . . . . . . . . . . . . . 110

Tabela 12 - Resultado do ajuste por MQO robusto de acordo com a equação 3.7 sem as variáveis CONC e WEDGE . . . . . . . . . . . . . . . 131

Tabela 13 - Resultado do ajuste por MQO da equação 4.1 para $T E N U R E=1$. . . 131

Tabela 14 - Resultado do ajuste por MQO da equação 4.1 para $T E N U R E=2$. . . 132

Tabela 15 - Resultado do ajuste por MQO da equação 4.1 para $T E N U R E=3$. . . 132

Tabela 16 - Resultado do ajuste por MQO da equação 4.1 para $T E N U R E=4$. . . 132

Tabela 17 - Resultado do ajuste por MQO da equação 4.1 para $T E N U R E=5$. . . 133

Tabela 18 - Resultado do ajuste por MQO da equação 4.1 para $T E N U R E=6$. . . 133

Tabela 19 - Resultado do ajuste por MQO da equação 4.1 para $T E N U R E=7$. . 133 



\section{Lista de abreviaturas e siglas}

CVM Comissão de Valores Mobiliários

CMN Conselho Monetário Nacional

DFC Demonstração dos Fluxos de Caixa

DFP Demonstrações Financeiras Padronizadas

DOAR Demonstração das Origens e Aplicações de Recursos

EIC Entidades de Interesse Público

ERC Earnings Response Coefficients

GAO Government Accountability Office

IESBA International Ethics Standards Board for Accountants

PCAOB Public Company Accounting Oversight Board

SEC Securities and Exchange Commission 



\section{Sumário}

INTRODUÇÃO $\ldots \ldots \ldots \ldots \ldots \ldots \ldots$

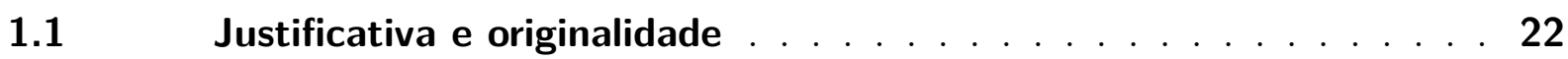

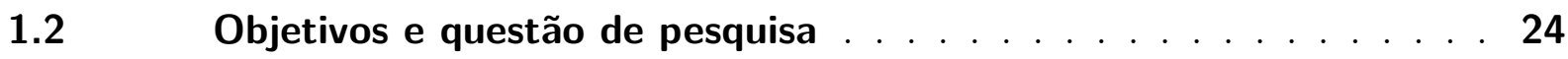

1.3 Divisão do trabalho . . . . . . . . . . . . . . . . . . . . . 24

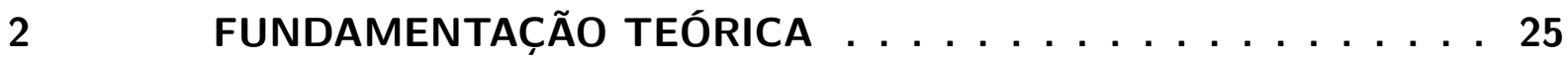

2.1 A informação contábil, seus principais problemas e o papel da auditoria 25

2.2 Qualidade das Auditorias . . . . . . . . . . . . 30

2.2 .1 Competência técnica . . . . . . . . . . . . . . . 31

2.2 .2 Independência. . . . . . . . . . . . . . . . . . . . 32

2.2.3 Métricas de mensuração da qualidade da auditoria . . . . . . . . . . . 34

2.3 O período de relacionamento auditor-auditado (audit tenure) e a qualidade de auditoria . . . . . . . . . . . . . . 41

2.3.1 Aplicação do rodízio mandatório de auditoria no mundo . . . . . . . . . 45

2.3.1.1 O rodízio de auditoria nos Estados Unidos . . . . . . . . . . . . . 48

2.3.1.2 O rodízio de auditoria na União Europeia . . . . . . . . . . . . . . . 49

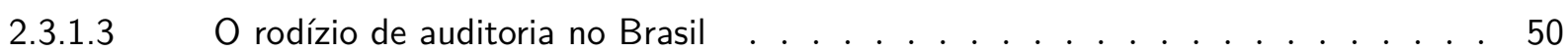

2.3.2 Estudos a respeito do rodízio mandatório de firmas de auditoria . . . . . 52

3 DESENHO E HIPÓTESES DE PESQUISA . . . . . . . . . 65

3.1 Algumas considerações sobre a modelagem da qualidade da auditoria 65

$3.2 \quad$ Modelo para o impacto da tenure . . . . . . . . . . . 66

3.2.1 Modelagem matemática . . . . . . . . . . . . . . . 68

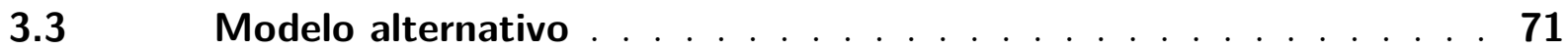

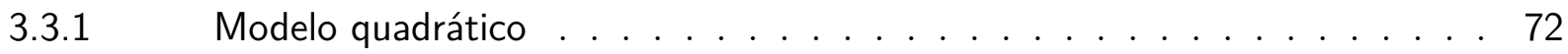

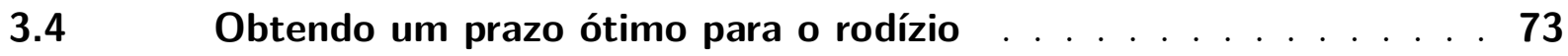

3.5 Operacionalização do modelo quadrático . . . . . . . . . . . 74

$3.6 \quad$ Hipóteses de pesquisa . . . . . . . . . . . . . . . . 77

4 ANÁLISE EMPÍRICA $\ldots \ldots \ldots \ldots \ldots \ldots$

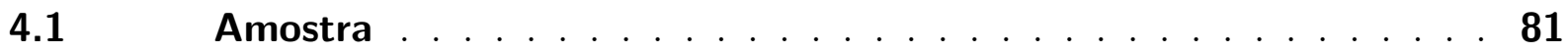

$4.2 \quad$ Resultados Principais $\ldots \ldots \ldots \ldots$

$4.3 \quad$ Testes de robustez $\ldots \ldots \ldots \ldots \ldots$

4.3.1 Accruals discricionários . . . . . . . . . . . . . . . . . 85

4.3.2 Variabilidade nos lucros líquidos . . . . . . . . . . . . 87 
Referências . . . . . . . . . . . . . . . . . 95

APÊNDICES

APÊNDICE A - RESUMO DA LITERATURA . . . . . . . . . . . 109

APÊNDICE B - QUESTIONÁRIO . . . . . . . . . . . . . . 121

APÊNDICE C - O PONTO PARA RODÍZIO DE FIRMA QUE MAXIMIZA A QUALIDADE MÉDIA DE AUDITORIA . . . . . . . . . . . . 127

APÊNDICE D - RESULTADOS DAS REGRESSÕES . . . . . . . . 131

D.1 Resultado da regressão do modelo básico sem as variáveis $C O N C$

e $W E D G E \ldots \ldots \ldots$

D.2 Resultados das regressões da variabilidade nos lucros líquidos . . . 131

APÊNDICE E - INTEGRAÇÃO NUMÉRICA PARA OBTENÇÃO

DA QUALIDADE MÉDIA . . . . . . . . . . . . . 135 


\section{Introdução}

A auditoria independente, considerada sob a perspectiva da Teoria da Agência, tem como função o monitoramento dos agentes da firma que atuam como prestadores de informações, visando a redução de custos de comportamento oportunista, ao prestar informações sobre as rupturas contratuais identificadas.

Nesse sentido, a auditoria independente só tem validade para os usuários das demonstrações financeiras quando é realizada por um terceiro com competência técnica e que tenha incentivos para reportar a realidade encontrada durante os procedimentos. Sendo assim, para que a auditoria seja considerada de qualidade é necessário que, simultaneamente, os auditores tenham competência técnica para a realização dos procedimentos e que tenham independência para reportar fidedignamente os resultados encontrados (DeAngelo, 1981b).

Órgãos reguladores de demonstrações financeiras estão sempre preocupados com o papel de monitoramento de firmas de auditoria. Por exemplo, a SEC (United States Securities and Exchange Commission) estabeleceu que os usuários de demonstrações financeiras devem ter confiança no trabalho realizado pelos auditores, e esse senso de confiança depende de uma razoável percepção dos investidores de que os auditores são profissionais independentes, que não têm nenhum interesse mútuo ou conflitante com seus clientes e que exercem julgamento objetivo e imparcial em todas as questões levadas a seu conhecimento (Hunt, 1997).

Diversos escândalos contábeis ocorreram num passado não remoto (por exemplo: Waste Management, Computer Associates, Xerox, Enron, Adelphia, Global Crossing, Tyco and WorldCom - Estados Unidos; Lernout \& Hauspie - Bélgica; OneTel - Austrália; Parmalat - Itália; Vivendi - França; Banco Nacional - Brasil; Bank of Credit and Commerce International - Reino Unido; National Kidney Foundation - Singapura; Royal Ahold Holanda; Anglo Irish Bank - Irlanda; Satyam Computer Services - Índia; Olympus Japão (Harris, 2012)), comprometendo justamente a independência dos auditores externos percebida pelos usuários dos mercados de capitais.

Assim, o rodízio mandatório de firmas de auditoria, que estabelece um limite para período de relacionamento auditor-auditado, passou a compor debates ao redor do globo, sendo considerado como um meio de preservar a independência do auditor e proporcionar maior confiança aos investidores. No entanto, não há consenso sobre sua efetividade, existindo diversos estudos que advogam contra o regime, bem como vários outros que o defendem.

A questão é bastante controversa, mas o debate sobre a desejabilidade desse regime é antigo e está longe de ser resolvido. Periodicamente o assunto ressurge nos documentos 
políticos que discutem a regulação da auditoria.

Nos Estados Unidos, a seção 207 da Lei Sarbanes-Oxley exigiu que o United States Government Accountability Office (GAO) conduzisse um estudo e revisasse os potenciais efeitos do rodízio mandatório de firmas de auditoria, que concluiu que não há claras evidências dos benefícios potenciais do regime (U.S. Government Accountability Office - GAO, 2003). Entretanto, mais recentemente, o PCAOB ${ }^{1}$ emitiu um concept release sobre "independência na auditoria e rodízio mandatório de firmas" (PCAOB, 2011), no qual o órgão solicitou comentários públicos sobre as vantagens e desvantagens do rodízio mandatório de firmas, considerando novamente a sua implementação, ainda que apenas por um período de teste.

Também em 2012, foram feitas audiências públicas sobre o assunto na Europa. A Comissão Europeia propôs o rodízio mandatório para todas as companhias listadas (Proposal for a Regulation of the European Parliament and of the council on specific requirements regarding statutory audits of public-interest entities, 2011), este regime foi aprovado em 2014 pela Regulation (EU) No 537/2014 of the European Parliament and of the Council (2014) e sua vigência se iniciou em 17 de junho de 2016.

A grande dificuldade para a realização de estudos conclusivos sobre o assunto é que, até pouco tempo, antes da recente adoção por parte dos membros da União Europeia, um número muito restrito de países adotavam o regime, de modo que a grande maioria dos estudos empíricos é realizada em ambientes cujo rodízio é opcional, ou seja, não conseguem reproduzir o ambiente que realmente se instalaria após sua implementação. Além disso, existe grande dificuldade em quantificar os benefícios do regime, de modo que os estudos acabam ficando mais focados nos custos. Outra questão é que os estudos existentes que analisam o período de relacionamento auditor-auditado, considerando a qualidade da auditoria como variável dependente, não separam os efeitos desse período de relacionamento nos dois componentes da qualidade da auditoria, independência e competência. O efeito do prazo na competência e na independência é oposto, quanto maior o período de relacionamento, maior se torna a competência do auditor (conhecimento sobre a firma auditada e sobre o seu negócio) e maiores são os prejuízos em termos de independência, e esses efeitos isolados não são evidenciados na maior parte dos modelos.

Apesar da controvérsia existente, o fato é que o rodízio mandatório de firmas de auditoria é mais uma ferramenta na tentativa de melhoria da segurança nas informações do mercado financeiro e, portanto, de redução do risco sistêmico de mercado. Assim, alguns países já optaram pela adoção dessa regra, como é o caso de Brasil, Índia, Itália, Singapura, Coréia do Sul, países da União Europeia (a partir de junho de 2016) e outros, vez por

1 O Public Company Accounting Oversight Board (PCAOB) é uma corporação sem fins lucrativos criada pelo Congresso norte americano para supervisionar as auditorias das empresas públicas, a fim de proteger os interesses dos investidores e promover o interesse do público na elaboração de relatórios de auditoria informativos, precisos e independentes. 
outra, discutem a possibilidade de sua implementação.

Nesse contexto, outra questão que surge com bastante importância é sobre o limite de períodos para o rodízio que deveria ser estabelecido pela regra, caso seja implementada. De acordo com o PCAOB (2011),

... vários limites de período para o rodízio mandatório de firmas de auditoria já foram sugeridos ao longo do tempo. O período de relacionamento auditor-auditado deveria ser uma variável chave em qualquer regra proposta. Um período muito longo poderia não elevar a independência num grau suficiente para fazer com que a regra valha a pena. Ao mesmo tempo, um período muito curto arriscaria a aumentar custos e causar perturbações desnecessárias. ${ }^{2}$

Uma das questões propostas pelo PCAOB (2011) em seu concept release foi justamente "se o Board determinasse avançar com o desenvolvimento da proposta de rodízio, qual deveria ser o prazo de relacionamento adequado?" 3

Nos países onde o regime é adotado, como é o caso do Brasil, o intervalo de tempo em que as firmas de auditoria são rodiziadas não é amparado por estudos científicos, sendo estabelecido sem considerar bases que poderiam levar a uma relação custo versus benefício mais adequada. Os diversos trabalhos existentes na literatura prendem seu foco no estudo da viabilidade da regra, sem contudo lançar luz sobre a questão tão relevante do prazo do rodízio. Na pesquisa realizada para o início desse trabalho, não foram encontrados estudos publicados que modelassem os determinantes de um prazo ideal para o regime. Apenas em 2017, identificamos o trabalho de Brooks, Cheng, Johnston, e Reichelt (2017), que buscou estimar um ponto "ótimo" para a substituição do auditor independente em diversos países que não utilizavam a regra de rodízio mandatório de firmas, considerando seus diferentes regimes legais de proteção ao investidor. Os modelos até então existentes não se ocuparam com a modelagem matemática embasada da relação do tempo de relacionamento auditor-auditado (tenure) com as vertentes da qualidade (competência e independência) tomadas de forma isolada. Diferente disso, a maioria dos trabalhos apresentam o efeito líquido da tenure na qualidade de auditoria e tratam essa relação como se fosse puramente linear, embora haja vários indícios científicos de que esse não é o caso.

A identificação de um prazo para a relação auditor-auditado que maximize a qualidade média da auditoria, para ser usado no rodízio mandatório de firmas, poderia viabilizar a implantação do regime em países que hora não o adotam, bem como fornecer subsídios para os órgãos normatizadores de países onde o regime já vigora, no intuito de melhorar o funcionamento da regra. Especificamente no caso do Brasil, país que já utiliza

2 ... various term lengths have been suggested at various times. The length of the term would be a key variable in any proposed rule. A term that is too long might not enhance independence to a sufficient degree to make the rule worthwhile. At the same time, a term that is too short risks increasing costs and causing unnecessary disruption (PCAOB, 2011).

3 If the Board determined to move forward with development of a rotation proposal, what would be an appropriate term length? (PCAOB, 2011). 
a regra desde 1999, mesmo com toda a pressão dos oponentes, o levantamento de um prazo "ótimo", no sentido de possibilitar a maior qualidade média de auditoria, ainda não foi tema de estudo.

Assim, a tese que se pretende investigar e eventualmente defender é que um prazo "ótimo" para o rodízio de firmas de auditoria no Brasil pode ser estimado. O pressuposto central é que, através de uma modelagem mais adequada dos impactos do tempo de relacionamento auditor-auditado na qualidade da auditoria, um período que resulte numa qualidade média de auditoria maximizada pode ser estimado. O levantamento desse prazo pode ajudar as autoridades a embasar a regra, mantendo sua função de redução dos problemas de independência, considerando ao mesmo tempo, a ampliação da qualidade média de auditoria e, com isso, diminuir os transtornos da sua aplicação.

\subsection{Justificativa e originalidade}

A análise mais detida sobre o prazo que deveria ser considerado caso um país opte pela adoção do regime mandatório de firmas de auditoria, tanto para países que já adotam a regra, quanto para os que estudam a possibilidade de adotar, revela ao menos quatro elementos relevantes em relação a sua importância e originalidade, a saber:

$1^{\circ}$ Considerando a importância da auditoria, destacando seu papel de intermediária informacional, as questões relacionadas à independência do auditor e, por conseguinte, à qualidade da auditoria de forma geral, é inerentemente relevante no contexto dos mercados de capitais. Por esta razão, observa-se um notório interesse na pesquisa acadêmica internacional acerca da auditoria independente, fato que pode ser confirmado através da Tabela 1, que resume as publicações sobre essa temática encontradas em alguns dos principais periódicos internacionais de notória reputação e visibilidade no campo da pesquisa contábil, no período de 2009 até o dia 5 do mês de setembro de 2017.

Tabela 1 - Publicações relacionadas à auditoria independente em periódicos selecionados.

\begin{tabular}{|l|c|c|c|c|c|c|c|c|c|}
\hline \multirow{2}{*}{ PERIÓDICO } & \multicolumn{9}{|c|}{ ANOS } \\
\cline { 2 - 11 } & 2009 & 2010 & 2011 & 2012 & 2013 & 2014 & 2015 & 2016 & 2017 \\
\hline International Journal of Auditing & 13 & 15 & 16 & 15 & 17 & 17 & 22 & 22 & 14 \\
\hline Accounting Horizons & 6 & 6 & 9 & 6 & 8 & 7 & 19 & 7 & 6 \\
\hline The Accounting Review & 8 & 14 & 9 & 9 & 15 & 13 & 21 & 15 & 9 \\
\hline Journal of Accounting and Economics & 2 & 4 & 2 & 5 & 1 & 5 & 1 & 7 & 4 \\
\hline TOTAL & 29 & 39 & 36 & 35 & 41 & 42 & 63 & 51 & 33 \\
\hline
\end{tabular}

Elaborado pela autora, com base no quadro de Braunbeck (2010).

$2^{\circ}$ Embora sejam inúmeros os trabalhos que tratam sobre o rodízio mandatório de firmas de auditoria, apresentando posições favoráveis e contrárias ao regime, é notável 
a escassez de trabalhos científicos em todo o mundo a respeito do prazo para esta regra operar e quais são os fatores determinantes deste prazo. Embora existam países que já implementaram tal regra, a implementação foi exercida sem base em estudo direto sobre a questão. O próprio PCAOB (2011), em seu Concept Release N²011-009, solicitou diretamente estudos sobre essa questão, visto não existirem pesquisas similares na bibliografia sobre a temática à época.

$3^{\circ}$ Diversos são os trabalhos que consideram os efeitos do período de relacionamento auditor-auditado (tenure) sobre a qualidade da auditoria (vide Tabela 11). No entanto, todos os trabalhos até então encontrados não segregam esses efeitos sobre a competência do auditor e sobre a sua independência, de forma isolada, tratando o efeito da tenure como um efeito único sobre a qualidade da auditoria. Essa forma de estudar a questão atrapalha a verificação de qual é maior, o efeito dos custos ou o efeitos dos benefícios, de um longo período de relacionamento auditor-auditado. É amplamente reconhecido na literatura que um longo período de relacionamento auditor-auditado, embora por uma via possa aumentar o conhecimento sobre um cliente específico e, por conseguinte, a competência, por outra pode aumentar a familiaridade do auditor com seu cliente, comprometendo então sua independência, fato que dá início ao debate sobre a possibilidade de implementação do rodízio de firmas. Com isto, considerações relativas à forma de modelagem segregada destes fatores são bem vindas.

$4^{\circ}$ Não foram encontrados na literatura trabalhos que tratem do prazo para o rodízio mandatório de firmas de auditoria no Brasil. No presente trabalho pretende-se desenvolver um modelo que seja capaz de estimar um prazo para o rodízio mandatório que maximize a qualidade média da auditoria. Além disso, apresenta-se considerações acerca da separação das contribuições do aumento da qualidade advindo do aumento da competência técnica e da redução da qualidade devido à perda de independência. Ademais, será feita a aplicação empírica ao Brasil, que é um país que adota o regime de rodízio mandatório. Isto traz contribuição à literatura, visto que a maioria dos trabalhos acadêmicos até então publicados não consideram estes fatores.

De forma geral, a principal justificativa para esse estudo é a ausência na literatura estudos semelhantes ao proposto para realidade brasileira, onde o rodízio mandatório de firmas de auditoria já vigora. Ademais, pretende-se também contribuir com as discussões acerca do tema apresentando considerações referentes à modelagem dos impactos da tenure na qualidade da auditoria. 


\subsection{Objetivos e questão de pesquisa}

Após as exposições anteriores, é razoável dizer que o objetivo dessa pesquisa é investigar se existe um prazo "ótimo" de duração do relacionamento auditor-auditado (tenure) no Brasil e determiná-lo, se possível, com vistas a maximizar a qualidade média da auditoria. Mais especificamente, pretende-se desenvolver um modelo que considere os efeitos da tenure sobre a qualidade da auditoria, destacando de forma separada seus efeitos sobre a competência do auditor e sobre a sua independência. Em um segundo momento, pretendese realizar a aplicação empírica desse modelo, com algumas simplificações, às companhias abertas do mercado brasileiro, visando oferecer um número de anos de relacionamento auditor-auditado que sirva como base para a regra de rodízio mandatório de firmas de auditoria no Brasil. Ressalta-se neste ponto, que este trabalho não visa discutir a necessidade, os benefícios e os problemas relacionados à regra de rodízio mandatório de firmas de auditoria. Busca-se, simplesmente, considerar qual seria o prazo mais adequado num cenário onde a regra é aplicada.

Assim, o problema de pesquisa que se pretende resolver é: qual é o prazo "ótimo", se houver, de duração do relacionamento auditor-auditado (tenure) no Brasil para se obter o máximo de qualidade média de auditoria?

\subsection{Divisão do trabalho}

Este trabalho contém, além dessa introdução, o capítulo 2, destinado à apresentação dos fundamentos teóricos que dão sustentação ao estudo proposto. No capítulo 3 é apresentado o modelo desnvolvido e sua adaptação para a aplicação empírica. A análise empírica e seus desdobramentos são tratados no capítulo 4. Por fim, no capítulo 5, são apresentadas as conclusões e perspectivas do trabalho. 


\section{Fundamentação Teórica}

Neste capítulo procura-se estruturar a plataforma teórica que dá suporte ao modelo que será discutido no capítulo 3, cujo objetivo será fornecer bases para respostas ao problema de pesquisa explicitado no capítulo 1 desta tese.

\subsection{A informação contábil, seus principais problemas sob a pers- pectiva da Teoria da Agência e o papel da auditoria}

A microeconomia clássica constrói suas análises partindo da premissa de que todos os agentes econômicos existentes no mercado detêm informação "perfeita" nas transações que executam. Esse pressuposto de informação completa é alicerçado sobre a suposição de que não existem custos para acesso às informações.

No entanto, essa situação não é a que se observa na realidade, o que levou autores como Jensen e Meckling (1976) a relaxarem a premissa de informação "perfeita", buscando explorar os mecanismos de mercado na presença de informações assimétricas entre os agentes econômicos.

Jensen e Meckling (1976) desenvolveram a Teoria da Agência (também conhecida como Teoria do Agente-Principal), com raízes no utilitarismo econômico (Ross, 1973) e cuja premissa básica é a existência de um mercado regido por contratos firmados entre os agentes econômicos, incluindo empresas, governos ou pessoas físicas. Assim, toda a atividade econômica pode ser reduzida a uma série de contratos que podem ser firmados ou rompidos a qualquer momento por qualquer uma das partes. Nesse sentido, a Teoria da Agência apoia-se fundamentalmente em quatro pressupostos (Jensen \& Meckling, 1976):

a) os indivíduos buscam maximizar sua função-utilidade;

b) as firmas são organizações que agregam diferentes interesses e, por sua vez, assumem custos e benefícios conforme especificações contratuais, implícita ou explicitamente definidas entre as partes;

c) em decorrência de (a) e (b), o comportamento dos indivíduos dentro das organizações dependerá fundamentalmente da natureza dos contratos;

d) em cada contrato haverá um principal que demanda ao agente um determinado "produto" e, para tanto, o principal delega ao agente direitos e poderes, recebendo esse último algum tipo de benefício ou contraprestação pela ação executada. 
A questão central dessa teoria está no relacionamento entre agente e principal, em que o principal contrata o agente para atuar buscando a consecução de seus objetivos. O agente dispõe de informações privilegiadas e suas ações afetam o bem estar entre as partes, sendo dificilmente observáveis pelo principal. Esse relacionamento traz consigo dificuldades que podem surgir em função de condições de informação assimétrica e incompleta, que beneficia o agente em detrimento do principal (Eisenhardt, 1989; Jensen \& Meckling, 1976).

A Teoria da Agência estuda, então, como um ator econômico (principal) estabelece um sistema de compensação (contrato) que motive a outra parte (agente) a agir de acordo com seus interesses. A grande questão é a dificuldade de monitorar o esforço e os incentivos dos atores econômicos envolvidos em uma transação, dificultando ainda mais a elaboração de contratos (Lima, Araújo, \& Amaral, 2008). Sendo assim, são incluídos sistemas de incentivos baseados na performance observada, onde as partes envolvidas enfrentam o trade off entre incentivos ótimos e repartição ótima de riscos (Jensen \& Meckling, 1976).

Dois problemas básicos derivam da análise de contratos proposta por essa teoria, a saber, a seleção adversa e o risco moral. O problema de seleção adversa ocorre quando um indivíduo conhece suas próprias características, mas outros indivíduos não participam dessa informação privada. A seleção adversa decorre do custo de acesso à informação, o que faz com que a seleção do produto a ser demandado ocorra de forma ineficiente (adversa), em função da assimetria de informação entre os ofertantes e os demandantes (Carvalho, Souza, Sicsú, Paula, \& Studart, 2002). Akerlof (1970) apresentou um clássico exemplo na literatura de seleção adversa, o do mercado de automóveis usados nos Estados Unidos, em que, em condições de assimetria de informações acerca da qualidade dos veículos (se tratam-se de bons veículos ou de "limões", assim entendidos os carros de baixa qualidade), os carros de pior qualidade deslocam do mercado os carros de qualidade superior, a um dado preço médio. Daí, resulta que em condições de assimetria informacional se manifesta uma falha de mercado, resultante de externalidades entre os vendedores de bons carros e de carros de qualidade inferior.

Já o risco moral decorre da não convergência entre as funções-utilidade do agente e do principal (participantes de um contrato), o que cria incentivos para que o agente exproprie o principal. Tirole (2006, p. 16) apresenta quatro formas de atuação do agente em desacordo com os interesses do principal, a saber: (a) esforço insuficiente; (b) investimentos "extravagantes"; (c) estratégias de "entrincheiramento"; e (d) negociações em benefício próprio. Um exemplo típico de risco moral é o que se observa na indústria de seguros, em que diferentes consumidores que contratam os seguros apresentam distintos comportamentos quanto ao cuidado com o bem segurado, fato que modifica a probabilidade de ocorrência de sinistros entre eles.

Considerando os problemas de agência apresentados, Jensen e Meckling (1976) 
propõem, então, a existência de custos de agência, que são custos incorridos com o objetivo de fazer com que as decisões do agente sejam ótimas sob a perspectiva do principal. Os custos apresentados por esses autores são a somatória de:

a) despesas de monitoramento (monitoring expenditures): despesas incorridas pelo principal em um esforço de evitar o comportamento oportunista do agente. De acordo com Braunbeck (2010), aqui se incluem auditorias, sistemas de controle interno, restrições orçamentárias e o estabelecimento de sistemas de remuneração variável do executivo, todos visando o alinhamento das funções-utilidade do agente e do principal;

b) despesas de comprometimento do agente (bonding expenditures): despesas incorridas com o propósito de criar proteção contra eventuais danos causados pelo agente;

c) perdas residuais (residual losses): perdas que o principal não conseguiu evitar através do monitoramento e dos mecanismos de comprometimento do agente.

Atuando também no sentido de contornar os problemas decorrentes dos conflitos de agência, Akerlof (1970) destaca que inúmeras instituições podem ser utilizadas para fazer frente aos efeitos da incerteza provocada pela assimetria de informações, mencionando garantias (branding) e licenciamento (ex: exame do Conselho Federal de Contabilidade para os bacharéis em ciências contábeis atuarem no Brasil).

De acordo com Braunbeck (2010), os paralelos dos problemas da Teoria da Agência com o mercado de capitais, ou ainda com o mercado de dívidas, são bastante intuitivos. Os valores mobiliários são os valores transacionados, cujos preços deveriam refletir a avaliação dos compradores e suas expectativas de benefícios econômicos na forma de caixa a valor presente (Assaf Neto, 2009, p.645). A questão é que, assim como no exemplo do mercado de veículos proposto por Akerlof (1970), em que há assimetria de informações acerca da qualidade dos carros, no mercado mobiliário os investidores também não conhecem a empresa tão bem como seus gestores. Nesse contexto, é razoável supor, por exemplo, que nem sempre os acionistas controladores atuarão no melhor interesse dos acionistas não controladores, conflito esse muito sensível, por exemplo, na realidade brasileira. Conforme ressalta Gorga (2005), tem-se no ambiente societário brasileiro, caracterizado por forte concentração de capital, decisões ineficientes que são tomadas pelos controladores, através das quais esses extraem vantagens ou benefícios privados do controle, expropriando de certa forma os acionistas minoritários.

A literatura contempla ainda uma gama de trabalhos que descrevem meios através dos quais gestores, movidos por seus próprios interesses, expropriam outras partes dentro da organização. Em um cenário de imperfeições nos contratos e no monitoramento, gestores têm incentivos para, de forma oportunista, reportar lucros que maximizem a utilidade 
do seu contrato de trabalho, (Harris, 2012). Evidências empíricas comprovam esse tipo de comportamento. Em seu trabalho, Yermack (1997) apontou que os gerentes recebem outorgas de opção de ações (stock option grants) pouco antes do anúncio de boas notícias e atrasam tais outorgas para depois do anúncio de más notícias, usando o timing das outorgas de compra de ações como mecanismos para auto-negociação. Gerentes também podem se valer do poder discricionário que exercem sobre a contabilidade para criar reservas durante anos de bom desempenho, fazendo com que os lucros correntes e futuros pareçam menos variáveis, gerenciando resultados. Healy (1985) e Holthausen, Larcker, e Sloan (1995) apresentaram evidências de que firmas com limites para concessão de bônus são mais propensas a adiar o faturamento quando esse bônus máximo é atingido, do que as empresas que têm um desempenho comparável, mas que não têm limite de bônus. Adicionalmente, Lie (2005) e Edelson e Whisenant (2012) apresentaram duas técnicas alternativas de detecção para identificar antecipações de opções de ações (stock options) por gerentes corporativos, ambos indicando que essa prática é muito difundida e resulta em substancial transferência de riqueza dos acionistas para os gestores da entidade.

Como já foi destacado, instituições são utilizadas para tentar minimizar esses problemas, dentre as quais pode ser citada a imposição de termos mínimos para a entidade que vai ao mercado captar recursos, em que se inclui, por exemplo, a obrigatoriedade de divulgação de informações sobre a performance passada (em geral, auditadas), assim como informações sobre mercados, riscos e estratégias, nos prospectos das ofertas públicas de ações (Hertig, Kraakman, \& Rock, 2004, p. 197).

Considerando todo esse contexto dentro da Teoria Contratual da Firma, a contabilidade cumpre o papel de mensurar a contribuição, o resultado e a parcela de cada participante no valor da empresa e dos seus respectivos contratos, além de distribuir informações para outros potenciais participantes (Lopes \& Martins, 2005). Assim, a contabilidade tem potencial para reduzir os problemas decorrentes da assimetria informacional e de oferecer subsídios para o alinhamento de interesses entre gestores e proprietários através da remuneração dos executivos com base no desempenho da firma, mensurado pela contabilidade (Braunbeck, 2010).

Além das possíveis soluções já mencionadas para os problemas de agência, intermediários informacionais (por exemplo, analistas de mercado, agências de classificação, mídia especializada e auditores independentes) podem auxiliar na redução de problemas de assimetria informacional e conflito. De acordo com Braunbeck (2010), esses intermediários atuam no sentido de "divulgar" informação privada dos insiders, quanto ao problema de agência, uma vez que permitem o monitoramento das tentativas dos agentes de expropriar os principais.

Nesse sentido, na busca pela alocação eficiente dos recursos no mercado de capitais, os intermediários informacionais atuam no fluxo de informações, com vistas a reduzir 
a assimetria informacional e mitigar os custos de agência. Os auditores independentes integram essa categoria de intermediários de informação. Semelhante a um mecânico de confiança na aquisição de um veículo usado no exemplo do mercado de automóveis usados proposto por Akerlof (1970), os auditores independentes seriam uma espécie de intermediários informacionais de confiança, no sentido de fornecerem atestados de fidedignidade das demonstrações contábeis, operando em condições de assimetria informacional e conflito de agência (Lopes \& Martins, 2005).

Watts e Zimmerman (1983) possivelmente foram os primeiros autores a explicitamente buscarem explicar e prever a prática de auditoria dentro do contexto da Teoria da Firma proposta por Jensen e Meckling (1976). Em seu trabalho, esses autores procuraram organizar algumas evidências históricas da prática da auditoria sob a perspectiva do problema de agência, partindo da visão de que os contratos dentro da firma são estabelecidos com vistas a reduzir o oportunismo dos agentes e que o enforcement desses contratos requer o monitoramento do agente, onde, então, a auditoria encontra seu papel.

Nesse sentido, uma auditoria logrará êxito se for capaz de reduzir os custos do comportamento oportunista, prestando informação sob as rupturas contratuais que identificar. Watts e Zimmerman (1983) definem, então, independência do auditor como a probabilidade de que o auditor venha a informar uma ruptura contratual identificada e afirmam que a auditoria somente será capaz de reduzir os custos de agência se o mercado perceber o auditor como independente.

Assim, esses autores constroem sua hipótese de que a prática contábil da auditoria é explicada sob a perspectiva da Teoria da Agência, de que indivíduos são maximizadores de sua utilidade, e não sob a perspectiva de que a auditoria independente é fruto da legislação societária. Desta forma, Watts e Zimmerman (1983) corroboram essa hipótese através de evidências históricas em que se observa, por exemplo, a prática da auditoria antes das leis societárias (em 1346) nas guildas inglesas, que congregavam comerciantes bem sucedidos na forma de cartel. Os membros dessas entidades (comerciantes e proprietários) dispunham de interesses conflitantes aos de seus "gestores", de modo que as contas elaboradas pelos "gestores" eram revisadas detalhadamente por "auditores", existindo inclusive evidências de situações em que esses teriam se negado a certificar as contas ou que desautorizaram registros em razão de irregularidades detectadas. Nesse cenário histórico, o que incentivava a independência do auditor era a imposição de multas no não cumprimento dos prazos pelo auditor ou o impacto de uma auditoria de qualidade duvidável em termos de reputação e, em casos extremos, até mesmo a expulsão do auditor da guilda e, por consequência, perda de suas propriedades na guilda.

Em um trabalho posterior (Positive Accounting Theory), esses mesmos autores dedicaram um capítulo para explorar a aplicação da Teoria Positiva à auditoria, avançando na abordagem de seu trabalho de 1983. Watts e Zimmerman (1986, p. 314) partem da 
premissa de que uma auditoria terá valor para os usuários das demonstrações contábeis somente se esses usuários entenderem que a probabilidade de que o auditor reporte uma quebra contratual é não nula. Ou seja, haverá demanda por auditoria se o auditor for percebido como independente.

Assim, esses autores partem da vista de DeAngelo (1981b) e definem que a probabilidade de um auditor informar uma quebra contratual, depende:

a) da probabilidade do auditor descobrir a desconformidade existente (o que depende da competência técnica do auditor e dos recursos disponíveis para a auditoria); e

b) da probabilidade do auditor reportar a desconformidade descoberta (independência do auditor).

Assim, as firmas compreendem nexos contratuais, que englobam interesses divergentes de indivíduos cujas funções-utilidade, pelo menos inicialmente, não convergem e que não possuem acesso simétrico às informações. Nesse contexto, a informação contábil assume o papel de reduzir essa assimetria informacional entre as partes, embora também apresente falhas, pois ela própria é vítima do conflito existente nas relações contratuais, pois tais conflitos impactam inclusive a informação produzida para regular os contratos. Os preparadores das informações contábeis são eles próprios detentores de acesso privilegiado para gerá-las e pertencem à constelação de contratos (Braunbeck, 2010). "Essa dupla capacidade dos executivos e homens de negócio de serem agentes a serem monitorados e responsáveis de fato pela preparação da contabilidade, reduz o valor desta perante terceiros" 1 (Arruñada, 2000).

\subsection{Qualidade das Auditorias}

DeAngelo (1981b) define a qualidade da auditoria como a probabilidade conjunta avaliada pelo mercado, de que um determinado auditor descubra uma possível distorção no sistema de contabilidade do cliente e que revele tal distorção. Pode-se dizer então que a qualidade da auditoria é uma função da competência do auditor (capacidade do auditor de detectar omissões materiais ou distorções nas demonstrações contábeis do cliente) e do nível de ameaças reais à independência do auditor (a probabilidade do auditor revelar distorções materiais que vier a detectar) (Harris, 2012). A variação nos aspectos relacionados à detecção de falhas representa a variação no nível de competência do auditor (ou da firma de auditoria), enquanto que a variação nos incentivos para reportar tais falhas representa o nível de independência do auditor (ou da firma de auditoria). A

1 "This dual capacity of executives and businessmen as agents to be monitored and as those responsible for actually preparing the accounts reduce the value of the latter to third parties" (Arruñada, 2000). 
auditoria, bem como o relatório do auditor, devem ser realizados e preparados com o devido zelo profissional por pessoas que têm adequado treinamento (formação) e competência técnica (American Institute of Certified Public Accountants (AICPA), 1985). A falta de competência, proveniente da falta de conhecimento e de experiência, pode fazer com que o auditor tenha que confiar no gerenciamento do cliente, em termos de fazer questionamentos e acessar respostas, aumentando sua dependência (Lee \& Stone, 1995). Feitas as considerações acima, a melhoria nos níveis de competência e/ou de independência, resulta em melhoria no nível de qualidade da auditoria. Da mesma forma, uma deterioração em qualquer um desses dois níveis, também levaria a uma deterioração na qualidade da auditoria.

Matematicamente, a qualidade das auditorias (QA) pode ser assim representada:

$$
Q A=f(\text { Competência, Independência }) \text {. }
$$

A seguir, está apresentada uma breve revisão sobre as dimensões que compõem a qualidade da auditoria: competência e independência.

\subsubsection{Competência técnica}

De acordo com DeAngelo (1981b, p.186), ao se falar de competência técnica no contexto da qualidade das auditorias, há que se considerar que a detecção de falhas no sistema contábil da entidade auditada depende, além das habilidades técnicas do auditor, da tecnologia empregada na execução da auditoria, dos procedimentos realizados pelo auditor, da extensão de seus exames, dentre outros. Carson (2009, p. 358) complementa esses fatores, apontando também o grau de especialização e o treinamento das equipes de auditoria num determinado setor e Watkins, Hillison, e Morecroft (2004, p. 166) citam ainda o desenvolvimento e aplicação de sistemas e metodologias de auditoria.

Watkins et al. (2004) apontam que os incentivos para que a competência técnica seja observada no desenvolvimento das auditorias podem ser classificados como provenientes tanto da demanda, quanto da oferta por serviços de auditoria. A demanda por auditores competentes será determinada pela estratégia de gestão de riscos do cliente auditado e pelos conflitos de agência. Enquanto a oferta será determinada por fatores relacionados aos honorários, bem como ao gerenciamento de riscos da firma de auditoria.

Considerando a abordagem da demanda por competência técnica nas auditorias (demanda por qualidade das auditorias), Titman e Trueman (1986) construíram um modelo que dá suporte teórico à conclusão de que o valor da firma é uma função crescente da qualidade do auditor, logo, sob essa perspectiva, seria razoável supor que existem incentivos para que a firma contrate auditores competentes, uma vez que isso teria impacto favorável na avaliação econômica da entidade. Almutairi, Dunn, e Skantz (2009) apresentaram evidência empírica compatível com esse desenvolvimento ao estudar a relação entre o 
bid-ask spread ${ }^{2}$ de uma empresa (uma proxy de assimetria de informação), o período de relacionamento auditor-auditado e a especialização do auditor, sendo que seus resultados demonstram que a escolha de um auditor especialista (tecnicamente, mais competente) pode ajudar a reduzir a assimetria de informação, o que é valorizado pelo mercado.

Em termos de incentivos para oferta de auditorias realizadas com maior competência técnica, Carson (2009) identifica que auditores especialistas recebem prêmios em seus honorários, o que constitui um incentivo para que os auditores procurem aumentar sua qualificação.

Braunbeck (2010), através da análise da participação de mercado do auditor num determinado segmento da indústria também aponta, dentre outras coisas, que auditores com maior especialização estão associados a auditorias de maior qualidade, o que, conforme observado nos outros estudos, pode contribuir tanto na melhoria do valor da firma, quanto para o incremento dos honorários, representando incentivo à competência técnica tanto pelo lado da demanda, quanto pelo lado da oferta. Assim como Braunbeck (2010), autores como Gul, Fung, e Jaggi (2009), Krishnam (2003) e Balsam, Krishnam, e Yang (2003), também apresentaram resultados sugerindo que, de modo geral, os auditores especialistas estão associados a informações contábeis de maior qualidade.

\subsubsection{Independência}

A independência é uma importante questão quando se avalia a credibilidade da opinião apresentada no relatório do auditor, tendo, portanto, diversas implicações. A primeira delas é de natureza política, visto que a independência do auditor tem o poder melhorar a credibilidade dos relatórios financeiros publicados e, desse modo, adicionar valor para várias partes interessadas (stakeholders). A segunda implicação está diretamente relacionada à profissão, pois a característica de independência é o melhor caminho para demonstrar ao público e ao regulador que os auditores estão exercendo suas funções de acordo com os princípios éticos, com objetividade e com integridade, sendo que a objetividade é o meio pelo qual o auditor suprime vieses, e a integridade implica que o auditor expresse uma opinião que reflita de fato o que ele descobriu durante a auditoria (Cameran, Di Vincenzo, \& Merlotit, 2005).

A independência do auditor não é um padrão rígido e absoluto a ser cumprido, não é livre de influências econômicas, financeiras e outros relacionamentos que possam ocasionar a dependência do auditor. O julgamento da independência deve considerar as circunstâncias específicas no cenário em que o auditor opera (Cameran et al., 2005).

O parágrafo 290.6 do Código de Ética do International Ethics Standards Board for

$2 \quad$ Bid-ask spread trata-se do montante em que o preço de venda excede o lance. Esta é essencialmente a diferença de preço entre o preço mais alto que um comprador está disposto a pagar por um ativo e o menor preço pelo qual um vendedor está disposto a vendê-lo. 
Accountants (IESBA) (2014) explica que a independência compreende não só independência de mente, mas também independência de aparência. Em relação à independência de mente, diz que é o estado mental que permite a elaboração de uma opinião sem ser afetada por influências que comprometam o julgamento profissional, permitindo por este meio que um profissional atue com integridade e tenha objetividade e ceticismo profissional. Já a independência de aparência, compreende a necessidade de se evitar fatos e circunstâncias que são tão significativos a ponto de que um terceiro informado seja susceptível a concluir que, pesando todos os fatores e circunstâncias específicas, a integridade, a objetividade e o ceticismo profissional de uma firma, ou de um membro de uma equipe de auditoria, tenham sido comprometidos.

Pesquisas existentes demonstram que quando a percepção da qualidade da auditoria é comprometida por possível redução da independência, o mercado de capital sofre consequências negativas. Isto pode ser visto, por exemplo, nos trabalhos de Francis e Ke (2006) e Frankel, Johnson, e Nelson (2002).

Arruñada (1997) dedica um capítulo de seu trabalho para discutir os determinantes econômicos que pesam sobre a independência do auditor ao buscar compreender as "forças" econômicas que atuam sobre a decisão do auditor em modificar ou não sua opinião diante de uma falha identificada. Esse autor constrói um modelo em que variáveis como (i) as quase rendas ${ }^{3}$ associadas a um cliente específico para o qual o auditor identifique uma falha material; (ii) os ativos específicos relativos aos demais clientes da firma de auditoria (por exemplo, as quase rendas dos demais clientes); (iii) os ativos específicos à firma de auditoria como um todo (como exemplo, sua metodologia, sua especialidade e conhecimentos acumulados), cujo valor depende de sua continuidade; (iv) o valor presente das contingências por responsabilidade profissional (exemplo, custo presente dos litígios possíveis); e (v) o valor líquido da firma de auditoria para seus sócios; determinam se o auditor será independente ou não e, consequentemente, influenciam a qualidade da auditoria. Decorrente da análise de seu modelo, esse autor entende que é razoável supor que, caso as perdas associadas à perda de um cliente específico sejam menores que as perdas decorrentes do seu envolvimento num "escândalo" contábil de um cliente que se apresente com problemas financeiros, o auditor possui incentivos econômicos para reportar as falhas detectadas, ou seja, ser independente.

Considerando a importância da independência para a qualidade da auditoria, diversos mecanismos de manutenção são propostos na literatura e pelos reguladores ao redor do mundo. Esses mecanismos incluem, entre outros, padrões de controle de qualidade das auditorias (por exemplo, revisão pelos pares), uso de forças de mercado (custos de litígio e perda de reputação), aplicações de multas e penalidades, duas auditorias simultâneas,

3 De acordo com DeAngelo (1981b, p.116), quase rendas correspondem ao excedente de receitas sobre os custos evitáveis, incluindo o custo de oportunidade de auditar o melhor cliente alternativo. 
comitês de auditoria ${ }^{4}$, proibição de prestação simultânea de serviços de não auditoria e de auditoria, rodízio de sócios de auditoria e rodízio de firmas de auditoria (Cameran et al., 2005).

Quanto ao rodízio de firmas de auditoria, esse mecanismo de manutenção da independência vem sendo adotado por alguns países e considerado por vários outros sob a prerrogativa de que um longo período de relacionamento auditor-auditado pode aumentar a probabilidade de que ocorra um vínculo econômico que ameace a objetividade do auditor na sua função de monitoramento (Harris, 2012). Mais detalhes sobre essa regra são discutidos em seções a seguir.

\subsubsection{Métricas de mensuração da qualidade da auditoria}

Nas ciências sociais, frequentemente, as variáveis de estudo são abordadas dentro de uma perspectiva teórica sem, contudo, serem diretamente observáveis. Nesse cenário, cabe ao pesquisador que pretende testar hipóteses a partir da teoria, desenvolver construtos que sejam operacionalizáveis no teste empírico (Braunbeck, 2010). Para tanto, é necessário eleger aspectos observáveis que possam representar, ainda que imperfeita ou incompletamente, a variável de estudo, são as chamadas proxies.

Para medir a qualidade da auditoria, pesquisadores ao redor do mundo se valem, principalmente, de métricas baseadas em informações contábeis, métricas baseadas em informações de mercado e em métricas baseadas em informações resultantes do próprio processo de auditoria. Abaixo está apresentada uma breve descrição de cada um desses tipos de métricas.

\section{(i) Métricas baseadas em informações contábeis}

As métricas baseadas em informações contábeis se assentam, sobretudo, na ideia subjacente de que a qualidade da informação contábil (earning quality) está positivamente relacionada à qualidade da auditoria, ou seja, quanto maior a qualidade de uma auditoria, maior será a qualidade da informação contábil. Nessa linha, a principal associação que se encontra na literatura é entre a qualidade da auditoria e o gerenciamento de resultados. As proxies mais comumente usadas pelos pesquisadores da área são o erro de projeção de resultados (ex: desvio entre o resultado projetado e o resultado contábil auditado), como é o caso do trabalho de Davidson e Neu (1993), e os accruals discricionários (considerando que a discricionariedade dá "margem" para o gerenciamento de resultados, de modo que quanto maior seu nível, pior a qualidade da auditoria), vastamente utilizados na literatura, inclusive por Jones (1991), Kang e Sivaramakrishnan (1995), Dechow, Sloan, e Sweeney

4 Por exemplo, Dao, HassabElnaby, e Said (2015) fizeram um estudo cujos resultados indicam que as empresas podem reduzir o efeito de longos contratos de auditorias e, portanto, reduzir os problemas de independência, quando têm comitê de auditoria com membros mais experientes. 
(1995), DeFond e Subramanyam (1998), Krishnam (2003), Myers, Myers, e Omer (2003), Francis e Yu (2009), Almeida e Almeida (2009), Lennox, Wu, e Zhang (2016), Postma (2016), Brooks et al. (2017) e muitos outros.

Os modelos de accruals discricionários nos estudos de gerenciamento de resultados foi o que deu grande impulso para a utilização de medidas contábeis em auditoria, sobretudo a partir do trabalho pioneiro de Jones (1991). Versões posteriores do modelo trouxeram modificações, buscando sempre aumentar sua eficácia, porém utilizando-se das mesmas bases, ou seja, accruals discricionários como proxy de gerenciamento de resultados. Exemplos desse modelos são o modelo Jones modificado de Dechow et al. (1995), o modelo KS de Kang e Sivaramakrishnan (1995), o modelo de DeFond e Park (2001), o modelo de Francis e Wang (2008) e outros mais.

Especificamente, o modelo de Francis e Wang (2008), adaptado de DeFond e Park (2001) para medir accruals anormais, pode ser descrito como segue:

$$
\begin{aligned}
& \operatorname{PredAcc}_{i, t}=\operatorname{Sale}_{i, t}\left(\frac{W C A_{i, t-1}}{\text { Sale }_{i, t-1}}\right)-P P E_{i, t}\left(\frac{D e p_{i, t-1}}{P P E_{i, t-1}}\right), \\
& W C A_{i, t}=\Delta\left[\text { Act }_{i, t}-C h e_{i, t}\right]-\Delta\left[\operatorname{Lct}_{i, t}-\operatorname{Dlc}_{i, t}-\operatorname{Prodv}_{i, t}\right], \\
& A b A c c_{i, t}=\frac{\operatorname{Pred} A c c_{i, t}-T A C C_{i, t}}{\text { Asset }_{i, t-1}},
\end{aligned}
$$

onde:

- PredAcc $c_{i, t}$ : accruals previstos para a firma $i$ no ano $t$;

- Sale $e_{i, t}$ : receita de vendas da firma $i$ no ano $t$;

- $W C A_{i, t}$ : variação no capital de giro não monetário da firma $i$ do ano $t-1$ ao ano $t$;

- $A c t_{i, t}$ : total de ativos circulantes da firma $i$ no ano $t$;

- $C h e_{i, t}$ : caixa e investimentos de curto prazo da firma $i$ no ano $t$;

- Lct $_{i, t}$ : total de passivos circulantes da firma $i$ no ano $t$;

- $D l c_{i, t}$ : montante total da dívida no passivo circulante da firma $i$ no ano $t$;

- $\operatorname{Prodv} v_{i, t}$ : dividendos propostos pela firma $i$ no ano $t$.

- $P P E_{i, t}$ : valor bruto do imobilizado da firma $i$ no ano $t$;

- $D e p_{i, t-1}$ : despesas de depreciação da firma $i$ no ano $t-1$;

- Assets $_{i, t}$ : total de ativos da firma $i$ no ano $t$; 
- $T A C C_{i, t}$ : total de accruals da firma $i$ no ano $t$, calculado como o lucro líquido menos os fluxos de caixa operacionais ${ }^{5}$;

- $A b A c c_{i, t}$ : accruals anormais para a firma $i$ no ano $t$, isto é, accruals previstos (PredAcc) menos o total de accruals $(T A C C)$, ponderado pelos ativos do ano $t-1$.

Como se pode observar, esse modelo usa o índice de acumulação de capital de giro $(W C A)$ e o índice de depreciação $(D e p)$ defasados para estimar os accruals previstos (PredAcc). O principal pressuposto desse modelo é que esses índices defasados específicos da empresa devem persistir por um 1 ano. Diferentemente do modelo de Jones (1991), esse modelo considera as diferenças específicas das firmas, uma vez que não apura os accruals com base na média de todas as firmas, como ocorre quando se usa resíduos de regressão no modelo de Jones (1991) e similares. Além disso, uma outra vantagem desse modelo, frente ao modelo de Jones (1991) e seus similares, é que ele requer apenas 1 ano de dados anteriores, não necessitando de um grande número de observações ${ }^{6}$. O negativo do valor absoluto de $A b A c c_{i, t}$ pode ser utilizado como métrica de qualidade de auditoria, evidenciando um melhor nível de qualidade para menores magnitudes de accruals anormais, conforme Brooks et al. (2017).

Ainda na linha de pesquisa que relaciona qualidade da auditoria e gerenciamento de resultados, Harris (2012) desenvolveu um trabalho se valendo de várias métricas de discricionariedade potencial em resultados (por exemplo, alisamento de resultados, reconhecimento oportuno de perdas, metas de pequenos lucros) para verificar se a qualidade da auditoria aumentou após a adoção da regra de rodízio mandatório de firmas de auditoria em alguns países. Uma das métricas utilizadas para verificar suavização de resultados foi a variabilidade nos lucros líquidos. Essa métrica foi operacionalizada através da regressão da variação do lucro líquido anual (ponderado pelo ativo total) contra variáveis de controle identificadas em pesquisas anteriores (Ashbaugh (2001), Pagano, Röell, e Zechner (2002), Lang, Raedy, e Yetman (2003), Tarca (2004), Lang, Raedy, e Wilson (2006)), de acordo com a equação 2.5. A variância dos resíduos dessa equação foi considerada como indicador da variabilidade do resultado em cada situação analisada.

$$
\begin{aligned}
\Delta N I_{i, t} & =\beta_{0}+\beta_{1} S I Z E_{i, t-1}+\beta_{2} G R O W T H_{i, t}+\beta_{3} E I S S U E_{i, t}+\beta_{4} L E V_{H i, t} \\
& +\beta_{5} \text { DISSUE } E_{i, t}+\beta_{6} A_{T O} O_{i, t}+\beta_{7} C F O_{i, t}+\beta_{8} B I G N_{i, t}+e_{i, t},
\end{aligned}
$$

5 Foram utilizados os fluxos de caixa operacionais extraídos da DFC, quando disponível. Quando não disponível, essa informação foi calculada através dos dados da DOAR

6 Os accruals anormais do modelo de Francis e Wang (2008) são calculados com base nas equações 2.2, 2.3 e 2.4, precisando apenas dos dados vigentes e dos dados do período anterior de uma dada empresa, ou seja, os accruals anormais de determinada empresa não estão condicionados aos dados de outras empresas e de outros períodos. Já os accruals discricionários do modelo de Jones (1991) e de seus similares, são calculados com base no resíduo de regressão, o que implica a necessidade de um número maior de observações, em termos de número de empresas e/ou quantidade de períodos, para se conseguir realizar um ajuste confiável. 
onde,

- $N I_{i t}$ é o lucro líquido no ano $t$, dividido pelo total de ativos no ano $t$,

- $\Delta N I_{i t}$ é a variação anual de $N I$ no ano $t$, dividida pelo total de ativos no ano $t$

- $S I Z E_{i, t-1}$ é o logaritmo natural do total de receitas no ano $t-1$

- $G R O W T H_{i, t}$ é a taxa de crescimento anual do total de receitas (líquidas) no ano $t$

- EISSU $E_{i, t}$ é uma variável dummy que assume valor igual a 1 se as vendas de ações ordinárias e preferenciais no ano $t$ são maiores que $10 \%$ do total de ativos do ano $t$ e zero caso contrário.

- $L E V_{H i, t}$ são os passivos totais dividido pelo valor contábil do patrimônio do fim do ano $t$.

- DISSUE $E_{i, t}$ é a taxa de crescimento anual dos passivos totais no ano $t$.

- $A T O_{i, t}$ é a receita líquida total do ano $t$ dividida pelos ativos totais do ano $t$.

- $C F O_{i, t}$ é o fluxo de caixa das atividades operacionais no ano $t$ dividido pelo total de ativos no ano $t$.

- $B I G_{i, t}$ é uma variável dummy que assume valor igual a 1 se a empresa é auditada por BIGN e 0 caso contrário.

Essa equação foi estimada por Harris (2012) em cada um dos períodos de interesse e, a variância dos resíduos, em cada situação, foi considerada como um indicador da variabilidade do resultado. Essa consideração parte do pressuposto de que tais resíduos representam a variabilidade no resultado não relacionada às demais variáveis de controle e portanto, decorrente de discricionariedade. Assim, ao final, a autora confrontou a variabilidade dos resíduos em cada um dos períodos, identificando que o período com maior qualidade da auditoria foi aquele com menor variabilidade no resultado decorrente de discricionariedade. Essa análise pode ser extrapolada para outras situações, confrontando o nível de qualidade da auditoria através da análise descrita em diferentes situações, sempre lembrando que, quanto menor a variabilidade dos resíduos, maior será a qualidade da auditoria na situação analisada.

\section{(ii) Métricas baseadas em informações de mercado}

As métricas de qualidade de auditoria baseadas em informações de mercado partem de uma linha de pesquisa que considera uma dimensão reputacional do auditor, ou seja, considera a percepção sobre a qualidade da auditoria por parte dos usuários das informações 
auditadas, o que determina o grau de confiança que atribuirão a essas informações. Assim, os determinantes da qualidade percebida de auditoria podem ser estimados através de medidas baseadas em informações de mercado, como exemplo, por meio dos preços de ativos que tenham influência potencial de informação contábil auditada (Braunbeck, 2010).

Dentro dessa linha, o tipo de pesquisa mais explorado faz uso do Earnings Response Coefficients (ERC), ou seja, coeficiente estimado através de regressão de métricas de mercado (por exemplo, preços das ações) e resultados contábeis. Desse modo, considera que, se as informações contábeis forem capazes de influenciar, por exemplo, o preço do ativo, isso indica relevância (value relevance) e confiabilidade de tal informação, podendo extrapolar e presumir relevância e confiabilidade também no relatório da auditoria, indicando, portanto, qualidade da auditoria. O uso desse tipo de métrica pode ser observados em trabalhos, como os de Ghosh e Moon (2005), de Behn, Choi, e Kang (2008) e Hussainey (2009).

\section{(iii) Métricas baseadas em informações resultantes do próprio processo de} auditoria

O processo de auditoria é composto por várias etapas, que vão desde o planejamento do trabalho, a execução de procedimentos para obtenção de evidências, até a emissão do relatório de auditoria apresentando a opinião do auditor. É possível identificar recursos alocados (inputs) nesse processo, como é o caso, por exemplo, do tempo, do conhecimento e dos honorários. Também é possível verificar o seu resultado (output) através do relatório do auditor. Nesse contexto, diversos pesquisadores se valeram desses inputs e output como proxies para a qualidade da auditoria.

Uma das proxies oriundas do processo de auditoria mais comumente vista é a opinião previamente emitida pelo auditor em seu relatório, relacionada a algum evento crítico conhecido ex post, como casos de situação explícita de insolvência. Nesse caso, a opinião previamente emitida poderá oferecer evidências sobre a qualidade de auditoria realizada ex ante (Braunbeck, 2010). Alguns exemplos de trabalho que se valeram da análise da qualidade da auditoria, observada através da opinião do relatório do auditor ex ante diante de eventos críticos ex post, são Geiger e Raghunandan (2002), Carey e Simnett (2006) e Santos (2008).

Outra variável observável em alguns países, em alguns períodos de tempo, e que frequentemente vem sendo utilizada pelos pesquisadores são os honorários de auditoria. A ideia por trás desse construto é que o auditor possuirá diferentes níveis de incentivos para ser independente e, considerando a demanda e a oferta por serviços de auditoria, oferecerá também níveis diferentes de qualidade de auditoria nesse mercado. Assim, por existir variados incentivos tanto para a oferta, quanto para a demanda, é razoável supor que o mercado de auditoria apresente diferenciação de produto em função dos valores de 
honorários praticados. Daí, surgem trabalhos que relacionam a qualidade da auditoria com os honorários e porte da empresa de auditoria, como são os casos de Francis (1984) e de Carson (2009).

Uma outra medida de qualidade encontrada na literatura é o esforço de auditoria que, conforme afirmado por Caramanis e Lennox (2008), afeta a probabilidade de que o auditor detecte um problema nas demonstrações contábeis sendo, portanto, determinante da qualidade de auditoria. Nesse sentido, embora esse tipo de informação seja de acesso restrito, alguns autores como Leventis e Caramanis (2005) e Caramanis e Lennox (2008) tiveram acesso a bancos de dados privados e conseguiram desenvolver seus trabalhos usando as horas incorridas (esforço de auditoria) pelas firmas como proxy de qualidade de auditoria.

Por fim, ainda dentro do contexto das métricas baseadas em informações resultantes do processo de auditoria, vale destaque o construto de Braunbeck (2010) para o mercado brasileiro. O referido autor criou um índice de qualidade de auditoria, observável a nível da firma, baseado em informações dos relatórios de auditoria e em outras informações subjacentes, denominado $I Q U A$. Esse índice é composto por questões binárias que buscam agregar situações que sugerem qualidade inferior da auditoria realizada (essas questões assumem valor 1 quando existem problemas de qualidade de auditoria e 0 na inexistência de tais problemas). Assim, somando os valores de cada questão, tem-se o valor do $I Q U A$, que, à medida que assume valores maiores indica uma menor qualidade de auditoria (Braunbeck, 2010). Cada questão que compõe o IQUA, e a razão de integrarem o referido índice, estão descritas a seguir.

Questão 1: As demonstrações contábeis tiveram sua republicação exigida pela CVM?

A determinação da CVM de exigir republicação das demonstrações contábeis é considerada evidência de qualidade inferior da informação originalmente arquivada pela companhia e, portanto, qualidade inferior da auditoria.

Questão 2: O auditor das demonstrações contábeis foi objeto de Processo Administrativo Sancionador?

Os órgãos reguladores, mais especificamente a CVM, no caso do Brasil, no seu papel de regulador, tem a prerrogativa de sancionar os participantes do mercado, inclusive os auditores, sempre que alguma desconformidade seja identificada. Nesses casos, instaura Processos Administrativos Sancionadores (PAS) para analisar as situações em que são detectadas eventuais irregularidades.

Assim, é natural supor que, o fato de o auditor ter sofrido e sido julgado num processo relacionado a um cliente específico, seja considerado como evidência de problemas de qualidade da auditoria do cliente em questão, no período referido. 
Questão 3: O relatório de auditoria do último ano do período em que um mesmo auditor foi responsável por emitir opinião conteve algum tipo de modificação relevante (ressalva, negativa, abstenção, ênfase ou limitação de escopo), em comparação com opinião emitida por esse mesmo auditor no ano sob análise (i.e., o auditor emitiu um parecer mais "rigoroso" no seu último ano antes de ser substituído)?

DeAngelo (1981a) apresentou evidências de que, quanto mais relevantes forem as quase rendas de clientes específicos, maior será o incentivo do auditor para não reportar falhas detectadas. A partir dessa ideia, pode-se supor que, no último ano de relacionamento auditor-auditado, o auditor apresente maior nível de independência, visto não existir horizonte futuro para ele ter novas rendas advindas desse cliente (sobretudo no Brasil, que utiliza a regra de rodízio mandatório de firmas de auditoria) e, portanto, tenha maior incentivo para reportar as falhas detectadas.

Questão 4: O relatório de auditoria do $1^{\circ}$ ou $2^{\circ}$ anos de emissão consecutiva de opinião pela empresa de auditoria sucessora teve uma abordagem menos "rigorosa" que o último parecer emitido pelo auditor sucedido?

A ideia por trás dessa questão é semelhante à da questão 3, ou seja, espera-se que o auditor apresente menor nível de independência nos primeiros anos de relacionamento com seu cliente, baseado na teoria das quase rendas de DeAngelo (1981a).

Questão 5: Caso a resposta de 3 tenha sido "não" - O primeiro relatório de auditoria emitido pelo auditor sucessor conteve algum tipo de modificação relevante (ressalva, negativa, abstenção, ênfase ou limitação de escopo), em comparação com opinião emitida pelo auditor sucedido (i.e., o auditor substituto emitiu parecer mais "rigoroso" no primeiro ano após a substituição?)?

Se, apesar dos incentivos decorrentes da quebra do contrato, o auditor sucedido ainda assim não manifestar independência, não evidenciando falhas encontradas, o auditor sucessor pode ser mais independente e, eventualmente, revelar em seu primeiro relatório de auditoria as falhas omitidas pelo seu antecessor. Nesse caso, se o auditor sucessor apresentar uma opinião mais "rigorosa" que o auditor sucedido, isso pode ser considerado um problema de qualidade da auditoria do auditor antecessor.

Questão 6: O relatório de auditoria foi emitido mais de 60 dias após a data-base das demonstrações contábeis?

Esta questão tem como base a literatura internacional acerca de Audit Delay (Ashton, Willingham, e Elliott (1987), L. E. Johnson (1987), Imam, Ahmed, e Khan (2001), Afify (2009)). Audit Delay consiste no prazo existente entre a data das demonstrações contábeis e a data da emissão do relatório de auditoria correspondente, sendo considerado pela literatura que esse prazo pode estar associado com a detecção de problemas pelo auditor e à negociação entre auditor e cliente, acerca do tratamento a ser dado a tais 
problemas. Assim, embora existam outros fatores na determinação do Audit Delay, esse prazo pode ser considerado um indicador de possíveis problemas na qualidade da auditoria. No caso do $I Q U A$, considera-se que relatórios de auditoria assinados há mais de 60 dias após a data das demonstrações contábeis são indicativos de problema com a qualidade da auditoria.

Questão 7: Caso a empresa tenha apresentado situação de insolvência, caracterizada por concordata, recuperação judicial ou falência, o auditor não emitiu relatório de auditoria com ressalva no tocante à continuidade e/ou à situação financeira no exercício anterior à divulgação da situação de insolvência?

Questão 8: Caso a empresa tenha apresentado situação de insolvência, caracterizada por concordata, recuperação judicial ou falência, o auditor não emitiu relatório de auditoria com parágrafo de ênfase no tocante à continuidade e/ou à situação financeira no exercício anterior à divulgação da situação de insolvência?

As demonstrações contábeis, tanto no Brasil como em outras partes do mundo, são elaboradas dentro do pressuposto de continuidade das companhias. Nesse sentido, sempre que encontrar qualquer evidência de que a continuidade possa ter sido comprometida, é obrigação do auditor informar em seu relatório de auditoria os fatos ou incertezas a esse respeito. As respostas das questões 7 e 8 levam em consideração o que foi mencionado pelo auditor em seu parecer em período anterior à divulgação de eventos de dificuldade financeira, legalmente declarados (antiga concordata, falência ou recuperação judicial). Dessa maneira, caso tenha ocorrido um evento dessa natureza e, no relatório do período anterior, o auditor não tenha mencionado o fato, isso é um indicativo de problema da qualidade da auditoria do ano anterior.

No Brasil, esses eventos de dificuldades financeiras podem ser identificados através do Boletim Diário de Informações da BOVESPA e do Cadastro Geral da CVM (Comissão de Valores Mobiliários (CVM), 2017).

\subsection{O período de relacionamento auditor-auditado (audit tenure) e a qualidade de auditoria}

A independência do auditor pode ser considerada a vertente da qualidade de auditoria que mais causa preocupação e, consequentemente, discussões. Uma das principais questões quando se fala em independência do auditor é o período de relacionamento auditor-auditado (audit tenure). Existem duas visões opostas sobre os efeitos da audit tenure sobre a qualidade da auditoria. Uma afirma que quanto mais longo o período de relacionamento auditor-auditado, maior é a familiaridade que o auditor desenvolve com seu cliente, tornando-se mais propenso a agir em favor desse, reduzindo então a qualidade 
da auditoria. A outra visão é de que, quanto mais longo o período de relacionamento do auditor com seu cliente, mais o auditor aumenta seu entendimento sobre o negócio e maior se torna sua expertise durante a auditoria, resultando em maior qualidade de auditoria (Tepalagul \& Lin, 2014).

Em termos dos efeitos do tempo de relacionamento auditor-auditado na independência, o rodízio de auditoria é frequentemente considerado como um meio de evitar a dependência do auditor em relação ao seu cliente e, portanto, como um meio de melhorar a qualidade da auditoria. Os defensores do rodízio mandatório de firmas de auditoria argumentam que os ciclos de rodízio levariam as firmas de auditoria a observar com mais objetividade suas regras de monitoramento, removendo a percepção da natureza de longo prazo do contrato de trabalho de auditoria. Quando o relacionamento auditor-auditado aumenta o nível de percepção dos membros da equipe de auditoria (amplamente definida) de que o relacionamento auditor-auditado está baseado em um contrato de longo prazo, com baixo risco de demissão, ocorre uma potencial ameaça à independência do auditor.

À medida que a equipe de auditoria se torna mais preocupada com os fluxos futuros de lucro, o ceticismo profissional ou os julgamentos profissionais sobre o design dos programas de auditoria ou das evidências de avaliação de auditoria podem ser prejudicados ou tendenciosos (Harris, 2012). De acordo com Hoyle (1978), na ausência de rodízio de auditoria, o auditor pode usar a mesma abordagem e o mesmo programa de auditoria por vários anos, de modo que a auditoria vai perdendo a criatividade até chegar a um ponto em que ela se torna previsível e inefetiva. O rodízio propicia uma nova perspectiva sobre as demonstrações financeiras do cliente e a nova firma de auditoria pode ser capaz de detectar erros e fatos que poderiam ter sido ignorados pela firma de auditoria anterior (McLaren, 1958). Isto também traz a oportunidade de examinar o trabalho de outras firmas, adicionalmente aos programas de revisão pelos pares (Catanach \& Walker, 1999). Dessa forma, as firmas de auditoria podem ser motivadas a oferecer o melhor serviço possível para evitar embaraços, visto que experts irão julgar seu trabalho e também em função da competição e do desejo de atrair novos clientes (Al-Khoury et al., 2015).

Esse problema é conhecido como "ameaça de familiaridade", onde o auditor tende a antecipar evidência de auditoria (baseado em seus trabalhos anteriores), ao invés de adotar um processo de obtenção de evidências rigoroso e inovativo. Colaboradores da literatura em auditoria têm reconhecido o potencial de ocorrer esse problema em longos relacionamentos auditor-auditado (Harris, 2012). O problema da familiaridade já é antigo, por exemplo, a quase meio século atrás os autores Mautz e Sharaf (1961, citado por Harris, 2012) já advertiam que:

A maior ameaça à sua independência é uma lenta erosão, gradual e quase casual desse honesto desinteressado - o auditor responsável deve constantemente relembrar seus assistentes da importância e do significado operacional da independência. (página 21) ${ }^{7}$

\footnotetext{
$\overline{7}$ The greatest threat to his independence is a slow gradual, almost casual erosion of this honest
} 
Adicionalmente, longos períodos de relacionamento auditor-auditado podem criar incentivos econômicos para que o auditor se torne menos independente. Nesse caso, o auditor pode vir a concordar com demandas dos seus clientes visando continuar assegurando seus honorários futuros (Hoyle, 1978). O auditor depende do cliente, que representa uma fonte de renda e, por esta razão, quando ele não dá uma opinião de acordo com os desejos do cliente, teme que o cliente troque de auditor (Junaidi, Apriyanto, Nurdiono, \& Suwardi, 2014).

Aninat, Bustos, e Riutort (2015) apresentam os benefícios e os custos da manutenção do auditor por um período prolongado de tempo, os quais estão apresentados a seguir.

\section{Benefícios de se manter o auditor:}

- Manter uma firma de auditoria por um longo período de tempo significa reduzir o número de vezes que novos auditores precisarão incorrer em custos iniciais (start up costs). Os benefícios de se auditar um cliente durante longo período de tempo decorre do envolvimento e conhecimento da empresa, aproveitando-se das curvas de aprendizagem, como proposto por DeAngelo (1981b). Trocando-se menos frequentemente de auditor, incorre-se menos em custos iniciais de auditoria.

- A familiaridade com a companhia permite que o auditor calcule com precisão o nível de risco da empresa, seja mais eficiente com o gerenciamento de informações e evite informações menos relevantes.

- Um curto período de relacionamento auditor-auditado, ao afetar o conhecimento do auditor específico sobre seu cliente, pode levar a uma erosão na qualidade da auditoria e ser associado com incremento no risco de litígio para a firma de auditoria. Auditores obtêm vantagem competitiva via especialização e clientes perdem os benefícios resultantes caso troquem de auditor (W. B. Johnson \& Lys, 1990).

- Um período de relacionamento mais longo com o cliente incentiva o auditor a investir mais no desenvolvimento de ativos que são altamente relacionados com o cliente em questão, o que é essencial para os seus serviços profissionais. O auditor terá maiores incentivos a investir se ele souber que seu contrato pode durar por muitos anos (Arruñada \& Paz-Ares, 1997). A literatura menciona investimentos insuficientes em termos de ativos específicos devido ao risco de expropriação após o investimento, como o problema de hold up ${ }^{8}$. Um relacionamento duradouro com o auditor poderia

disinterestedness-the auditor incharge must constantly reind his assistantants of the importance and operational meaning of independence. (p. 21)

8 O conceito de hold up descreve a situação em que uma das partes possui vantagens no momento que a outra é forçada a renegociar os termos do contrato. Assim, o problema de hold up pode ser entendido como o risco de se sujeitar a comportamentos oportunísticos ex post com a realização de investimentos específicos e ocorre quando uma das partes na relação contratual pode explorar a vulnerabilidade da contraparte devido à especificidade dos ativos envolvidos (Angelo, 2006). 
reduzir esse problema.

- Outro importante benefício é a assimetria de informações entre a empresa de auditoria e seu cliente, que é reduzida por ter uma relação duradoura entre as duas partes, reduzindo o risco e, com isso, os honorários cobradas pela empresa de auditoria, o que agrada inclusive aos investidores.

Resumindo, os argumentos acima advogam que um longo período de relacionamento auditor-auditado traz maiores benefícios que um relacionamento curto.

\section{Custos de se manter o auditor:}

- Em primeiro lugar, a perda de independência do auditor poderia aumentar a probabilidade de ocorrência de um evento que destrua valor da companhia auditada. Um exemplo disso é o caso da empresa norte americana Enron, que gerou uma enorme perda de valor não só para os acionistas da empresa, mas para o mercado financeiro como um todo.

- Os custos de um escândalo financeiro podem ser consideráveis e traduzidos em aumento no risco dos ativos pertencentes à empresa e, portanto, numa redução de seu valor econômico. Segundo, dado que a firma de auditoria tem incentivo de reter o cliente, isto poderia levá-la a ocultar informações.

- Conforme mencionado por Arruñada (1997), os auditores, a fim de reter um cliente, são capazes de reduzir seus honorários no início da relação contratual, aumentando-os posteriormente. Esta prática, conhecida como low balling ${ }^{9}$ na literatura (DeAngelo, 1981a), aumenta o incentivo do auditor em manter seu cliente, tornado o relacionamento de longo prazo, visto que os honorários sobem de valor com o tempo, enquanto os custos caem, trazendo maiores benefícios econômicos com o decorrer do tempo. Por essa razão, os auditores podem esconder informações relevantes do mercado para evitar perder o cliente.

- Outro custo do low balling é que, uma vez que o auditor adquire um cliente, existe um custo para o cliente trocar de auditor, visto que o sistema interno que a empresa utiliza para alimentar as informações para os auditores precisa ser redesenhado, gerando custos adicionais (Arruñada, 1997). Portanto, uma estratégia de preço muito baixo (inclusive abaixo do custo marginal) é rentável para o auditor porque, uma vez que transcorrem os primeiros anos de auditoria, o custo da mudança de auditor para o cliente já terá sido gerado, permitindo ao auditor cobrar então um preço acima do custo marginal e recuperar suas perdas ocorridas nos anos iniciais. Isto

$9 \quad$ Low balling consiste no ajuste de honorários de auditoria abaixo do custo corrente no início dos trabalhos de auditoria. 
é particularmente importante, pois fornece um incentivo para o auditor manter o relacionamento quando ele está em seus estágios iniciais, o que poderia afetar o seu incentivo para revelar informações ao mercado. Esse problema é reduzido através do rodízio mandatório de firmas, tendo em vista que estabelece-se um prazo limite para a duração do contrato de auditoria.

- Outro importante custo é a queda da qualidade da auditoria para níveis abaixo do ótimo decorrente da confiança que o auditor adquire por pensar que já conhece a empresa, que pode levá-lo a perder detalhes importantes na análise das demonstrações financeiras. Os defensores do rodízio mandatório chamam isso de "novo ponto de vista" ("fresh point of view"), embora os oponentes ao regime de rodízio mandatório dizem que isso não pode ser comprovado (Cameran et al., 2005).

Mas o fato é que o rodízio mandatório de firmas de auditoria é considerado um mecanismo para o fortalecimento da independência do auditor externo e, consequentemente, da qualidade da auditoria. Tal mecanismo tem tido a sua relevância destacada pelos órgãos reguladores ao redor do mundo, sobretudo após escândalos de fraudes financeiras.

De acordo com os pesquisadores Cameran et al. (2005), da SDA Bocconi, somente Brasil, Itália, Índia, Singapura e Coréia do Sul determinavam o rodízio de firmas em seus respectivos mercados até pouco tempo, sendo que alguns outros países, tais como Áustria, Canadá e Espanha, já adotaram tal regime em períodos anteriores, mas o aboliram. Mais recentemente, a Comissão Europeia aprovou o regulamento EU No 537/2014, estabelecendo o rodízio mandatório em uma das maiores regiões econômicas do mundo ${ }^{10}$. Além disso, a forma de aplicação do rodízio mandatório nos países que adotam o regime não é a mesma, variando aspectos como o número de períodos em que as firmas devem ser rodiziadas e a determinação (ou não) de tempo mínimo para manutenção da mesma firma de auditoria. Existem ainda países que não adotam o rodízio de firmas, mas adotam o rodízio de sócios de auditoria, como é o caso dos Estados Unidos.

A seguir está apresentada a situação do rodízio mandatório de auditoria ao redor do mundo.

\subsubsection{Aplicação do rodízio mandatório de auditoria no mundo}

Esta seção destina-se a apresentar uma visão geral das decisões de alguns países acerca do processo de rodízio de auditoria. Mais especificamente, as subseções 2.3.1.1 e 2.3.1.2, apresentam uma revisão feita por Cameran, Negri, e Pettinicchio (2015), que

$\overline{10}$ O regulamento EU No 537/2014 requer que empresas listadas, bancos e instituições financeiras nomeiem um novo auditor a cada 10 anos, podendo esse prazo ser estendido por mais 10 anos se a empresa oferecer seu contrato de auditoria a novas ofertas ou se contratar uma nova empresa para fazer auditoria conjunta. 
resume o tratamento dado ao rodízio de firmas de auditoria e de sócios de auditoria nos principais países onde a regra é discutida.

Será apresentado, primeiramente, a situação de países que já adotaram a regra de rodízio mandatório de firmas de auditoria e depois a aboliram. Posteriormente, será apresentado um quadro resumindo os países que adotam o rodízio mandatório de firmas de auditoria e/ou o rodízio mandatório de sócios, apresentando as principais características da adoção em cada um desses países. E, na sequência, tem-se duas subseções apresentando a situação da regra em casos relevantes, especificamente Estados Unidos e União Europeia, e uma terceira subseção discutindo o funcionamento da regra no Brasil, país foco deste trabalho.

Falando primeiramente dos países que já adotaram o regime e depois o aboliram, pode-se começar pelo Canadá. O Canadá introduziu o regime de rodízio mandatório de firmas de auditoria muito antes de outros países (logo após o colapso do Home Bank em 1923) e permaneceu com esse regime até 1991, quando houve a revisão da Lei Bancária (U.S. Government Accountability Office - GAO, 2003) e considerou-se que os benefícios do rodízio não superavam os custos iniciais do auditor sucessor. Em outros países o rodízio de firmas foi adotado e, logo em seguida, revogado, como foi o caso da Espanha. Na Espanha o rodízio de firmas a cada nove anos vigorou de 1988 a 1995, a regra foi abolida antes mesmo que o primeiro mandato das firmas de auditoria tivesse fim (Ruiz-Barbadillo, Gómez-Aguilar, \& Carrera, 2009). Singapura também introduziu o rodízio mandatório para bancos em 2002 e depois o "suspendeu temporariamente" em 2008, sob a justificativa de que os reguladores não desejavam introduzir mais encargos sobre os bancos durante a última crise financeira. Por fim, o caso de Costa Rica é emblemático: o rodízio de firmas de auditoria foi introduzido em 2005, aplicado em 2006, extinto em 2007 e reimplementado em 2010 (Cameran, Negri, \& Pettinicchio, 2015).

A Tabela 2, apresentada a seguir, foi obtida de Cameran, Negri, e Pettinicchio (2015) e fornece uma visão geral do status do rodízio de auditoria em alguns países, atualizada até fevereiro de 2015. O rodízio mandatório é estabelecido, predominantemente, para entidades de interesse público, mas os autores não fizeram a identificação exata do tipo de entidades legais que são obrigadas a rodiziar o sócio ou a empresa de auditoria. Os autores consideraram os países membros da União Europeia, os países que são similares à União Europeia devido a suas condições econômicas e os países que não pertencem à União Europeia, mas que assumiram uma posição peculiar em relação ao rodízio mandatório, para os quais os autores conseguiram informações. Os casos dos Estados Unidos, da União Europeia e do Brasil, estão apresentados separadamente, de forma mais detalhada, nas subseções seguintes. 
Tabela 2 - O rodízio de auditoria no mundo.

\begin{tabular}{|c|c|c|c|}
\hline País & Rodízio de sócio & $\begin{array}{l}\text { Rodízio de firma de au- } \\
\text { ditoria }\end{array}$ & Fonte \\
\hline Austrália & 5 anos & Não & http://www.cpaaustralia.com.au \\
\hline Áustria & 5 anos & $\begin{array}{l}5 \text { anos para empresas gover- } \\
\text { namentais }\end{array}$ & $\begin{array}{l}\text { EY Transparency Report } 2014 \text { and http:// } \\
\text { wWw. crowehorwath.net }\end{array}$ \\
\hline Bélgica & 6 anos & $\begin{array}{l}\text { Não (recontratação a cada } \\
3 \text { anos, sem limites) }\end{array}$ & Ewelt-Knauer, Gold, e Pott (2012) \\
\hline Brasil & $\begin{array}{l}\text { Não (empresas listadas) } \\
5 \text { anos (instituições fi- } \\
\text { nanceiras) }\end{array}$ & $\begin{array}{l}5 \text { anos (companhias listas - } \\
\text { sendo } 10 \text { anos caso a com- } \\
\text { panhia possua comitê de } \\
\text { auditoria estatutário) } \\
\text { Não (instituições financei- } \\
\text { ras) }\end{array}$ & $\begin{array}{l}\text { vide Harris e Whisenant (2012) e a seção a } \\
\text { seguir. }\end{array}$ \\
\hline Bulgária & 5 anos & Não & http://www.crowehorwath.net \\
\hline Canadá & 7 anos & Não & http://www.cga-canada.org \\
\hline China & 5 anos & $\begin{array}{l}5 \text { anos para instituições fi- } \\
\text { nanceiras e empresas gover- } \\
\text { namentais (deve haver um } \\
\text { concurso a cada } 3 \text { anos) }\end{array}$ & $\begin{array}{l}\text { Lennox, Wu, e Zhang (2014) e http:// } \\
\text { economia.icaew.com }\end{array}$ \\
\hline Croácia & 7 anos & $\begin{array}{l}7 \text { anos para bancos e } 4 \text { anos } \\
\text { empresas de seguro e lea- } \\
\text { sing }\end{array}$ & $\begin{array}{l}\text { http://anale.feaa.uaic.ro/ e Ewelt- } \\
\text { Knauer et al. (2012) }\end{array}$ \\
\hline Chipre & 7 anos & Não & EY Transparency Report 2013 \\
\hline República Checa & 7 anos & Não & Ewelt-Knauer et al. (2012) \\
\hline Dinamarca & 7 anos & Não & EY Transparency Report 2014 \\
\hline Estônia & & & 7 anos \\
\hline Finlândia & 7 anos & Não & Ewelt-Knauer et al. (2012) \\
\hline França & 6 anos & $\begin{array}{l}\text { Não ( } 6 \text { anos com auditoria } \\
\text { conjunta, mas pode ser re- } \\
\text { novado) }\end{array}$ & $\begin{array}{l}\text { André, Broye, Pong, e Schatt (2016) e Fran- } \\
\text { cis, Richard, e Vanstraelen (2009) }\end{array}$ \\
\hline Alemanha & 7 anos & Não & Ewelt-Knauer et al. (2012) \\
\hline Grécia & 7 anos & Não & EY Transparency Report 2013 \\
\hline Hungria & 7 anos & Não & $\begin{array}{l}\text { Informação obtida diretamente através de } \\
\text { relacionamento com a EY }\end{array}$ \\
\hline Irlanda & 5 anos & Não & http://www.cpaireland.ie \\
\hline Itália & 7 anos & 9 anos & Cameran, Francis, Marra, e Angela (2015) \\
\hline Letônia & 7 anos & Não & EY Transparency Report 2014 \\
\hline Lituânia & $\begin{array}{l}5 \text { anos para EIPs; } 7 \text { anos } \\
\text { para algumas entidades } \\
\text { de outros regimes legais }\end{array}$ & Não & http://www3.lrs.it/ \\
\hline Luxemburgo & 7 anos & Não & Ewelt-Knauer et al. (2012) \\
\hline Malta & 7 anos & Não & EY Transparency Report 2013 \\
\hline Polônia & 5 anos & Não & $\begin{array}{l}\text { Informação obtida diretamente através de } \\
\text { relacionamento com a EY }\end{array}$ \\
\hline Portugal & 7 anos & $\begin{array}{l}\text { Não (8-9 anos para compa- } \\
\text { nhias listadas em uma re- } \\
\text { gra de "cumprir ou expli- } \\
\text { car" }\end{array}$ & Ewelt-Knauer et al. (2012) \\
\hline Roménia & 7 anos & Não & http://www.crowehorwath.net \\
\hline Singapura & $\begin{array}{l}5 \text { anos para companhias } \\
\text { listadas; } 7 \text { anos para ou- } \\
\text { tras EIPs }\end{array}$ & Não & $\begin{array}{l}\text { Informação obtida diretamente através de } \\
\text { relacionamento com a EY }\end{array}$ \\
\hline Eslováquia & 5 anos & 5 anos & http://www.crowehorwath.net \\
\hline Eslovênia & 7 anos & $\begin{array}{l}5 \text { anos para bancos e indús- } \\
\text { trias de seguros }\end{array}$ & Ewelt-Knauer et al. (2012) \\
\hline Corea do Sul & Não & Não & Kwon, Lim, e Simnett (2014) \\
\hline Espanha & 7 anos & Não & Ruiz-Barbadillo et al. (2009) \\
\hline Suécia & 7 anos & Não & http://lup.lub.lu.se/search/ \\
\hline Holanda & 7 anos & Não & http://ey.com/Publications \\
\hline Turquia & 5 anos & 7 anos & $\begin{array}{l}\text { Informação obtida diretamente através de } \\
\text { relacionamento com a EY }\end{array}$ \\
\hline Reino Unido & 5 anos & $\begin{array}{l}10 \text { anos a partir de } 01 \text { de } \\
\text { janeiro de } 2015\end{array}$ & https://www.gov.uk/ \\
\hline Estados Unidos & 5 anos & Não & veja na seção a seguir \\
\hline
\end{tabular}

Obtido em Cameran, Negri, e Pettinicchio (2015).

Dados atualizados até fevereiro de 2015 


\subsubsection{O rodízio de auditoria nos Estados Unidos}

Os Estados Unidos apresentam sempre uma posição diferente dos demais países quando o assunto é o rodízio mandatório de firmas de auditoria. Os Estados Unidos tem uma longa experiência com rodízio de sócios de auditoria, que foi introduzido em 1978, com um prazo de 7 anos para a troca de sócio (American Institute of Certified Public Accountants (AICPA), 1978), no entanto, o debate sobre o rodízio de firmas esteve na agenda da Câmara dos Deputados até 2014 (Cameran, Negri, \& Pettinicchio, 2015).

O interesse a respeito do rodízio de sócios e de firmas de auditoria tipicamente tem sido influenciado por episódios de fraudes e falências. Após os principais casos de fraudes ocorridos no início dos anos 2000, o Artigo 203 da Lei Sarbanes-Oxley de 2002 declarou que passou a ser ilegal que uma empresa de contabilidade pública registrada forneça serviços de auditoria a um cliente se o sócio de auditoria líder (ou coordenador), ou o sócio de auditoria responsável pela revisão da auditoria, tiver realizado serviços de auditoria para esse cliente em cada um dos cinco exercícios fiscais anteriores. Essa política enfatizou o rodízio obrigatório de cinco anos para sócios de auditoria, reduzindo a regra anterior em dois anos. Ao mesmo tempo, a Seção 207 da Lei exigiu que a GAO realizasse um estudo sobre o rodízio mandatório de firmas de auditoria. Nos termos da Seção 20, a Comissão de Valores Mobiliários dos Estados Unidos (SEC), também solicitou um estudo sobre as possíveis implicações desse tipo de rodízio. Após um ano de realização de pesquisas entre as empresas de contabilidade e as empresas de capital aberto publicadas na Fortune 1.000, no estudo requerido sobre os efeitos potenciais do rodízio mandatório de firmas de auditoria (U.S. Government Accountability Office - GAO, 2003), o GAO afirmou acreditar que o rodízio mandatório de firmas de auditoria pode não ser a maneira mais eficiente de fortalecer a independência do auditor e melhorar a qualidade da auditoria, considerando os custos financeiros adicionais e a perda de conhecimento institucional do auditor anterior sobre as companhias de interesse público (Cameran, Negri, \& Pettinicchio, 2015).

Após esse episódio, o assunto ficou fora de pauta por outra década, até que, em 2011, o PCAOB voltou a sugerir que o rodízio de firmas teria sido a melhor maneira de conferir uma alto nível de ceticismo profissional nas auditorias (Cameran, Negri, \& Pettinicchio, 2015). Neste mesmo ano, o PCAOB emitiu um concept release sobre "independência na auditoria e rodízio mandatório de firmas" (PCAOB, 2011), no qual o órgão solicitou comentários públicos sobre as vantagens e desvantagens do rodízio mandatório de firmas, considerando novamente a sua implementação, ainda que apenas por um período de teste. Nesse mesmo documento, o PCAOB, diante da escassez existente na literatura, solicitou ainda estudos a respeito de um prazo para rodízio de firmas, caso a regra viesse a ser implementada no futuro.

Dois anos depois, em julho de 2013, o Congresso Americano decidiu contra o rodízio mandatório de firmas de auditoria. Por fim, depois de três anos de trabalho, em fevereiro 
de 2014, o presidente do PCAOB, James Doty, informou à SEC que, embora não tenham um projeto ativo ou um trabalho em curso no Board para avançar com a discussão sobre um limite de prazo para o relacionamento auditor-auditado, o PCAOB continua a pensar a respeito do que afeta a independência (Doty, 2014), deixando de lado o rodízio mandatório de firmas. Na mesma reunião aberta da SEC, do orçamento do PCAOB de 2015, o próprio James Doty voltou a enfatizar que a independência dos auditores é o valor central que o investidor espera e merece nas auditorias, no entanto não fez referência específica ao rodízio mandatório de firmas.

O que se observa é que, embora o rodízio mandatório de firmas de auditoria nunca tenha sido implementado nos Estados Unidos, recorrentemente o assunto volta à sua pauta de discussões.

\subsubsection{O rodízio de auditoria na União Europeia}

Cameran, Negri, e Pettinicchio (2015) consideram a União Europeia como uma área única. Durante a última década, a Comissão Europeia emitiu diversas orientações que dizem respeito a todos os estados-membros. Dentre elas está a diretriz 2006/43/EC, que estabeleceu o rodízio obrigatório do principal sócio de auditoria a cada sete anos para entidades de interesse público, tendo o sócio principal que respeitar um intervalo de, pelo menos, dois anos, para voltar a participar da auditoria da mesma entidade.

Os estados-membros tiveram dois anos para implementar a diretriz (até meados de 2008) e, caso achassem necessário, foram autorizados a impor requisitos mais rigorosos. Após a recente crise financeira, a European Commission emitiu, em outubro de 2010, um Green Paper intitulado: Audit policy: lessons from the crisis, (European Commission, 2010). Em particular, afirmou que, embora tenha sido dedicada muita atenção ao papel que os bancos, os hedge funds, as agências de rating, os supervisores e os bancos centrais desempenharam no período anterior à crise, nenhuma atenção foi dirigida ao papel que os auditores das empresas públicas podem ter exercido. Um dos pontos-chave levantados no Green Paper foi que, hoje em dia, um número maior de empresas está sob a responsabilidade da auditoria de um número ainda menor de Big $N$ após o desaparecimento de Arthur Andersen e a incorporação da Price Waterhouse e Coopers \& Lybrand.

Após vasta discussão sobre o assunto, com a diretriz 2014/56/EU e o Regulamento $537 / 2014$, foi introduzido um novo cenário legal para a auditoria. O objetivo desta reforma foi o aprimoramento da qualidade dos relatórios de auditoria. O mandato da empresa de auditoria para empresas de interesse público passou a ser limitado a dez anos, podendo a mesma empresa de auditoria ser reconduzida por mais quatorze anos em caso de auditorias conjuntas (quando a empresa está sendo auditada por mais de uma empresa de auditoria) ou por mais dez anos se a empresa oferecer seu contrato de auditoria a novas ofertas. Após a expiração do prazo máximo, a entidade de interesse público pode voltar a nomear a 
empresa de auditoria por mais dois anos, levando a uma regra "10 $+14+2$ ", no caso de uma auditoria conjunta durante o segundo período ou a "10 $+10+2$ ", no caso de uma única empresa fornecer o serviço de auditoria. O rodízio de sócio permaneceu obrigatório após o sétimo ano de engagement ${ }^{11}$. Ficou estabelecido que o período de rodízio da empresa e do sócio pode ser encurtado pelos estados-membros, se esses o desejarem. Esses requisitos específicos passaram a ser aplicados automaticamente a partir de junho de 2016 .

Entre 17 de junho de 2014 e 17 de junho de 2016, aos estados-membros foi dada a opção de adotar a regra de rodízio obrigatório de firma de auditoria antecipadamente e até encurtar o prazo de rodízio. Alguns países exerceram essa opção e implementaram a regra de rodízio de firmas de auditoria antes de junho de 2016. Por exemplo, no Reino Unido, a regra de rodízio de firmas foi introduzido em $1^{\circ}$ de janeiro de 2015 e nos Países Baixos entrou em vigor a partir de $1^{\circ}$ de janeiro de 2016.

\subsubsection{O rodízio de auditoria no Brasil}

No Brasil, a discussão sobre o rodízio mandatório de firmas, à semelhança de outros países, também surgiu em decorrência de escândalos financeiros, mais especificamente, escândalos envolvendo instituições financeiras na década de 1990 (Banco Econômico e Banco Nacional), que causaram grandes perdas ao mercado financeiro e a muitos detentores de contas (Oliveira \& Santos, 2007). Cada um desses bancos tinha relações de longa data com sua empresa de auditoria e, em ambos os casos, os auditores não encontraram nada de errado com as contas dos bancos, apesar das enormes irregularidades que levaram à sua liquidação. Em vez de serem altamente rentáveis, conforme descrito em suas demonstrações financeiras ao longo dos anos, ambos estiveram mascarando os livros para esconder grandes perdas em empréstimos ruins, em muitos casos dados a partes relacionadas (Martinez \& Reis, 2010).

Nesse contexto, em 1996 o Conselho Monetário Nacional do Brasil emitiu a Resolução $n^{\circ} 2267$, estabelecendo a obrigatoriedade de rodízio de firma de auditoria a cada quatro anos para instituições financeiras, com um intervalo de três anos para recontratação. Esta ação foi tomada com vistas a acalmar os mercados, mostrando firme determinação na supervisão do sistema financeiro (Martinez \& Reis, 2010). Posteriormente, em 2003, o Conselho Monetário Nacional emitiu a resolução $n^{\circ}$. 3069, estendendo o prazo do rodízio para cinco anos. Até que em 2004, foi emitida a Resolução $n^{\circ}$. 3198, que extinguiu a obrigatoriedade de rodízio de firmas e determinou que as instituições financeiras deveriam proceder à substituição do responsável técnico, diretor, gerente, supervisor e qualquer outro integrante, com função de gerência, da equipe envolvida nos trabalhos de auditoria, após emitidos pareceres relativos a, no máximo, cinco exercícios sociais completos, com um

11 Considera-se como Engagement, para fins desse trabalho, o relacionamento contratual do auditor com seu cliente. 
intervalo mínimo de três anos para recondução. Em síntese, para instituições financeiras brasileiras, atualmente, é exigido apensas o rodízio de sócio de auditoria a cada cinco anos, com intervalo de três anos para recondução.

Seguindo a liderança do Banco Central, em 1999, a Comissão de Valores Mobiliários (CVM) emitiu a Instrução CVM nº. 308/1999, estabelecendo que todas as empresas listadas em bolsa de valores deveriam contratar uma nova empresa de auditoria ou auditor individual de cinco em cinco anos, com um intervalo mínimo de três anos para recontratação (Martinez \& Reis, 2010). A CVM baseou essa decisão em sua crença de que "a prestação de serviços de auditoria à mesma empresa pública por um longo período pode prejudicar a qualidade desse serviço" (Assunção \& Carrasco, 2008).

Na ocasião da convergência brasileira para as normas internacionais de contabilidade, marcada pelo promulgação da Lei $n^{0}$ 11.638/2007, a CVM entendeu que esse momento poderia representar instabilidade indesejada, tanto para as entidades auditadas quanto para os auditores independentes (Comissão de Valores Mobiliários, 2008) e suspendeu temporariamente a regra. Considerando que em 2009 se encerraria mais um ciclo de rodízio de auditores para a maioria das companhias abertas, a CVM promulgou as Deliberações $\mathrm{n}^{\mathrm{o}}$. 549/2008 e $\mathrm{n}^{\circ}$. 669/2011, facultando a não substituição dos auditores até a data de emissão do relatório de auditoria independente para as demonstrações contábeis relativas ao exercício de 2011, para as companhias que encerram seu exercício social em data coincidente com o ano calendário, e 2012 para as demais.

Mais recentemente, em 2011, a CVM estendeu o prazo para o rodízio obrigatório de firmas em algumas situações. A Instrução CVM no 509/11 acrescentou o artigo 31A à Instrução CVM no 308/99, permitindo que o rodízio de firmas seja realizado a cada dez anos, caso a companhia auditada possua Comitê de Auditoria Estatutário em funcionamento permanente e o auditor seja pessoa jurídica, sendo que nesse caso, o auditor independente deve proceder à rotação do responsável técnico, diretor, gerente e de qualquer outro integrante da equipe de auditoria com função de gerência, em período não superior a cinco anos consecutivos, com intervalo mínimo de três anos para seu retorno (Comissão de Valores Mobiliários, 1999, 2011).

Resumindo, para as empresas listadas em bolsa, atualmente, vigora a regra de rodízio mandatório de firmas de auditoria a cada cinco anos (ou dez, caso a companhia possua Comitê de Auditoria Estatutário), com intervalo de três anos para recontratação da empresa de auditoria.

É importante salientar que o prazo de cinco anos, assim como ocorreu em outros países que adotaram a regra, foi determinado com base em "impressões" dos legisladores, haja vista que não existem evidências suficientes disponíveis para sustentar que esse é o período de tempo ideal para que as firmas de auditorias sejam trocadas. 


\subsubsection{Estudos a respeito do rodízio mandatório de firmas de auditoria}

Como se pode perceber, o rodízio mandatório de firmas de auditoria é um assunto bastante controverso e, devido ao grande interesse a esse respeito ao redor do mundo, diversos trabalhos acadêmicos já foram realizados com o intuito de verificar se esse mecanismo é realmente eficaz para a melhoria da independência da auditoria, e se os custos atrelados ao mesmo não suplantam os benefícios de sua aplicação.

Os pesquisadores Cameran et al. (2005), em um trabalho de revisão de literatura sobre o assunto, classificaram as pesquisas existentes em cinco grupos, de acordo com a relação do rodízio mandatório com (i) a independência do auditor, (ii) a qualidade de auditoria, (iii) os custos de auditoria, (iv) a competição do mercado de auditoria, e (v) a reação do mercado de capitais. No presente trabalho, foi usada a classificação dos referidos autores, com a adição de um novo grupo, (vi) prazo para o rodízio mandatório de auditoria. Possivelmente Cameran et al. (2005) não incluíram esse último grupo por inexistirem trabalhos que se enquadravam nessa categoria à época que realizaram a pesquisa. A seguir, estão apresentados alguns dos trabalhos que podem ser classificados em cada um desses grupos. Uma tabela que sintetiza estes e outros trabalhos relevantes da literatura sobre o assunto está apresentada no apêndice A.

\section{(i) Rodízio mandatório de firmas e independência da auditoria}

A independência de auditoria é uma importante questão na avaliação da confiança que se há de depositar no parecer do auditor. De acordo com Cameran et al. (2005), essa característica tem várias implicações, inclusive de naturezas políticas e profissionais. A independência melhora a credibilidade dos demonstrativos financeiros e assim adiciona valor para várias categorias de stakeholders. Além disso, a independência é a melhor maneira de evidenciar para os reguladores e para o público que os auditores estão desempenhando suas funções de acordo com os princípios éticos, tais como objetividade e integridade. Assim, devido à importância do assunto, diversos trabalhos já foram desenvolvidos sobre essa temática, estando alguns deles apresentados a seguir.

A utilização de jogos para verificar o comportamento de auditores, considerando aspectos tais como preocupação com recontratação, honorários, reputação, porte de clientes, entre outros, foi o método utilizado por diversos autores para estudar a relação entre o rodízio mandatório e a independência, como Summer (1998) que concluiu contra o rodízio, Dopuch, King, e Schwartz (2001) que concluíram a favor do rodízio e Wu-Chun, Hung-Chao, e Shih-Tsung (2002), cuja conclusão é a favor do rodízio apenas se for considerado que a reputação da firma tem efeitos sobre os honorários dos futuros clientes.

A relação entre o rodízio e a independência também foi estudada através de experimentos. Gietzman e Sen (2002) investigaram o comportamento do auditor em 
situação de clientes com ativos de risco e se posicionaram a favor do rodízio apenas em mercados menos desenvolvidos (com poucas grandes empresas). Bauer (2015) estudou a relação de identidade do auditor com o cliente e mostrou que auditores com uma identidade-cliente mais forte concordam mais com as preferências dos clientes, mas esse efeito é eliminado quando a consciência dessa identidade é destacada, de modo que o autor é contra o rodízio mandatório de firmas de auditoria.

Pesquisadores também realizaram estudos que consideraram o impacto da tenure na independência do auditor, através do estudo da percepção de gestores, auditores e outros agentes de mercado, utilizando como meio, a aplicação de questionários. Através de questionários aplicados a grandes companhias e a sócios de auditoria, O’Leary (1996) buscou analisar o conceito de independência e as consequências relativas ao rodízio mandatório na Austrália. Foram analisados 3 aspectos: a independência de fato, a independência percebida e o rodízio obrigatório. As conclusões apresentaram argumentos contra e a favor ao rodízio. Quando considerou a independência de fato, o autor encontrou evidências contra, mas quando considerou a independência percebida, as evidências foram a favor do rodízio mandatório de firmas. De forma semelhante, um estudo da SDA Bocconi School of Management (2002) também analisou a independência de auditoria de fato e percebida, através de medidas tais como suspensão de sócios, opiniões com ressalva e mudanças de auditor e também através de questionários, encontrando, assim como O'Leary (1996), argumentos a favor do rodízio quando foi considerada a independência percebida e argumentos contra quando foi considerada a independência de fato.

No Brasil, Oliveira (2005), com o objetivo de verificar se o rodízio de firmas de auditoria tem a capacidade de diminuir os riscos de perda de independência dos auditores, aplicou questionários a profissionais do mercado financeiro com vistas à identificar a percepção destes sobre o assunto. O autor chegou à conclusão de que o rodízio de firmas de auditoria não tem capacidade de assegurar a independência do auditor no seu trabalho. Formigoni, Antunes, Leite, e Paulo (2008) também verificaram a percepção de gestores de grandes companhias abertas brasileiras acerca da contribuição do rodízio de auditoria para a independência e a qualidade dos serviços prestados pelas auditorias externas, através da aplicação de questionários. Os resultados indicaram que a implementação do rodízio de firmas de auditoria, segundo a percepção dos gestores da amostra estudada, não tem contribuído nem para a independência, nem para a qualidade dos serviços prestados pelas firmas de auditoria, sendo que apenas o rodízio de auditores de uma mesma firma é considerado suficiente para manter a independência do auditor.

Alguns autores tentaram explicar a relação entre a tenure de auditoria e a independência através do desenvolvimento de modelos teóricos, como são os casos de Bamber e Iyer (2007) e Lu e Sivaramakrishnan (2009). Bamber e Iyer (2007) desenvolveram um modelo teórico para descrever o relacionamento do auditor com seus clientes, ou seja, um modelo 
de mensuração da extensão com que os auditores se identificam com seus clientes e como essa identificação pode afetar a objetividade dos auditores. O modelo foi testado através da aplicação de questionários a auditores, levando os autores à conclusão de que os auditores criam uma identificação com seus clientes e que este é um motivo para preocupação, porque os auditores que se identificam mais com um cliente são mais propensos a concordar com a posição preferida pelo cliente, em prejuízo de sua independência. Já Lu e Sivaramakrishnan (2009) estudaram os efeitos do rodízio mandatório de firmas de auditoria em decisões de investimento de companhias e na escolha do auditor num cenário de mercado de capitais. Para capturar a independência do auditor, esses autores modelaram os vieses do auditor (viés conservador ou viés agressivo) e os incentivos do cliente de auditoria em engajar o auditor com os vieses desejados (opinion shopping). Os autores concluíram que quando uma firma se engaja em "opinion shopping", o rodízio mandatório de firmas auditoria melhora a eficiência para algumas empresas, mas prejudica em outras, ou seja, o rodízio mandatório de firmas tem um efeito positivo em alguns casos, mas negativo em outros.

Uma outra maneira que vem sendo frequentemente utilizada para investigar os impactos do período de relacionamento auditor-auditado e, consequentemente, do rodízio mandatório de firmas na independência de auditoria, é a utilização de informações do relatório do auditor como proxy de independência. Através da análise da relação entre o parecer de auditoria modificado e o prazo de relacionamento do auditor com o cliente para companhias espanholas listadas, Ruiz-Barbadillo e Gomez-Aguilar (2002), concluíram que o auditor se mostra menos independente nos anos iniciais dos contratos porque ele quer recuperar o investimento inicial feito para entender o negócio do cliente. Também para empresas espanholas, Garcia-Blandon e Argiles (2015), através de regressão entre o tipo de opinião emitida pelo auditor, contra o período de relacionamento do auditor com seu cliente e outras variáveis de controle, concluíram que os auditores parecem dispostos a sacrificar sua independência em longos períodos de relacionamento, mas apenas em casos de opinião modificada decorrente de problemas de continuidade. O trabalho conclui então a favor do rodízio mandatório, mas com ressalvas em relação ao custo do regime.

\section{(ii) rodízio mandatório de firmas e qualidade da auditoria}

De acordo com DeAngelo (1981b), a qualidade da auditoria consiste na probabilidade de o auditor, simultaneamente, descobrir (competência) e reportar (independência) erros materiais. Tal probabilidade depende do conceito amplo de conduta profissional do auditor, que inclui fatores como a objetividade, o zelo profissional e o conflito de interesses. Considerando que o rodízio mandatório de firmas de auditoria pode exercer impactos nesses fatores, a relevância do tema amplia suas proporções, sendo a relação com a qualidade o tema que concentra a maior parte das pesquisas a respeito dessa regra de rodízio. Partindo da revisão de literatura de Cameran et al. (2005), alguns estudos sobre o 
assunto estão apresentados a seguir.

Através da análise de processos judiciais nos Estados Unidos, Pierre e Anderson (1984), observando o período de relacionamento entre o auditor e o cliente em cada caso, encontraram evidências contrárias ao rodízio de auditoria. Os resultados desse trabalho sugerem que erros de auditorias e processos judiciais contra auditores ocorrem mais frequentemente durante os anos iniciais do contrato de auditoria. Nessa mesma linha, Carcello e Nagy (2004) estudaram o assunto a partir de uma regressão logística usando como variável dependente o fato de demonstrações financeiras de empresas americanas terem sido (ou não) fraudadas, e como variável explicativa o período de relacionamento auditor-auditado. Os resultados encontrados por esses autores também sugerem que a probabilidade de se ter demonstrações financeiras fraudadas é maior durante os primeiros anos de relacionamento do auditor com o cliente, do que nos últimos anos. Com isso, sugerem que o rodízio mandatório pode ter efeitos negativos sobre a qualidade de auditoria. Por outro lado,Walker, Lewis, e Casterella (2001) estudaram o relacionamento de empresas que se envolveram em eventos críticos (tais como envolvimento em litígios, declaração de falência, punição pela SEC) com o tempo de relacionamento auditor-auditado, para companhias americanas no período de 1980 a 1991. Esses autores dividiram os dados por duração de tenure e observaram que a maioria dos eventos críticos ocorreram em períodos de relacionamento mais longos, mas que se a amostra for dividida por faixas de períodos de relacionamento, a taxa obtida pelo número de empresas que falharam em relação às que não falharam é maior em relacionamentos mais curtos. Por essa razão, os autores acreditam que o rodízio mandatório pode ser desnecessário, apesar de não se posicionarem contra o regime.

A associação entre a qualidade da auditoria e o longo período de relacionamento de sócio de auditoria na Austrália foi tema do trabalho de Carey e Simnett (2006). Utilizando como medidas de qualidade de auditoria: (i) a propensão do auditor a emitir uma opinião de continuidade para empresas em dificuldades; (ii) a direção e a quantidade de acréscimos anormais de accruals de capital de giro; e (iii) alcance (não alcance) de metas de lucro. Por um lado, esse estudo fornece evidências de que longos períodos de relacionamento de sócios de auditoria têm menor probabilidade de gerar opinião de continuidade e alguma evidência de alcance (não alcance) de metas de lucros, consistente com uma deterioração na qualidade da auditoria associada ao longo período de relacionamento com o sócio de auditoria. Por outro lado, nenhuma evidência de associação entre longos contratos de auditoria com acréscimos anormais de accruals de capital de giro foi encontrada, levando os autores a se oporem ao regime de rodízio mandatório. Eles alegam que os custos potenciais desse regime ultrapassam os benefícios dele decorrente, devido à perda de conhecimento específico sobre o cliente.

Estudando dados relativos à China e usando a propensão a receber um parecer de 
auditoria modificado como uma proxy para a qualidade da auditoria, Firth, Rui, e Wu (2012) encontraram que o rodízio mandatório de sócios de auditoria provoca um aumento significativo desta variável, no entanto, tal observação limita-se apenas a clientes em regiões com instituições legais fracas. Evidências similares são reportadas para o rodízio voluntário de firmas de auditoria, porém, com um nível de confiança muito menor. Quanto a outras formas de rodízio (i.e., rodízio mandatório de firma de auditoria e rodízio voluntário de sócio de auditoria), não foram encontrados efeitos na propensão a receber um parecer de auditoria modificado. Por fim, não são apresentadas evidências a favor de um rodízio mandatório de firmas de auditoria. Já Wu Xi e Zhang (2013) testaram o impacto do rodízio mandatório de sócios de auditoria na qualidade usando dados de ajustes de auditoria disponibilizadas pelo ministério das finanças da China no período de 2002 a 2006. Os resultados sugerem que o rodízio tem um impacto positivo na qualidade, uma vez que foi verificado um aumento na frequência de ajustes de auditoria no ano que antecede o rodízio mandatório e no ano subsequente. Também foram encontradas evidências, apesar de fracas, de que o rodízio mandatório traz o benefício de um olhar renovado (fresh looking) sobre a auditoria. Um ponto destacado pelos autores é que o rodízio mandatório corresponde a apenas $9,7 \%$ da amostra analisada, indicando que o rodízio voluntário é muito frequente, o que já tinha sido observado anteriormente para Austrália, Alemanha e Estados Unidos (Bedard \& Johnstone, 2010; Carey \& Simnett, 2006; Gold, Lindscheid, Pott, \& Watrin, 2012).

Diversos autores analisaram o relacionamento entre a qualidade da auditoria e o rodízio mandatório de firmas a partir de regressões de accruals discricionários contra o período de relacionamento auditor-auditado. Os accruals discricionários foram utilizados como proxies de má qualidade de demonstrações financeiras e, consequentemente, de auditoria. Entre os autores que estudaram o assunto estão Azevedo (2007); Chung (2004); Nagy (2005), que encontraram evidências a favor do regime e Azevedo e Costa (2012); Cunha, Morás, e Leite (2015); Jackson, Moldrich, e Roebuck (2008); V. Johnson, Khurana, e Reynolds (2002); Martinez e Reis (2010); Myers et al. (2003); Silva e Bezerra (2010); Silvestre (2016), que encontraram evidências contrárias.

Através de um experimento, Bates, Ingram, e Reckers (1982) verificaram se o período de relacionamento do auditor com um cliente afeta o julgamento de auditoria. No trabalho, os autores expuseram os participantes do experimento a situações com rodízio de firmas, com rodízio de sócios e sem rodízio e solicitaram julgamento quantitativo do valor da materialidade sobre divulgação de contingência judicial. Os resultados do experimento levaram os autores a concluírem que tanto o rodízio de firmas, quanto o rodízio de sócios são melhores do que a situação sem rodízio e se colocaram contra o rodízio de firmas argumentando que o rodízio de sócios pode exercer a mesma função incorrendo em menores custos. 
Utilizando modelos teóricos para a troca de auditores e para falência aplicados a companhias do Reino Unido, no período de 1987 a 1994, Lennox (1998) investigou se a troca de auditores pode ajudar a explicar porque auditores falham ao não alertar sobre falências iminentes. As evidências encontradas indicaram que empresas que praticam opinion shopping tendem a mudar os auditores que não fornecem relatórios "limpos" de auditoria, o que apoia a ideia de que, mudar obrigatoriamente os auditores, reduz de forma exógena a precisão do relatório de auditoria, que é um indicador verídico de dificuldade financeira somente se ele for emitido por auditores que estão a mais tempo com o cliente, em vez de novos auditores, bem menos informados. Esses autores entendem que a troca espontânea de firma de auditoria é um sinalizador para o mercado, de modo que o rodízio mandatório, por abolir tal sinalizador, pode nãos ser favorável. Já Elitzur e Falk (1996) desenvolveram um modelo analítico que evidencia que, quando o auditor conhece o fim de seu mandato, a qualidade do planejamento diminui ao longo do tempo e é ainda pior no último período. O modelo leva em consideração aspectos como a eficiência do auditor, os honorários de auditoria e as perdas esperadas devido a falhas. A partir dessa metodologia os autores encontraram evidências contrárias ao rodízio mandatório de firmas. Ainda nesta linha, Church e Zhang (2006) desenvolveram um modelo teórico para comparar os méritos de um sistema que requer rodízio de auditor com um sistema que não requer. Os autores demonstraram que a independência é melhorada com o sistema de rodízio mandatório, mas que o benefício líquido depende do período de rotação, dos custos iniciais, dos custos associados aos vieses de opinião, do conhecimento do auditor e do intervalo de tempo de incentivos dos gestores. O rodízio mandatório de firmas será preferível se o período de rodízio for longo, se os custos iniciais forem altos, se os custos de opiniões viesadas forem altos, se o conhecimento do auditor for dramático em termos de melhorar a eficiência da auditoria ao longo do tempo e se o gerente (auditado) for míope (for focado em benefícios de curto prazo).

Através de um estudo empírico, Harris (2012) investigou se as regras de rodízio obrigatório de auditoria estão associadas a mudanças na qualidade da auditoria, usando dados disponíveis de três países que adotaram a regra, dentre os quais, o Brasil. A autora estudou os dados antes e após a implantação da regra, avaliando seu impacto na qualidade da auditoria, usando como proxies diferentes métricas de gerenciamento de resultado. Os resultados apontaram uma melhoria na independência após a utilização do rodízio mandatório de firmas, porém revelando a necessidade de se considerar maneiras de mitigar a erosão da qualidade da auditoria, devido à perda de conhecimento específico do cliente, ao se proceder à troca do auditor. Focando seu estudo especificamente em instituições bancárias brasileiras, Dantas e Medeiros (2015), identificaram os fatores determinantes da qualidade dos trabalhos dos auditores nestas instituições utilizando como proxy de qualidade de auditoria a prática de gerenciamento de resultados, mais especificamente os accruals discricionários relacionados ao processo de constituição da Provisão para Créditos 
de Liquidação Duvidosa (PCLD). Entre outras coisas, os resultados apontaram que a qualidade dos trabalhos de auditoria tem relação negativa com a tenure a partir do sexto ano de contrato, sugerindo que o rodízio mandatório poderia ser favorável em termos de melhorar a qualidade da auditoria.

Brooks, Cheng, Johnston, e Reichelt (2013) estudaram a possibilidade de adoção de um regime de rodízio mandatório para os Estados Unidos com prazo de 10 anos, atendendo aos pedidos de estudos e comentários feito pelo PCAOB em seu concept release sobre "independência na auditoria e rodízio mandatório de firmas", (PCAOB, 2011). Neste estudo foi feita uma modelagem da qualidade da auditoria através de uma função quadrática da tenure e investigou-se, entre outras coisas, o prazo no qual a curva da qualidade atinge seu ponto máximo, passando a declinar a partir de então. Tal prazo foi estimado, para grandes empresas, em 12 anos. Também foram encontradas evidências que após a aplicação da Lei Sarbanes-Oxley o prazo onde a qualidade é máxima aumenta consideravelmente, passando para cerca de 18 anos, provavelmente indicando que tal lei teve papel decisivo em reduzir os problemas de independência no mercado norte americano. Com isto, argumentam que não foram encontradas evidências para adoção da proposta de rodízio em 10 anos. Ressalta-se haver no cenário americano o rodízio de sócios de auditoria, conforme mencionado anteriormente, porém, esta questão não é tratada.

\section{(iii) rodízio mandatório de firmas e os custos da auditoria}

Os custos atrelados ao rodízio mandatório de firmas de auditoria representam o principal argumento contra o regime. Alega-se que os custos iniciais para que um novo auditor obtenha conhecimento sobre o cliente e seu negócio são representativos. Alguns trabalhos desenvolvidos nessa linha estão apresentados a seguir.

A SDA Bocconi School of Management (2002) utilizou questionários para identificar os custos do rodízio de firmas para o auditor e para o auditado e também o impacto do rodízio nos preços de auditoria. Os respondentes dos questionários foram gerentes, auditores internos e controllers de BIG 5. Os resultados do trabalho apontaram que o rodízio aumenta os custos tanto para o auditor quando para o auditado e que os honorários recebidos no início do relacionamento com o novo cliente são inferiores aos honorários recebidos pelo auditor anterior. Estas evidências são corroboradas por um modelo desenvolvido por Arruñada e Paz-Ares (1997) que destaca o impacto que o rodízio exerce nos custos e nos preços de auditoria. De acordo com os autores os custos aumentam em relacionamentos auditor-auditado mais curtos e os custos iniciais são transferidos para os honorários de auditoria, de modo que nesse regime os honorários são mais baixos nos primeiros períodos, mas são compensados por honorários mais altos nos períodos finais. O aumento de custos também foi observado por Aninat et al. (2015) ao tratar um modelo teórico para o aumento nos custos da auditoria que seriam causados pela introdução de 
uma regra de rodízio mandatório de firmas no mercado chileno, em função de perdas no processo de aprendizagem do auditor. Considerando o caso específico da Itália, país onde o regime foi implantado, Cameran, Francis, et al. (2015), apontaram que os custos relacionados ao rodízio mandatório não são triviais, mas que poderiam ser aceitáveis caso a qualidade da auditoria fosse melhorada. No entanto, o trabalho apontou que a qualidade dos lucros auditados é menor nos primeiros anos após o rodízio, do que nos anos posteriores do mandato do auditor, o que levou os autores a terem uma opinião contrária ao rodízio mandatório.

\section{(iv) Rodízio mandatório de firmas e a competição no mercado de auditoria}

O regime de rodízio mandatório de firmas de auditoria pode causar algumas distorções na forma como o mercado de auditoria se organiza. De acordo com Cameran et al. (2005), essa regra pode modificar a competição no mercado, introduzindo distorções ou melhorias potenciais. Poucos são os trabalhos que investigam a relação entre o rodízio mandatório e a competição no mercado de auditoria, sendo que alguns deles estão apresentados a seguir.

A SDA Bocconi School of Management (2002) investigou a situação do mercado de auditoria em um país com rodízio mandatório de firmas de auditoria (Itália), a partir da aplicação de questionários. Os resultados apontaram que em uma situação com ausência da regra, a participação das firmas de auditoria no mercado não é estável, ao passo que sob o regime, a participação é estável. Assim, o rodízio mandatório aumenta a concentração de firmas no mercado, aumentando, consequentemente, a probabilidade de conluio entre auditor-auditado. Desse modo, as evidências desse estudo apontam contra o rodízio mandatório. Resultado semelhante foi obtido no modelo desenvolvido por Arruñada e Paz-Ares (1997). Projetando a participação das firmas de auditoria no mercado, sob o regime de rodízio mandatório, verificou-se que a participação das firmas pequenas é aumentada, ao passo que a participação das grandes firmas de auditoria é reduzida, até que se chega a um ponto de equilíbrio em que todas as firmas do mercado assumem igual participação. Esses resultados indicam que não há incentivos para que as firmas busquem melhorar sua eficiência, aumentando a probabilidade de conluio entre auditor-auditado. Assim, esse trabalho conclui contra o rodízio mandatório.

\section{(v) Rodízio mandatório de firmas e a reação do mercado de capitais}

A auditoria é um mecanismo cuja existência se justifica, sobretudo, para evitar problemas de assimetria de informação e de conflito de agência entre os usuários internos e externos das empresas. Nesse sentido, essa ferramenta é destacadamente importante para o mercado de capitais, que se vale das informações reportadas pela auditoria para a tomada de decisões. Sendo assim, o impacto que a regra de rodízio mandatório exerce 
no mercado é de particular importância e, embora ainda pouco estudado, já foi objeto de alguns autores, incluindo os apresentados a seguir.

A SDA Bocconi School of Management (2002) avaliou preços de ações de empresas após trocarem de firmas de auditoria e identificou aumento nos preços das ações após tais ocorrências. Porém, os autores dizem não ser possível afirmar que a elevação no valor das ações decorre especificamente da mudança de auditor. No trabalho, argumenta-se que a troca de auditoria eleva os custos, sendo mal vista pelo mercado, de modo que a conclusão final do trabalho é contrária ao rodízio mandatório. No que se refere ao valor inicial de oferta pública, Titman e Trueman (1986) e Datar, Feltham, e Hughes (1991) desenvolveram modelos nos quais este valor é apresentado como uma função crescente da qualidade da auditoria percebida. Outras pesquisas fornecem suporte de que existem consequências no mercado de capitais quando a percepção da qualidade de auditoria está comprometida por uma possível redução na independência, como é o caso dos trabalhos de Francis e Ke (2006) e Frankel et al. (2002), o que sugere que o rodízio mandatório poderia ser positivo.

O relacionamento entre características da auditoria (qualidade e prazo de relacionamento auditor-auditado) e os custos de financiamento da dívida foi o tema abordado por Mansi, Maxwell, e Miller (2004). A pesquisa foi realizada por meio de regressão estatística, onde a variável dependente foi o retorno exigido pelos investidores (spread de crédito) e as variáveis explicativas foram o tamanho da firma de auditoria, a qualidade e o prazo de relacionamento auditor-auditado. Os resultados indicaram que investidores exigem menores retornos quando a auditoria é realizada por grandes firmas e quando o prazo de relacionamento auditor-auditado é longo, evidenciando que a auditoria influencia o mercado de capitais. A conclusão do foi contra o rodízio mandatório.

Davis, Soo, e Trompeter (2009) examinaram a relação entre o prazo de relacionamento auditor-auditado e a habilidade do cliente em usar accruals discricionários para atingir o lucro previsto pelos analistas. Os resultados indicaram que tanto as firmas com curto, quanto as com longo período de relacionamento auditor-auditado, são mais propensas a reportar níveis de accruals discricionários que façam com que o lucro vá de encontro às previsões dos analistas. Os autores analisaram a situação para os períodos pré e pós Lei Sarbanes -Oxley (SOX) e identificaram que esses efeitos deixam de existir após a SOX, evidenciando que os mecanismo implementados pela referida lei foram eficazes e que não há, portanto, a necessidade de rodízio mandatório de firmas de auditoria.

Hohenfels (2016), considerando a percepção dos investidores sobre a qualidade da auditoria através do coeficiente de resposta de lucros (Earning Response Coefficient ERC) numa regressão retorno-lucro, estudou os impactos da tenure sobre a qualidade para empresas listadas na bolsa de Frankfurt. Verificou-se neste estudo uma relação não linear entre a qualidade percebida e a tenure, sugerindo que a qualidade percebida é menor nos 
anos iniciais e finais do relacionamento auditor-auditado. Estimou-se também, através de um modelo quadrático na tenure, que o período de maior qualidade percebida ocorre entre 8 e 9 anos.

A reação do mercado à eventos relacionados à possível adoção de rodízio mandatório ocorrida entre 2011 e 2013 nos Estados Unidos foi tratada por Reid e Carcello (2017). Esses autores encontraram evidência de que o mercado americano reage negativamente (positivamente) à eventos que aumentam (diminuem) a probabilidade de rodízio, embora esses resultados sejam sensíveis aos indexadores de mercado usados para calcular retornos anormais, proxy utilizada para medir a qualidade de auditoria. Testes adicionais feitos por esses autores evidenciaram ainda que a reação do mercado é mais negativa (positiva) em datas que aumentam (diminuem) a probabilidade de rodízio, dada uma tenure de auditoria mais longa. Por fim, esses autores também identificaram que a reação do mercado é mais negativa (positiva) em datas que aumentam (diminuem) a probabilidade de rotação de uma BIG N.

\section{(vi) Prazo para o rodízio mandatório de auditoria}

Como se pode notar, embora existam muitos trabalhos sobre as vantagens e desvantagens do rodízio de firmas de auditoria, quase nada foi feito até o momento no sentido de estudar qual deveria ser o prazo de relacionamento auditor-auditado a ser estabelecido como limite caso a regra seja adotada. Além disso, ressalta-se que a determinação de um prazo que maximize a qualidade média de auditoria poderia modificar o cenário apresentado, conferindo maior utilidade e respaldo à adoção do rodízio mandatório, tornando o processo de auditoria ainda mais eficaz.

Um dos poucos trabalhos encontrados foi um draft de Cheng e Zhang (2015), em que uma série de considerações sobre a modelagem da qualidade da auditoria em termos da competência e da independência são apresentadas. Os autores argumentam que a qualidade da auditoria deve ser dada pela probabilidade condicional do auditor detectar uma falha, a competência técnica, e deste reportar a falha encontrada, a independência. Assim, dadas expressões matemáticas para a probabilidade do auditor detectar uma falha e para reportála, a qualidade seria a multiplicação destas duas. Um modelo relativamente detalhado sobre o comportamento da independência em termos das quase-rendas é apresentado, porém, a parte que trata a variação temporal desta vertente não é tratada. No que tange a competência, praticamente não são feitas considerações. Com estes ingredientes os autores discutem as condições matemáticas que devem ser satisfeitas por tais funções para se observar um comportamento crescente da qualidade nos anos iniciais de relacionamento e, um comportamento decrescente nos anos finais. É apresentada, também, uma discussão de como obter um prazo ótimo para o rodízio que maximize a qualidade média da auditoria ${ }^{12}$.

$\overline{12}$ Esta discussão está apresentada na seção 3.4 e no apêndice C 
Por fim, é feita uma simulação do cenário que seria obtido caso as formas supostas para o comportamento dinâmico da competência e da independência fossem observados. Ressaltase que não foi apresentado nenhum embasamento para a forma das expressões usadas. Os autores também não realizaram testes empíricos.

Brooks et al. (2017), baseando-se em um modelo quadrático de prazo de relacionamento auditor-auditado para explicar a qualidade de auditoria, estimaram um ponto de referência que maximizaria a qualidade média da auditoria caso fosse adotado um regime de rodízio mandatório de firmas. Considerou-se uma amostra composta por vinte e dois países com diferentes regimes legais e que não adotam tal regra, confrontando níveis altos e baixos de proteção ao investidor. Os resultados desse trabalho apontaram um período ótimo mais longo em países com maior proteção ao investidor, cerca de 24 anos, comparado ao período estimado para países com baixo grau de proteção ao investidor, 14 anos. No entanto, poucas firmas da amostra seriam de fato afetadas pelo fato de haver ou não rodízio mandatório, uma vez que a maioria das empresas trocaram de auditor em períodos inferiores ao estimado, sugerindo que essa regra pode ser desnecessária. Adicionalmente, esses autores não só avaliaram a validade empírica do modelo quadrático, como utilizaram diferentes proxies de qualidade de auditoria para testar a robustez do modelo. Eles continuaram a encontrar um período ótimo para o rodízio mais longo para países com forte proteção ao investidor, implicando que uma forte proteção ao investidor, a nível de país, pode substituir curtos períodos para rodízio mandatório de firmas de auditoria.

Conforme observa-se, foi encontrado apenas um trabalho que se dedica a explicitamente obter um prazo ótimo para o regime mandatório de firmas de auditoria usando dados empíricos. Apesar de alguns trabalhos (Chi e Huang (2005), Boone, Khurana, e Raman (2008), Davis et al. (2009), Brooks et al. (2013), Hohenfels (2016)) terem usado o mesmo tipo de modelagem da qualidade da auditoria em função do tempo de relacionamento, i.e., um modelo quadrático, eles não se preocuparam em tentar estimar o prazo de rodízio. Ademais, não foi encontrado na literatura nenhum estudo que se propusesse a fazer tais estimativas ou tal tipo de modelagem para países que adotam o regime, tampouco foi encontrado estudo dedicado a este tipo de análise no mercado brasileiro. O mais próximo que observamos nesta linha foi o estudo de Dantas e Medeiros (2015), que indicou que a qualidade da auditoria, analisando somente bancos brasileiros, tem uma relação negativa a partir do sexto ano de relacionamento auditor-auditado, sem no entanto sistematizar o estudo em busca do ano a partir do qual tal relação passa a ser negativa.

Um trabalho relevante que não se encaixa nos grupos descritos, procura encontrar vieses nas opiniões a favor e contra o regime mandatório de rodízio. Neste trabalho, Casterella e Johnston (2013) analisaram as recomendações feitas na literatura acadêmica entre 2001 e 2011. A principal conclusão do trabalho é que o suporte ou não ao rodízio mandatório é altamente dependente dos dados analisados se referirem a um rodízio 
mandatório ou não. De fato, observaram que de 11 estudos avaliando um cenário onde existe o rodízio mandatório, 8 são favoráveis ao regime, enquanto dos 13 estudos que avaliaram um cenário com rodízio voluntário, apenas 2 são favoráveis. Desta forma, recomendam muita cautela ao analisar a literatura acadêmica sobre o rodízio mandatório de firmas de auditoria. 



\section{Desenho e Hipóteses de Pesquisa}

\subsection{Algumas considerações sobre a modelagem da qualidade da auditoria}

Conforme já exposto na fundamentação teórica desse trabalho, a qualidade da auditoria pode ser definida como uma função da competência técnica do auditor e de sua independência (DeAngelo, 1981a). Quando o assunto é rodízio mandatório de firmas de auditoria, os argumentos a favor e contra essa regra podem ser resumidos em dois fatores que influenciam a relação entre a qualidade da auditoria e o período de relacionamento auditor-auditado: o efeito de aprendizagem, dominante nos anos iniciais do engagement; e o efeito de familiaridade, dominante nos últimos anos (Boone et al., 2008; Chi \& Huang, 2005; Davis et al., 2009). O efeito aprendizagem aumenta a qualidade da auditoria nos primeiros anos, quando o auditor adquire novos conhecimentos sobre o setor do cliente, sobre o negócio e sobre os controles internos e, como tal, a habilidade do auditor em detectar erros aumenta. O efeito de familiaridade, por outro lado, diminui a qualidade da auditoria ao longo do tempo, devido ao crescimento do vínculo econômico entre o auditor e seu cliente, que deteriora sua independência (Brooks et al., 2017).

Após um determinado tempo de relacionamento, é natural supor que os níveis de competência e de independência se estabilizem em determinado patamar. De fato, pode-se esperar que chegará um momento em que o auditor já terá absorvido um conhecimento tal acerca da empresa auditada, de modo que precisará apenas se atualizar à medida em que sejam alteradas características inerentes ao negócio do cliente e normas e práticas de contabilidade, não ocorrendo mais um aumento material em seu nível de competência técnica, situação essa condizente com teorias de curvas de aprendizagem, vide (Chen \& Manes, 1985; Yelle, 1979). Com isto, é intuitivo se pensar que a competência técnica atingiria um patamar constante após um determinado tempo. Já o efeito de familiaridade, poderia continuar aumentando ao longo do tempo, reduzindo a independência do auditor (Corona \& Randhawa, 2010). Nesse caso, esses dois efeitos combinados resultariam no aumento da qualidade da auditoria nos primeiros anos e diminuição nos últimos anos (Brooks et al., 2017). Ou então, a independência poderia se reduzir ao longo do tempo até que fosse mantido um nível mínimo (por exemplo, em função das normas que impõe certas condições para preservar a independência), sendo que nesse outro caso, o nível da qualidade da auditoria ao longo do tempo seria determinado pelo componente que tivesse maior peso, competência ou independência.

No entanto, percebe-se que a forma como estas variáveis (competência e independên- 
cia) são combinadas em muitos estudos não retrata de maneira fiel o que se espera. De fato, a grande maioria dos trabalhos encontrados assumem que a qualidade é dada pela soma da competência técnica com a independência. Há de se notar, no entanto, que ainda que haja um altíssimo grau de competência por parte do auditor, caso a independência deste seja equivalente a zero, a qualidade da auditoria será nula, pois de nada adianta um auditor plenamente capaz de detectar possíveis falhas no cliente, caso ele não reporte essas falhas aos interessados. Por outro lado, mesmo sendo o auditor extremamente independente, isto de nada adiantará, do ponto de vista da qualidade da auditoria, se ele não tiver a competência técnica necessária para identificar possíveis problemas.

Outro problema detectado na maior parte dos modelos existentes na literatura é que, ao se propor modelos matemáticos para descrever a competência técnica e a independência dos auditores, o tempo de relacionamento auditor-auditado é tratado de forma linear. De fato, evidências encontradas na literatura apontam que o tempo de relacionamento impacta de forma positiva a competência técnica e de forma negativa a independência. Todavia, ao se considerar que tal dependência é linear, assume-se implicitamente que estas quantidades aumentam ou diminuem indefinidamente a uma mesma taxa. Pelas discussões acima quanto ao efeito de aprendizagem e ao efeito de familiaridade, nota-se claramente que a suposição de uma dependência puramente linear com o tempo de relacionamento é diferente do que se espera.

\subsection{Um modelo do impacto do tempo de relacionamento auditor- auditado (tenure) na qualidade de auditoria}

Tendo em vista o principal objetivo deste trabalho, a identificação de um prazo adequado para o rodízio de firmas de auditoria, é essencial que seja adequadamente modelado o comportamento da qualidade da auditoria, partindo do comportamento no tempo de seus componentes, competência e independência. Esse é um ponto em que o modelo proposto no presente trabalho traz inovação, pois não foi identificado na literatura trabalhos publicados que tratem o efeito do tempo de relacionamento auditor-auditado de forma isolada na competência e na independência, embora seja um consenso entre os autores que o efeito do tempo é oposto em cada uma desses componentes.

Nessa linha, o único trabalho encontrado, que não é um trabalho publicado em periódico científico, foi o de Cheng e Zhang (2015), que buscou fazer uma série de considerações matemáticas a respeito do comportamento da competência e da independência ao longo do tempo de relacionamento auditor-auditado, sem, contudo, se preocupar com a modelagem matemática embasada da relação do tempo com a competência e a independência.

Frente ao exposto, propõe-se um novo modelo que leve em consideração os pontos levantados na seção anterior (3.1). Para resolver a questão relativa à forma como a inde- 
pendência e a competência são combinadas para representar adequadamente a qualidade da auditoria, propõe-se que a relação entre esses dois componentes seja multiplicativa, assim como considerado por Cheng e Zhang (2015). Com isto, a qualidade seria baixa caso qualquer uma das grandezas, competência técnica ou independência, fosse baixa, e seria alta apenas se ambos tivessem valores consideráveis.

Como a literatura existente não fornece evidências suficientes de como a competência e a independência se comportam ao longo do tempo, para dar suporte a uma modelagem matemática, foi realizada uma consulta a um seleto grupo de profissionais com destacada experiência e com estrita relação com a auditoria independente. Essa consulta foi realizada através da aplicação de um questionário avaliando sua percepção acerca do comportamento desses componentes da qualidade da auditoria, o qual está disponível em https://goo.gl/ forms/thEhzX7GK9W1Q5Cv1 e no apêndice B. Neste questionário, são apresentadas diversas opções de comportamentos esperados destas grandezas ao longo do tempo, para que sejam marcadas pelo grupo. Os profissionais que responderam foram escolhidos por acessibilidade. O público almejado eram profissionais com cargos-chave e que com estreita relação com a auditoria das demonstrações contábeis, incluindo auditores, diretores financeiros, diretores de contabilidade, acadêmicos da área e outros. Como o acesso aos contatos de toda a população dos referidos profissionais não foi viável, foi escolhida uma amostra por acessibilidade.

O questionário foi enviado a 40 (quarenta) profissionais experientes da área e respondido por 22 desses profissionais, sendo 4 sócios de auditoria, 5 auditores gerentes, 5 acadêmicos e os demais ocupantes de cargos de gerência e direção. Ressalta-se neste ponto que, apesar de haver um pequeno número de respondentes, a lista de convidados a participar deste questionário envolvia apenas profissionais de altíssimo nível, ocupantes de cargos altos em grande empresas e diretamente ligados ao processo de auditoria. Ademais, pôde-se notar que as respostas começaram a se repetir, o que pode levar a crer que um grupo maior de respondentes conduziria a um resultado semelhante. Um detalhamento maior das respostas obtidas, assim como do questionário em si, estão apresentados no apêndice B.

No que tange ao comportamento da competência ao longo do tempo, a maioria dos respondentes $(31,8 \%)$ considera que a competência técnica do auditor aumenta a diferentes taxas, até se estabilizar em um patamar superior ao nível inicial (compatível com a Figura 1 a)), 27,3\% entendem que a competência aumenta a uma taxa crescente sem, no entanto, se estabilizar (vide Figura 1 b)) e 22,7\% entendem que ela cresce a uma taxa decrescente até se estabilizar em um patamar superior ao nível inicial (vide Figura 1 c)).

Em relação à independência do auditor, para a maioria dos respondentes $(31,8 \%)$, a independência diminui a diferentes taxas até se estabilizar em um patamar inferior ao nível 

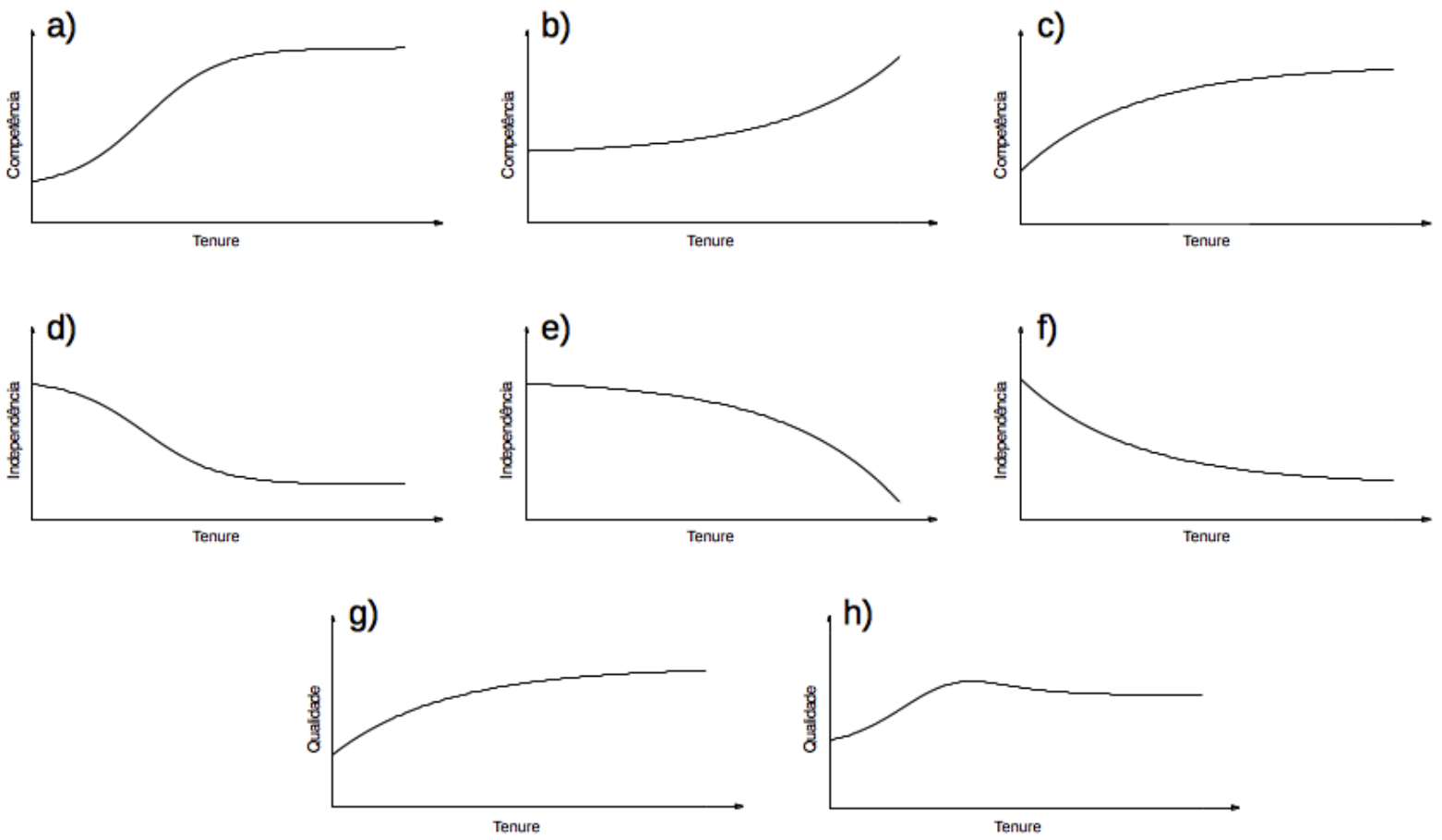

Figura 1 - Nesta figura são mostrados os comportamentos mais escolhidos no questionário aplicado. Em a), b) e c) são mostrados, respectivamente, os comportamentos escolhidos para competência técnica por 31,8\%,27,3\% e 22,7\% dos respondentes. Em d), e) e f), são mostrados os comportamentos escolhidos para independência por $31,8 \%, 22,7 \%$ e $22,7 \%$ dos respondentes, respectivamente. Em g) e h) são mostrados os comportamentos para a qualidade da auditoria escolhidos por $31,8 \%$ e $27,3 \%$ dos respondentes, respectivamente.

inicial (conforme Figura 1 d)), 22,7\% indicaram que a independência cai a taxa crescente (vide Figura 1 e)) e 22,7\% acreditam que a independência diminui a uma taxa decrescente até se estabilizar em um patamar inferior ao nível inicial (Figura $1 \mathrm{f}$ )).

Por fim, quando perguntados a respeito da qualidade da auditoria, de modo geral, $31,8 \%$ dos respondentes acreditam que a qualidade da auditoria aumenta a uma taxa decrescente até se estabilizar em um patamar superior ao nível inicial (vide Figura $1 \mathrm{~g}$ )) e $27,3 \%$ acreditam que a qualidade aumenta inicialmente e se estabiliza num patamar superior ao inicial (conforme Figura 1 h)).

Na seção seguinte, os comportamentos identificados serão traduzidos para equações matemáticas, de modo a se obter um modelo de qualidade de auditoria que retrate a percepção do mercado acerca da qualidade em si, bem como de seus componentes (competência e independência) considerados isoladamente.

\subsubsection{Modelagem matemática}

Com base na percepção do grupo de experts consultados, conforme apresentado acima, foi possível conhecer o comportamento gráfico da qualidade da auditoria e de seus 
componentes (competência técnica e independência) de forma isolada. A partir de então, pôde-se concentrar o trabalho em encontrar expressões matemáticas que descrevessem tais comportamentos, as quais estão apresentadas e discutidas nos parágrafos que se seguem.

O comportamento da competência técnica identificado pela maioria dos respondentes foi o demonstrado na Figura 1 a) (uma curva em S, geralmente chamada sigmóide), ou seja, considerou-se que a competência técnica do auditor aumenta a diferentes taxas até se estabilizar em um patamar superior ao nível inicial. Conforme já discutido anteriormente, esse comportamento é compatível com processos de aprendizagem. Tais processos são amplamente estudados, principalmente nas áreas de psicologia, engenharia e economia, sendo inclusive extensivamente utilizados na modelagem de custos e de produtividade e são frequentemente mencionados na literatura sobre qualidade da auditoria (vide DeAngelo (1981a), Mangold (1984), Knapp (1991)). Em boa parte dos casos, espera-se que a capacidade de executar uma tarefa ou o nível médio cognitivo de aprendizagem para uma determinada atividade ou ainda a proficiência em determinado assunto cresça com o tempo e se estabilize num patamar superior.

Dentre as diversas formas funcionais para se modelar curvas sigmóides, que é o caso da curva de aprendizagem e, portanto, da curva de competência, uma das principais é a função logística ${ }^{1}$, representada na Figura 1 a). Assim, a equação da competência de auditoria pode ser representada por:

$$
C O(T)=\beta_{0}+\frac{\beta_{1}}{1+e^{-\beta_{2}\left(T-\beta_{3}\right)}},
$$

onde $\beta_{0}$ representa o valor mínimo possível para competência técnica, $\left(\beta_{0}+\beta_{1}\right)$ é o valor máximo que ela pode assumir, $T$ é o tempo decorrido no relacionamento auditorauditado (tenure) e $\beta_{3}$ é o tempo de relacionamento auditor-auditado no qual a função da competência cresce à maior taxa (este tempo indica também quando a competência técnica assume um valor igual à metade do intervalo entre o valor mínimo e o valor máximo). $\beta_{2}$ é chamado declividade da curva e está relacionado à maior taxa de crescimento da competência $^{2}$, indicando quão rápido, ou quão devagar, a competência técnica atingirá seu valor assintótico máximo. O comportamento da competência ao longo da tenure pode ser observado em mais detalhes na Figura 2.

Ressalta-se o fato que, se bem observado, a Figura 1 b) e a Figura 1 c) representam, respectivamente, a primeira e a segunda metades da curva representada na 1 a), de modo que tanto a Figura 1 a), quanto sua equação correspondente, (3.2), são capazes de representar qualquer um dos 3 comportamentos mais escolhidos para competência técnica 1

$$
f(t)=\frac{A}{1+e^{-\alpha\left(t-t_{0}\right)}},
$$

onde onde $A$ representa a amplitude máxima da função, $t$ é o tempo decorrido, $t_{0}$ é o tempo no qual a função assume um valor igual à metade da amplitude máxima e $\alpha$ é a declividade da curva.

2 De fato, a inclinação máxima da curva é dada por $\beta_{1} \beta_{2} / 4$ e ocorre em $T=\beta_{3}$. 


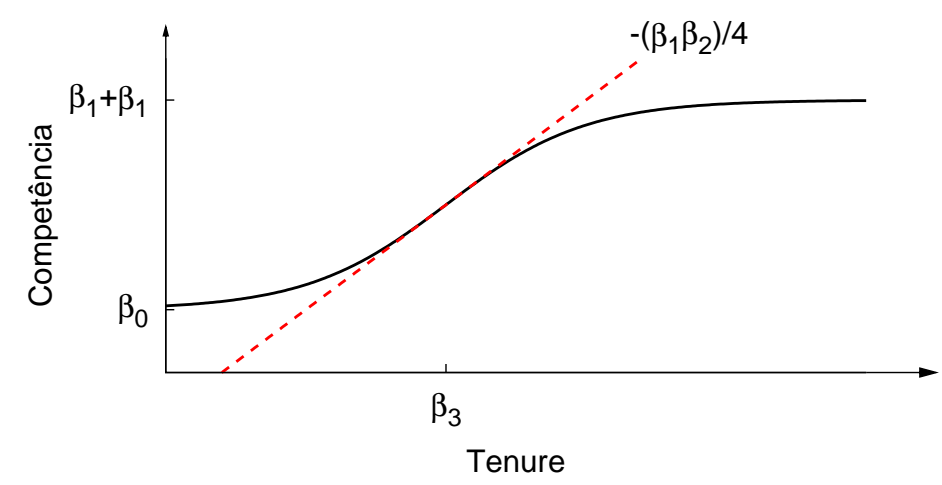

Figura 2 - Nesta figura é mostrado em mais detalhes a modelagem considerada para competência técnica. A reta tracejada indica a maior taxa de crescimento da função, que ocorrem em $\beta_{3}$

pelos respondentes do questionário. Assim, essa forma funcional é capaz de descrever o comportamento escolhido por cerca de $81,8 \%$ dos respondentes, dependendo dos valores assumidos pelos $\beta$ 's.

No que tange à modelagem da independência, não se tem, a priori, argumentos baseados no processo em si, semelhantes aos usados acima na modelagem da competência, para embasar uma escolha inicial da função modeladora. Porém, com base nas respostas colhidas no questionário, vemos que a escolha natural é por um decaimento logístico, já que novamente é capaz de descrever as opções escolhidas pela maioria $(77,2 \%)$ dos respondentes. Assim, propõem-se para a independência a seguinte forma funcional:

$$
I(T)=\gamma_{0}-\frac{\gamma_{1}}{1+e^{-\gamma_{2}\left(T-\gamma_{3}\right)}},
$$

onde, de forma semelhante, $\gamma$ 's são parâmetros que definem a dependência temporal da independência, tendo interpretações semelhantes às dadas aos $\beta$ 's da equação da competência. A única diferença nesse caso é que o sinal do segundo termo é negativo, ao invés de positivo, visto que espera-se que a independência diminua com o tempo. $\mathrm{O}$ comportamento da independência ao longo da tenure pode ser observado em mais detalhes na Figura 3.

Por fim, a qualidade de auditoria será dada pelo produto da competência pela independência, como mostrado na equação abaixo:

$$
\begin{gathered}
Q A(T)=C O(t) \times I(t) \\
Q A(T)=\left(\beta_{0}+\frac{\beta_{1}}{1+e^{-\beta_{2}\left(T-\beta_{3}\right)}}\right)\left(\gamma_{0}-\frac{\gamma_{1}}{1+e^{-\gamma_{2}\left(T-\gamma_{3}\right)}}\right) .
\end{gathered}
$$

A equação acima é capaz de descrever, dentre outras possibilidades, o comportamento esperado da qualidade da auditoria pela maior parte dos respondentes do questionário 


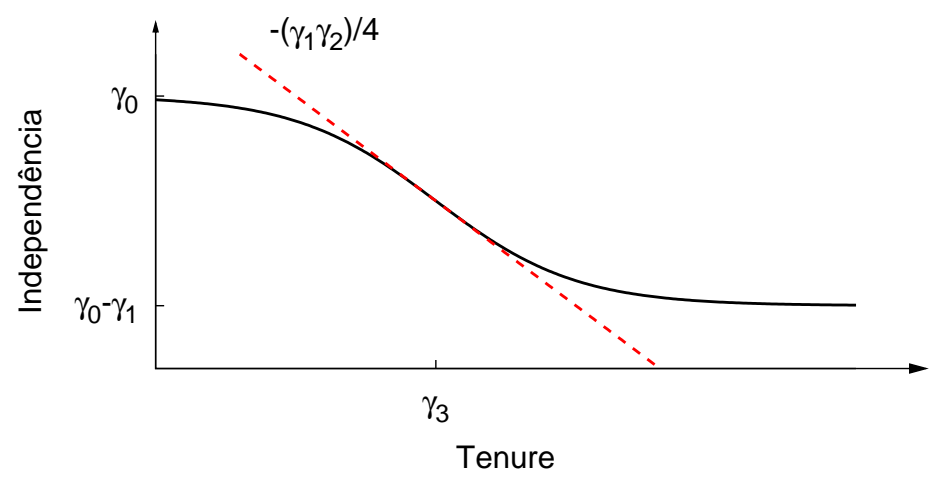

Figura 3 - Nesta figura é mostrado em mais detalhes a modelagem considerada para independência. A reta tracejada indica a maior taxa de decaimento da função, que ocorrem em $\gamma_{3}$

$(59,1 \%)$. Assim, embora o formato das curvas de competência, independência e, de forma geral, da qualidade da auditoria, venham a ser definidos, de fato, em função dos valores que os parâmetros vierem a assumir, o que se espera, em função da literatura e das respostas aos questionários, é que apresentem formas semelhantes às apresentadas nas Figuras $1 \mathrm{~g}$ ) e h). Ou seja, a qualidade cresce inicialmente e se estabiliza em um nível superior ao inicial, sendo que no caso da figura $1 \mathrm{~h}$ ) há um ponto de máximo, enquanto o mesmo não ocorre na figura $1 \mathrm{~g})$.

\subsection{Modelo alternativo}

Apesar do modelo apresentado na seção anterior ter um bom embasamento teórico e suporte no questionário aplicado, encontra-se grande dificuldade em sua aplicação empírica. O problema é que, para aplicação empírica, é necessário ajustar a função dada pela equação 3.5 aos dados obtidos. Isto implica na realização de um ajuste intrinsecamente não linear, uma vez que a equação 3.5 não pode ser linearizada. Devido ao fato do modelo conter um número elevado de parâmetros (ao todo são 8) e dos dados disponíveis não apresentarem um período suficientemente longo, a estimação desse modelo, no contexto atual, é bastante complexa. Apesar de diversas tentativas, no presente trabalho, não foi possível lograr êxito em sua estimação, muito porque ajustes não lineares, como o que se apresenta, são feitos de forma iterativa ${ }^{3}$ (Gujarati \& Porter, 2011), acontecendo muitas vezes do modelo não convergir, ou convergir para um ponto inadequado, sendo necessário tentar outros valores para os parâmetros iniciais até se obter a convergência esperada.

3 Por ser um processo iterativo, ajustes não lineares são altamente sensíveis à escolha inicial dos parâmetros a serem ajustados. Com isto, a robustez frente a variações nos valores iniciais é altamente desejável e indicativo de um bom ajuste. 
No caso presente, observou-se que a convergência poderia carecer de muitas tentativas mais, além do fato de que também esse problema poderia ser decorrente dos dados das atuais proxies de qualidade de auditoria disponíveis não serem bem comportados, e do fato de que, no caso brasileiro, devido à vigência da regra de rodízio mandatório de firmas de auditoria, não se dispor de longos períodos de relacionamento auditor-auditado para facilitar a convergência.

Frente a estas considerações, para viabilizar a aplicação do modelo ao caso brasileiro, foi necessário fazer a simplificação exposta na seção a seguir.

\subsubsection{Modelo quadrático}

Uma das formas frequentemente usadas para se simplificar uma função não linear é expandi-la em uma série de potências (Chiang, 2008). Este tipo de simplificação fornece estimativas da função original no entorno de um dado ponto, cuja concordância com a função original aumenta com a quantidade de termos mantidos na expansão. Assim, a partir de uma expansão em série é gerado um polinômio de grau $n$ que visa aproximar o valor da função original num dado intervalo. No presente caso, pode-se utilizar este método para reescrever a equação da qualidade da auditoria como um polinômio considerando a variável tenure. A partir de uma expansão até segunda ordem, tem-se:

$$
Q A=\alpha_{0}+\alpha_{1} T+\alpha_{2} T^{2}
$$

onde $\alpha_{0}, \alpha_{1}$ e $\alpha_{2}$ são constantes construídas a partir dos parâmetros da equação inicial $(3.5)$.

A equação 3.6 é uma simplificação da equação 3.5, tratando agora a relação da qualidade da auditoria com o tempo de relacionamento auditor-auditado (tenure) como uma função quadrática. Esse tipo de modelo já foi empregado na literatura em alguns trabalhos, como é o caso de Chi e Huang (2005), Boone et al. (2008), Davis et al. (2009), Hohenfels (2016) e Brooks et al. (2017). Uma desvantagem desta abordagem é que ela não permite separar as contribuições individuais do aumento da competência técnica e da diminuição da independência, impedindo assim a identificação dos fatores que mais poderiam influenciar o tempo adequado para o rodízio de auditoria. Por outro lado, esta é uma expressão simples o bastante para permitir a utilização das técnicas econométricas menos complexas, uma vez que esta expressão é linear nos parâmetros ( $\alpha$ 's), permitindo inclusive a realização de regressões lineares simples.

Recentemente, Brooks et al. (2017) utilizaram esse modelo quadrático para estudar o prazo ótimo para o rodízio de firmas de auditoria em países com diferentes regimes legais e que não utilizam rodízio mandatório de firmas de auditoria. Nesse trabalho os autores avaliaram a validade empírica deste modelo e determinaram um ponto de referência, no qual a qualidade média de auditoria pode ser maximizada. 


\subsection{Obtendo um prazo ótimo para o rodízio}

Cheng e Zhang (2015) e Brooks et al. (2017) propõem que, ao se usar o modelo quadrático apresentado na seção anterior, desconsiderando os custos da troca, é possível encontrar um ponto de referência, no qual a troca de auditor maximiza a qualidade média da auditoria, sendo possível demonstrar que esse ponto seria igual a 3/2 do ponto máximo da função 3.6.
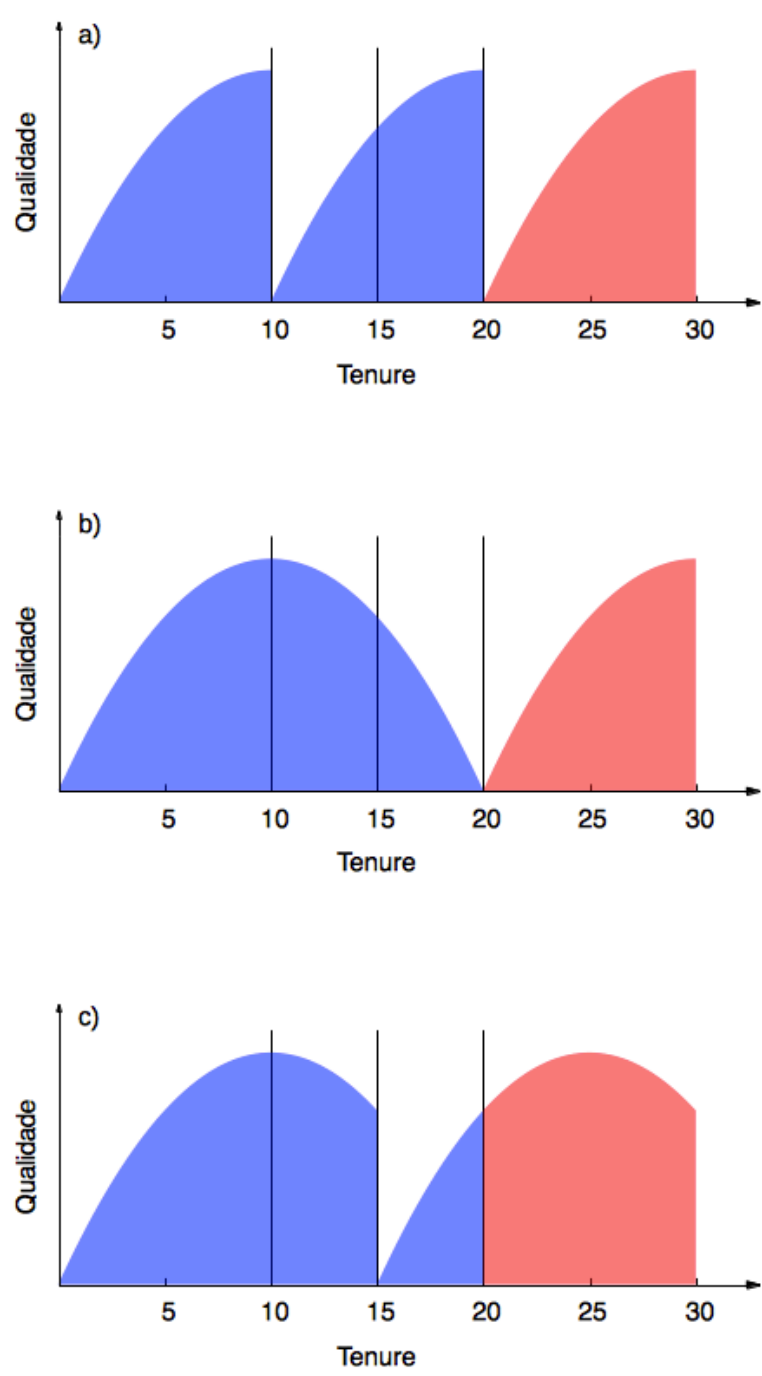

Figura 4 - Nesta figura, baseada em figura similar apresentada no trabalho de Brooks et al. (2017), são ilustradas três opções diferentes para o prazo de rodízio considerando um comportamento quadrático para qualidade. Em a) o rodízio ocorre no ponto de qualidade máxima; em b) no ponto onde a qualidade retorna ao nível inicial e em c) a troca é feita no ponto de referência. Como pode ser visto, este último maximiza a qualidade média, ou seja, para o período total ilustrado, esta é a situação em que a área total sob a curva da qualidade é máxima.

Esses autores fazem uma discussão, ilustrada através da Figura 4, que demonstra bem como a substituição da firma de auditoria no ponto de referência maximiza a qualidade 
da auditoria no longo prazo. A Figura 4 a) mostra uma situação em que o cliente troca seu auditor no ponto máximo da curva de qualidade e a qualidade da auditoria cai imediatamente para o nível inicial com um novo auditor começando seu engagement. A Figura 4 b) mostra que a substituição do auditor no ponto em que a qualidade da auditoria atinge novamente seu valor inicial (após ter passado pelo seu ponto máximo e começado a decrescer) não resultando numa quebra abrupta da qualidade da auditoria, pois o seu sucessor irá iniciar com o mesmo nível de qualidade que o antecessor mantinha quando encerrou seu engagement, porém esse será o mais baixo nível até então. Por fim, a Figura 4 c) ilustra a troca do auditor no ponto de referência. Como se pode notar, esse ponto apresenta a maior qualidade de auditoria cumulativa (considerando todos os engagements), de modo que esse ponto pode ser considerado "ótimo" para que ocorra o rodízio da firma de auditoria.

A obtenção do ponto de referência, bem como dos pontos de máximo e do ponto onde a qualidade de auditoria alcança novamente seu valor inicial, está apresentada no Apêndice C, que segue os trabalhos de Cheng e Zhang (2015) e Brooks et al. (2017). Esses valores são:

Ponto máximo da curva de qualidade da auditoria: $\tau=\frac{-\alpha_{1}}{2 \alpha_{2}}$

Ponto em que a qualidade assume novamente seu valor inicial: $2 \tau$

Ponto em que a qualidade média assume seu maior valor (ponto de referência): $\frac{3}{2} \tau$

Com base nessa discussão, é possível assumir que, a partir do modelo quadrático proposto na seção anterior, o ponto "ótimo" para que os reguladores utilizem como base para o rodízio mandatório de firmas de auditoria é, de fato, o ponto de referência.

\subsection{Operacionalização do modelo quadrático}

De acordo com Martins e Theóphilo (2007), para que seja possível a aplicação empírica de um modelo teórico, antes é necessário traduzir a abstração da teoria para a situação real que se apresenta, através de pontes que permitam a operacionalização de tal modelo.

Desse modo, para que seja possível estudar o efeito do tempo de relacionamento auditor-auditado na qualidade da auditoria por meio do modelo quadrático apresentado na seção 3.3.1, é preciso operacionalizar construtos para viabilizar sua aplicação ao caso brasileiro, bem como se definir proxies para representar as principais variáveis do modelo. Seguindo esse raciocínio, a equação básica de teste (baseada na equação 3.6) utilizada nessa tese pode ser observada a seguir:

$$
\begin{aligned}
I Q U A & =\beta_{0} T E N U R E+\beta_{1} T E N U R E^{2}+\beta_{2} B I G N+\beta_{3} E S P E C+\beta_{4} L E V \\
& +\beta_{5} C O N C+\beta_{6} W E D G E
\end{aligned}
$$


onde:

- IQUA - é o índice de qualidade das auditorias proposto por Braunbeck (2010), considerado de forma invertida;

- TENURE - é o período de relacionamento entre auditor-auditado em um mesmo engagement, expresso em número de anos consecutivos, contados a partir de 1998. Esta variável busca captar o efeito dos primeiros anos de relacionamento auditorauditado na qualidade da auditoria;

- TENURE $E^{2}$ - é o valor de TENURE elevado ao quadrado. Esta variável busca captar o efeito de longos períodos de relacionamento auditor-auditado na qualidade da auditoria, assim como a não linearidade existente;

- BIGN - é uma variável dummy que assume o valor 1 caso a firma de auditoria seja uma Big $\mathrm{N}^{4}, 0$ caso contrário;

- ESPEC - Razão entre a receita líquida da empresa num dado setor dividido pela receita líquida total deste setor;

- $L E V$ - Razão entre a dívida bruta total da empresa e seu patrimônio líquido;

- $C O N C$ - Concentração do capital votante, mensurada como a participação dos 3 maiores acionistas no capital votante da empresa;

- WEDGE - Dissociação entre os interesses de propriedade e interesses sobre fluxos de caixa, mensurado como a diferença entre $C O N C$ e a participação no capital total dos 3 maiores acionistas;

O índice IQU A, proposto por Braunbeck (2010), considerado de forma invertida, foi escolhido como proxy da qualidade de auditoria por mensurar essa grandeza de forma mais abrangente, utilizando não apenas uma métrica, mas um conjunto de métricas baseadas, sobretudo, no processo de auditoria. Conforme discutido na seção 2.2.3 da fundamentação teórica, esse indicador se baseia em 8 perguntas, todas relacionadas a situações que afetam a qualidade da auditoria, portanto é um indicador multifatorial, visto que considera diversos aspectos que impactam a qualidade. Dessa maneira, entende-se que é uma proxy mais completa. Além disso, Braunbeck (2010) defende que o IQUA permite uma avaliação singular da qualidade da auditoria no Brasil por, pelo menos, outras 4 razões:

- é construído com base em informações públicas;

- os elementos que compõem esse índice possuem caráter objetivo;

4 Seguindo a literatura foram consideradas como Big N as firmas de auditoria Arthur Andersen (até 2012), Deloitte Touche Tohmatsu, Ernst \& Young, KPMG e PricewaterhouseCoopers. 
- o banco de dados construído nesse trabalho e nos trabalhos de Braunbeck (2010) e Luccas (2015), cobre parcela substancial das empresas com ações listadas na Bovespa em um período de 19 anos;

A única diferença em relação à aplicação do $I Q U A$ como proposto inicialmente por Braunbeck (2010) é que, no presente trabalho, utiliza-se seu valor invertido. O IQUA originalmente proposto é um índice que, quanto maior seu valor numérico, menor a qualidade estimada da auditoria avaliada. Assim, quando o IQUA assume valor 8, indica o pior nível de qualidade de auditoria e, quando assume o valor 0, indica o melhor. Desse modo, neste trabalho inverte-se a aplicação de Braunbeck (2010), atribuindo valor 0 ao pior nível de auditoria e valor 8 ao melhor nível de auditoria ${ }^{5}$. Isso será feito porque, para que as análises descritas anteriormente façam sentido, é preciso que a proxy escolhida seja diretamente proporcional à qualidade da auditoria.

O tempo de relacionamento auditor-auditado (TENURE) é uma variável diretamente observável, bastando apenas contar o número de anos consecutivos que a firma de auditoria permanece com o mesmo cliente, através das informações anuais publicadas pelas companhias abertas. Como o primeiro ano dessas informações disponível online na Central de Sistemas da CVM é 1998, para o cálculo da TENURE considerou-se esse como o primeiro ano de relacionamento entre auditor-auditado.

Além das variáveis principais do modelo (IQUA, TENURE e TENURE ${ }^{2}$ ), foram incluídas outras variáveis para controlar os efeitos na qualidade da auditoria que não podem ser completamente explicados pelo tempo de relacionamento auditor-auditado. Para controle, foram escolhidas as variáveis utilizadas por Braunbeck (2010) no seu estudo sobre determinantes da qualidade de auditoria. Braunbeck (2010) estabeleceu proxies para as variáveis teóricas do modelo de Arruñada (1997), acrescendo uma variável (ESPEC) para captar os efeitos da competência técnica, visto que Arruñada (1997) modelou apenas a independência de auditoria. Segue uma breve descrição de cada uma dessas variáveis de controle.

As variáveis $C O N C$ e $W E D G E$ foram incluídas para captar os efeitos do oportunismo e do conflito de agência na independência e, portanto, na qualidade da auditoria. Elas tratam da concentração de capital $(C O N C)$ e da separação de direitos de controle e de participação nos fluxos de caixa $(W E D G E)$. Com base na literatura nacional e internacional de governança corporativa, considera-se que quanto maiores forem a concentração de capital e a separação dos direitos de controle e propriedade, maiores serão os conflitos de interesse entre controladores e não controladores (vide Shleifer e Vishny (1997)

5 Para se alcançar esse resultado, basta trocar a valor das respostas, em cada uma das questões que compõe o IQUA (vide seção 2.2.3), de maneira a se obter o comportamento desejado. Dessa forma, ao invés de atribuir 1 para as respostas afirmativas e 0 para as respostas negativas, atribui-se 0 para as afirmativas e 1 para as negativas, o que é equivalente a fazer 8 menos o valor obtido da forma originalmente proposta. 
e Leal (2004)) e, portanto, mais sujeito estará o auditor a pressão, podendo prejudicar sua independência.

A variável $L E V$ foi incluída para captar o risco de deterioração financeira de uma empresa, através de um indicador de endividamento e estrutura de capital, que permite avaliar o grau de comprometimento financeiro. De acordo com Arruñada (1997), um dos mais importantes componentes do grau de independência do auditor é o seu julgamento sobre a possibilidade de que a situação financeira de seu cliente se deteriore de tal forma, que o auditor se veja envolvido em um caso de grande repercussão, comprometendo sua reputação. Nesse caso, quando a situação financeira do cliente não está satisfatória, o auditor tende a ser mais independente, aumentando o nível da qualidade da auditoria (Braunbeck, 2010).

A inclusão da variável de controle $B I G N$ se baseia na vasta literatura (incluindo, DeAngelo (1981b), Dye (1993), Almeida e Almeida (2009), Braunbeck (2010), Harris (2012), Brooks et al. (2017), Reid e Carcello (2017)) que estuda os impactos da auditoria ser feita por uma das chamadas "Big N" na qualidade da auditoria. Isso porque, devido ao seu porte, essas firmas têm muito mais quase-rendas de clientes, ativos de forma geral e probabilidade de ter contingências futuras por responsabilidade profissional a enfrentar. Desse modo, espera-se que essas firmas adotem postura mais independente, o que incrementa a qualidade das auditorias prestadas por elas (Braunbeck, 2010).

Por fim, a variável ESPEC capta a participação de mercado do auditor em um determinado setor, ou seja, sua especialização. A especialização, segundo Braunbeck (2010), pode representar a capacitação técnica que o auditor desenvolve por se dedicar tanto a determinado setor, trazendo com isso, incremento na qualidade da sua auditoria.

\subsection{Hipóteses de pesquisa}

A seguir estão apresentadas 3 hipóteses de pesquisa que serão testadas no próximo capítulo.

\section{$\mathbf{H}_{1}$ : A qualidade da auditoria é uma função crescente do tempo de relaciona- mento auditor-auditado nos anos iniciais do engagement.}

Com base em toda discussão feita até este ponto e levando-se em conta a vasta literatura que dá suporte a este pressuposto básico, esta constitui uma hipótese base para esse trabalho, ou seja, todo resto baseia-se na sua verificação. De fato, caso não houvesse um aumento inicial na qualidade da auditoria, não faria sentido manter um auditor numa empresa, já que a cada troca haveria um incremento na qualidade. A base teórica que suporta essa hipótese é o fato do tempo de relacionamento auditor-auditado aumentar a 
competência técnica do auditor, aumentando assim a qualidade. Esta hipótese implica num sinal positivo de $\beta_{0}$ na equação 3.7 .

\section{$\mathbf{H}_{2}$ : No longo prazo, a qualidade da auditoria tende a diminuir com o tempo de relacionamento auditor-auditado.}

Esta segunda hipótese já representa uma questão mais delicada sobre a qual o debate em torno do regime de rodízio mandatório de firmas de auditoria se concentra e envolve dois conceitos. Primeiramente, assim como todo processo de aprendizado, espera-se que a competência técnica cresça até atingir um patamar constante no longo prazo, o que implica na diminuição da taxa de crescimento da qualidade da auditoria, sem contudo indicar, isoladamente, uma redução no nível de qualidade. Por outro lado, com o modelo quadrático, espera-se que o efeito familiaridade continue aumentando ao longo do tempo, reduzindo a independência do auditor, de modo que, esses dois efeitos combinados resultem no aumento da qualidade da auditoria nos primeiros anos e na diminuição nos últimos anos. Para que, de fato, ocorra essa redução da qualidade da auditoria nos últimos anos, é preciso que a qualidade tenha um ponto máximo dentro do período estudado para então começar a decrescer. Assim, por essa hipótese, espera-se que o o coeficiente $\beta_{1}$ seja negativo, indicando que a curva da qualidade da auditoria tem um formato de U invertido, ou seja, tem um ponto máximo.

\section{$\mathrm{H}_{3}$ : É possível estimar um tempo "ótimo" para o rodízio mandatório de firmas de auditoria.}

Finalmente, essa última hipótese se refere especificamente ao objetivo central deste trabalho e trata da verificação conjunta das hipóteses 1 e 2, pois apenas no caso de ambas serem verdadeiras, ou seja, apenas se a qualidade realmente for crescente nos anos iniciais e começar a decrescer após um determinado tempo observável em nossa amostra, um regime de rodízio mandatório se justifica e um prazo "ótimo" pode ser estimado. Necessita-se, então, para sua verificação, que $\beta_{0}$ seja positivo e $\beta_{1}$ negativo, conjuntamente.

Com base nas hipóteses levantadas acima e em comportamentos esperados para os sinais dos demais coeficientes da equação básica de teste (equação 3.7), especialmente as considerações feitas no trabalho de Braunbeck (2010), apresentamos na Tabela 3 uma síntese dos sinais esperados para os coeficientes. 
Tabela 3 - Resumo dos sinais esperados para os coeficientes da equação 3.7

\begin{tabular}{lcc}
\hline Variável independente & Sinal esperado do coeficiente & Hipótese \\
\hline TENURE & + & $\mathrm{H}_{1}$ e $\mathrm{H}_{3}$ \\
TENURE & - & $\mathrm{H}_{2}$ e $\mathrm{H}_{3}$ \\
$B I G N$ & + & Variável de controle \\
$E S P E C$ & + & Variável de controle \\
$L E V$ & + & Variável de controle \\
$C O N C$ & - & Variável de controle \\
WEDGE & - & Variável de controle \\
\hline
\end{tabular}





\section{Análise empírica}

Neste capítulo será apresentada a aplicação empírica do modelo descrito no capítulo anterior assim como testes de robustez do resultado obtido.

\subsection{Amostra}

A amostra utilizada é composta por empresas de capital aberto com ações negociadas na BOVESPA nos exercícios fiscais compreendidos no período de 1998 a 2016, excluindo-se empresas dos setores "Finanças e Seguros" e "Fundos" de acordo com a classificação do banco de dados ECONOMATICA ${ }^{\circledR}$. O início da análise em 1998 justifica-se por este ser o primeiro exercício para o qual as informações das Demonstrações Financeiras Padronizadas (DFP) passaram a ser disponibilizadas em meio eletrônico pela Central de Sistemas da CVM. Conforme determina o artigo 16 da Instrução 202 de 6 de dezembro de 1993, cabe às companhias o arquivamento periódico de suas demonstrações contábeis anuais, acompanhadas do relatório da administração e do parecer dos auditores independentes, cujo conjunto compõe as chamadas DFP's, dentro da nomenclatura dos formulários de preenchimento obrigatório pelas companhias abertas no Brasil. A exclusão dos setores "Finanças e Seguros" e "Fundos" se deve ao fato de empresas destes setores terem características próprias diferenciadas e, por serem sujeitas a órgãos reguladores específicos, possuem normas próprias para a substituição de auditores independentes, o que torna seus contextos bastante particulares frente ao cenário das demais companhias abertas. Na Tabela 4, descreve-se as fontes de onde foram obtidos os dados para cada um dos grupos de variáveis utilizadas.

Cabe ressaltar que, para se obter os dados descritos nas três primeiras linhas da Tabela 4, foram analisados 8.919 pareceres de auditores independentes. Destes, 4.198 são referentes ao período de 1998 a 2008 e foram compilados por Braunbeck (2010), 1.401 são referentes ao período de 2009 a 2012 e foram compilados por Luccas (2015) e os 3.320 restantes, referentes ao período 2013 a 2016, foram compilados pela autora. Ao todo, neste estudo, foram inicialmente selecionadas 672 empresas, contabilizando um total de 12768 observações no período de 1998 a 2016. No entanto, muitas destas observações não contém dados devido a fatores como determinada empresa não ser listada em alguns anos ou alguma informação contábil necessária na determinação de alguma variável de interesse não estar disponível na base de dados consultada (ECONOMATICA $\left.{ }^{\circledR}\right)$. Isto levou à diferenças no número total de observações utilizadas para cada uma das proxies de qualidade da auditoria consideradas na análise empírica central e nos testes de robustez, e que serão expostas oportunamente. 
Tabela 4 - Fontes de dados para o teste empírico

\begin{tabular}{|l|l|}
\hline Variável & Fonte de informação \\
\hline$I Q U A$ & $\begin{array}{l}\text { Os dados referentes ao período entre } 1998 \text { e } 2008 \text { foram obtidos do } \\
\text { banco de dados proprietário compilado por Braunbeck (2010). Os dados } \\
\text { referentes ao período de } 2009 \text { a } 2012 \text { foram obtidos do banco de dados } \\
\text { proprietário compilado por Luccas (2015). Os dados referentes ao período } \\
\text { de } 2013 \text { a } 2016 \text { foram compilados pela autora. Em todos os casos, as } \\
\text { questões relativas ao parecer dos auditores independentes foram respon- } \\
\text { didas com base na leitura dos pareceres dos auditores independentes } \\
\text { disponibilizadas nas DFP's acessadas por meio da página web da CVM } \\
\text { (<www. cvm.gov. br>) em diversas datas. Para as questões relativas à } \\
\text { republicação ou a processos administrativos também utilizou-se a página } \\
\text { da CVM. As informações relativas às empresas insolventes foram obtidas } \\
\text { através do Boletim Diário de Informações da BOVESPA e do Cadastro } \\
\text { da CVM. }\end{array}$ \\
\hline Obtido através da contagem do número de anos consecutivos em que \\
um mesmo auditor independente foi responsável pelas DFP's publicadas \\
e disponibilizadas no site da CVM.
\end{tabular}

Encerrando a apresentação dos dados, na Tabela 5, está apresentado um sumário estatístico das variáveis utilizadas nesse trabalho ${ }^{1}$.

Tabela 5 - Estatística descritiva das variáveis utilizadas no ajuste quadrático do IQUA.

\begin{tabular}{lcccc}
\hline Variáveis & Média & Desvio-Padrão & Min & Max \\
\hline IQUA & 7,386 & 0,705 & 4 & 8 \\
TENURE & 2,670 & 1,542 & 1 & 7 \\
TENURE & 9,504 & 10,18 & 1 & 49 \\
CONC & 0,788 & 0,213 & 0,00139 & 1 \\
WEDGE & 0,122 & 0,174 & $-0,754$ & 0,994 \\
BIGN & 0,650 & 0,477 & 0 & 1 \\
ESPEC & 0,0503 & 0,104 & 0 & 0,651 \\
LEV & 0,835 & 2,145 & $-5,020$ & 15,15 \\
\hline
\end{tabular}

1 As variáveis relacionadas a informações contábeis, ESPEC e $L E V$, foram winsorizadas nos percentis 1 e 99 . O processo de winsorização no $1^{\circ}$ e $99^{\circ}$ percentis consiste em substituir os valores menores que o do $1^{\circ}$ percentil pelo valor do $1^{\circ}$ percentil e os valores maiores que o do $99^{\circ}$ percentil pelo do $99^{\circ}$ percentil, numa tentativa de se excluir outliers espúrios da amostra sem, contudo, reduzí-la. É um método padrão em análises estatísticas para tratar a existência de outliers. 


\subsection{Resultados Principais}

Nesta seção são apresentados os resultados obtidos através da utilização do modelo básico (equação 3.7, página 74) descrito na seção 3.5 do capítulo 3 . Na Tabela 6, a seguir, estão apresentados os resultados de uma regressão robusta pelo método de mínimos quadrados ordinários $(\mathrm{MQO})$ da referida equação ${ }^{2}$.

Tabela 6 - Resultado do ajuste por MQO robusto de acordo com a equação 3.7.

\begin{tabular}{lccc}
\hline Variáveis & Valor & Erro padrão & $t$ \\
\hline TENURE & 1.936 & 0,041 & $47,51^{* * *}$ \\
TENURE & -0.255 & 0,008 & $-35,27^{* * *}$ \\
BIGN & 1.015 & 0,037 & $27,29^{* * *}$ \\
$E S P E C$ & 1.810 & 0,166 & $10,89^{* * *}$ \\
$L E V$ & 0.019 & 0,009 & $2,27^{* *}$ \\
$C O N C$ & 4.634 & 0,061 & $75.72^{* * *}$ \\
$W E D G E$ & -0.140 & 0,099 & -1.41 \\
& & & \\
$\boldsymbol{\tau}$ & $\mathbf{3 , 8 0 0}$ & $\mathbf{0 , 0 3 6}$ & $\mathbf{1 0 1 , 6 8 * * \dagger}$ \\
$\mathbf{T}_{\mathbf{R}}^{*}$ & $\mathbf{5 , 7 0 1}$ & $\mathbf{0 , 0 5 6}$ & $\mathbf{1 0 1 , 6 8 * * \dagger}$ \\
& & & \\
Observações & 6.521 & & \\
R-quadrado & 0,96 & & \\
*** p<0,01, ${ }^{* *} \mathrm{p}<0,05, * \mathrm{p}<0,1$ & \\
$\dagger$ - teste $z$. & & &
\end{tabular}

Como pode-se observar, as variáveis de maior interesse apresentaram os sinais esperados. Em especial, uma vez que $\beta_{0}>0$, o coeficiente relacionado à tenure, confirma-se a primeira hipótese levantada, $\mathrm{H}_{1}$, ou seja, que a qualidade da auditoria aumenta nos anos iniciais do relacionamento auditor-auditado. Como o coeficiente relacionado à TENURE ${ }^{2}$, $\beta_{1}$, é menor que zero, verifica-se que a segunda hipótese também é verdadeira, ou seja, que a qualidade da auditoria passa a deteriorar-se em longos períodos de tempo, de modo que a curva da qualidade apresenta um ponto máximo. Como ambas as hipóteses foram verificadas, pode-se concluir que o modelo quadrático é aplicável ao caso brasileiro, assim como verificado por Brooks et al. (2017) para outros 22 países que não utilizam o rodízio mandatório de firmas de auditoria, analisados em blocos de acordo com o regime legal adotado. E o mais importante, os sinais obtidos por esses coeficientes evidencia que é possível se estimar um prazo "ótimo" para o rodízio de firmas de auditoria, confirmando assim a terceira hipótese desse estudo.

2 No que se refere à qualidade da regressão realizada, verificamos que apesar de testes para normalidade de resíduos (teste de Shapiro-Wilk, por exemplo) não terem indicado normalidade dos resíduos, o que pode ser esperado devido ao grande tamanho da amostra, a inspeção visual do histograma de resíduos e dos gráficos Q-Q e P-P indicam normalidade. A possível existência de multicolinearidade foi testada pelo fator de inflação da variância (VIF), não sendo identificados problemas nesse sentido. Apenas as variáveis TENURE e TENURE $E^{2}$ apresentam colinearidade, conforme esperado. Problemas de heterocedasticidade foram tratados pela utilização de erros robustos na regressão. 
Sendo assim, na Tabela 6 também são mostrados, em negrito, os valores obtidos para o período onde a qualidade da auditoria no Brasil é máxima, $\tau$, e o prazo "ótimo" para rodízio das firmas de auditoria, $T_{R}^{*}$, conforme considerações feitas na seção 3.4 do capítulo 3. Os resultados evidenciam, portanto, um prazo "ótimo" de 5,7 anos. Este resultado indica que o prazo atualmente utilizado pela CVM, 5 anos, é compatível com o alcance do nível máximo de qualidade média de auditoria, considerada de modo geral, ou seja, considerando os vários engagements sucessivos existentes em um longo período de tempo. Um ponto relevante é o fato do ponto de qualidade máxima $(\approx 4$ anos) estar claramente dentro do intervalo onde há um grande número de observações, o que dá maior suporte estatístico à queda na qualidade da auditoria que leva ao prazo estimado.

Quanto às demais variáveis, observa-se que o coeficiente relacionado à variável $B I G N$ tem o sinal esperado e significância estatística, confirmando o comportamento observado em diversos estudos realizados no Brasil (e.g., Almeida e Almeida (2009) e Braunbeck (2010)) e ao redor do mundo (e.g., Harris (2012), Brooks et al. (2017), Reid e Carcello (2017) ), que empresas auditadas por firmas de auditoria Big-N apresentam uma maior qualidade da auditoria. Também significativos e com sinais esperados foram os coeficientes relacionados às variáveis ESPEC e $L E V$. O primeiro reforça a ideia de que auditores com maior especialização (i.e., mais competentes tecnicamente) estão associados a auditorias de maior qualidade, o que se expressou na estimativa de coeficiente significativo e positivo. Já o segundo relaciona-se à expectativa de que empresas com maior endividamento estão mais propensas a apresentar problemas financeiros futuros, levando o auditor a ter maior rigor em sua análise com vistas a evitar se envolver num caso que possa abalar sua imagem e reputação. Por fim, o coeficiente da variável $C O N C$ apresentou sinal contrário ao esperado e o da variável $W E D G E$ não foi significativo.

O comportamento inesperado das variáveis $C O N C$ e $W E D G E$ pode estar atrelado ao fato da relação da governança corporativa com a teoria da agência ter se alterado ao longo do tempo. Embora a literatura de governança corporativa considere que quanto maiores forem a concentração de capital e a separação dos direitos de controle e propriedade, maiores serão os conflitos de interesse entre controladores e não controladores, esta relação pode ter se modificado com o avanço dos mecanismo de governança, por exemplo, conselhos fiscais, comitês de auditoria, regulação, etc., sendo indicativo da necessidade de futuros estudos. Ademais, esse comportamento inesperado não trouxe preocupação no caso deste trabalho, a princípio, devido ao fato dessa variável ter sido incluída apenas como controle e também porque, num teste estimando o modelo com a exclusão dessas variáveis (veja a Tabela 12, no apêndice D), observou-se que os resultados não divergem substancialmente dos resultados originais. De fato, apesar de haver diferenças nos coeficientes de TENURE e de $T E N U R E^{2}$, a razão entre eles, que fornece os períodos de qualidade máxima e, consequentemente, o prazo "ótimo", praticamente não se modificou. 
Tentou-se ainda analisar o modelo em questão através da inclusão de outras variáveis de controle. Dummies relacionadas a setores econômicos e anos foram incluídas, no entanto, o resultado obtido não diferiu significativamente dos resultados apresentados acima. Considerando que a inclusão de tantas dummies diminui os graus de liberdade, optamos pelo modelo enxuto.

\subsection{Testes de robustez}

Com vistas a testar a robustez dos resultados obtidos acima, foram utilizadas proxies alternativas de qualidade de auditoria para verificar se isso afetaria, de forma relevante, o prazo "ótimo" apurado para o rodízio mandatório de firmas brasileiras de auditoria.

Buscou-se, então, medidas amplamente utilizadas na literatura de qualidade da auditoria, como as medidas baseadas em métricas contábeis (mais especificamente, relacionadas a gerenciamento de resultados). Nesse sentido, foram eleitas duas medidas alternativas: uma em que a qualidade da auditoria pudesse ser estimada individualmente para cada observação, a saber, os accruals discricionários obtidos de acordo com o modelo de Francis e Wang (2008), apresentados na seção 2.2.3; e uma segunda medida em que apenas a qualidade média relacionada a cada período de relacionamento auditor-auditado pudesse ser aferida, como é o caso da variabilidade de resultados obtida através dos resíduos da equação 2.5, também apresentada na referida seção. Vide mais detalhes sobre essas métricas a seguir.

\subsubsection{Accruals discricionários}

Seguindo uma vasta literatura de trabalhos que utilizam accruals discricionários como medida de qualidade de auditoria (e.g., entre vários outros, V. Johnson et al. (2002), Myers et al. (2003), Harris e Whisenant (2012) e Silvestre, Costa, e Kronbauer (2017)), será agora utilizada como medida de qualidade de auditoria, a qualidade dos accruals.

A Tabela 7 apresenta um sumário estatístico relacionado às variáveis utilizadas nesta parte do estudo ${ }^{3}$. Como pode ser observado, o número de observações é diferente do utilizado para o $I Q U A$ em virtude da ausência de algumas informações contábeis necessárias para o cálculo dos accruals discricionários. A variável $Q A_{a c c}$, que é uma proxy para qualidade da auditoria, foi obtida multiplicando-se -1 pelo valor absoluto dos accruals discricionários, $A b A c c$, obtidos através da equação 2.4, apresentada na página 35. Isto se deve ao fato de que, quanto maiores forem os valores apurados para os accruals discricionários, maior será a estimativa de gerenciamento de resultados, pouco importando

3 As variáveis relacionadas a informações contábeis, $Q A_{a c c}, E S P E C$ e $L E V$ foram winsorizadas nos percentis 1 e 99 
se tais valores são positivos ou negativos. Ademais, quanto maior for o gerenciamento apurado, menor será a qualidade da auditoria. Com isto, altos valores de $|A b A c c|$ estão relacionados à baixa qualidade de auditoria, de forma que a relação de proporcionalidade entre a qualidade e o valor que a representa é obtido ao fazer $Q A_{a c c}=-|A b A c c|$.

Tabela 7 - Estatística descritiva das variáveis utilizadas no teste de robustez a partir de accruals discricionários.

\begin{tabular}{lcccc}
\hline Variáveis & Média & Desvio-Padrão & Min & Max \\
\hline$Q A_{a c c}$ & $-0,145$ & 0,213 & $-1,410$ & $-0,00116$ \\
TENURE & 2,847 & 1,612 & 1 & 8 \\
TENURE & 10,70 & 11,35 & 1 & 64 \\
BIGN & 0,687 & 0,464 & 0 & 1 \\
CONC & 0,766 & 0,217 & 0,00139 & 1 \\
$W E D G E$ & 0,135 & 0,177 & $-0,695$ & 0,994 \\
ESPEC & 0,0575 & 0,107 & $9,15 \mathrm{e}-06$ & 0,631 \\
LEV & 0,923 & 2,225 & $-5,009$ & 15,71 \\
& & & & \\
Observações & 4.799 & & & \\
\hline
\end{tabular}

De posse destas variáveis, foi realizado um ajuste por MQO robusto de acordo com a seguinte equação:

$$
\begin{aligned}
Q A_{a c c} & =\beta_{0} T E N U R E+\beta_{1} T E N U R E^{2}+\beta_{2} B I G N+\beta_{3} E S P E C+\beta_{4} L E V \\
& +\beta_{5} C O N C+\beta_{6} W E D G E,
\end{aligned}
$$

que, exceto pela troca de $I Q U A$ por $Q A_{a c c}$, é igual à equação 3.7, ou seja, considerou-se as mesmas variáveis explicativas, incluindo as de controle, sendo trocada apenas a proxy de qualidade de auditoria. Os resultados desta regressão são mostrados na Tabela 8. Como pode ser visto, obtivemos o sinal esperado e significância estatística para o coeficiente relacionado à variável TENURE. Apesar do coeficiente obtido para variável TENURE não ter apresentado significância estatística de forma isolada, seu sinal é o esperado e, o prazo ótimo estimado a partir destes coeficientes, $T_{R}^{*}$, que é o objetivo maior deste trabalho, apresentou significância estatística ao nível de $1 \%$. Considera-se com isto que este resultado traz robustez à estimativa apresentada anteriormente, já que o resultado obtido através desta outra proxy não é substancialmente divergente do obtido anteriormente, considerando o erro padrão associado a esta estimativa. Deve-se mencionar ainda o fato de que accruals discricionários são notadamente sensíveis a fatores não necessariamente incorporados nas variáveis de controle utilizadas, e que seus valores são proporcionalmente mais dispersos que os do $I Q U A$, como pode ser averiguado a partir do desvio padrão normalizado pela média, que fornece o valor 0,0095 para o $I Q U A$ frente a 1,47 para $Q A_{a c c}$. 
Tabela 8 - Resultado do ajuste por MQO robusto dos accruals discricionários obtidos do modelo de Francis e Wang (2008) pela equação 4.1.

\begin{tabular}{|c|c|c|c|}
\hline Variáveis & Valor & Erro padrão & $t$ \\
\hline TENURE & 0,013 & 0,007 & $10,97^{* *}$ \\
\hline$T E N U R E^{2}$ & $-0,001$ & 0,001 & $-10,25$ \\
\hline$B I G N$ & 0,046 & 0,008 & $60,17 * * *$ \\
\hline$E S P E C$ & 0,106 & 0,023 & $40,51^{* * *}$ \\
\hline$L E V$ & 0,005 & 0,001 & $30,62^{* * *}$ \\
\hline$C O N C$ & $-0,050$ & 0,013 & $-30,70 * * *$ \\
\hline$W E D G E$ & $-0,078$ & 0,022 & $-30,50 * * *$ \\
\hline Const & $-0,165$ & 0,015 & $-100,85^{* * *}$ \\
\hline$\tau$ & 5.857 & 1,999 & $2,93 * * * \dagger$ \\
\hline $\mathbf{T}_{\mathbf{R}}^{*}$ & 8.786 & 2,999 & $2,93 * * * \dagger$ \\
\hline Observações & 4.799 & & \\
\hline R-quadrado & 0,035 & & \\
\hline
\end{tabular}

\subsubsection{Variabilidade nos lucros líquidos}

O segundo teste de robustez empregado está baseado na análise da variabilidade nos lucros líquidos como indícios de suavização de resultados, de forma semelhante à feita por Harris (2012). A ideia é que esforços para suavizar resultados podem ser capturados pela variância dos resíduos de uma regressão feita de acordo com a equação 2.5, apresentada na página 36. Com isto, a amostra foi dividida em grupos de acordo com o tempo de relacionamento auditor-auditado (tenure) e, a regressão foi feita apenas com as observações de um dado grupo, ou seja, para cada período da tenure foi feita uma regressão. Assim, foi possível obter estimativas da qualidade de auditoria média para cada valor de tenure. A Tabela 9 apresenta o sumário estatístico das variáveis usadas nas regressões ${ }^{4}$. Já os resultados das regressões feitas para cada grupo, ou seja, para cada valor da tenure, são apresentados no apêndice D.2.

Conforme já discutido na seção 2.2.3, quanto maior a variância dos resíduos da regressão pela equação 2.5 (página 36), menor a qualidade da auditoria. Usou-se, então, o inverso da variância dos resíduos como proxy da qualidade da auditoria $(Q A=1 / \sigma)$. Na Tabela 10, é mostrada a qualidade da auditoria, assim obtida, para cada valor de tenure. Na última coluna é mostrado também o resultado de uma integração numérica da qualidade dividida pelo período de relacionamento, ou seja, um cálculo numérico da equação

$$
\frac{\int_{0}^{T_{R}} Q A(T) d T}{T_{R}},
$$

4 Novamente as variáveis relacionadas a informações contábeis, $\triangle N I, S I Z E$, GROWTH, LEV $V_{H}$, $D I S S U E, A T O$ e $C F O$ foram winsorizadas nos percentis 1 e 99 
Tabela 9 - Estatística descritiva das variáveis utilizadas no teste de robustez a partir da variabilidade nos lucros líquidos.

\begin{tabular}{lcccc}
\hline Variáveis & Média & Desvio-Padrão & Min & Max \\
\hline$\Delta N I$ & $-0,0161$ & 0,711 & $-4,432$ & 3,939 \\
SIZE & 12,92 & 2,155 & 6,163 & 17,35 \\
GROWTH & 0,142 & 0,494 & $-0,973$ & 3,069 \\
EISSUE & 0,149 & 0,356 & 0 & 1 \\
LEVH & 1,801 & 5,874 & $-16,75$ & 41,24 \\
$D I S S U E$ & 0,249 & 0,850 & $-0,922$ & 6,416 \\
ATO & 0,646 & 0,577 & 0 & 3,171 \\
CFO & $-0,0338$ & 0,710 & -6 & 0,903 \\
BIGN & 0,638 & 0,481 & 0 & 1 \\
& & & & \\
Observações & 5.706 & & & \\
\hline
\end{tabular}

que representa a qualidade média de um engagement de $T_{R}$ anos. Note que a qualidade média assim definida é a soma da qualidade durante todo o período de vigência deste engagement, representada pela integral, dividida pelo período durante o qual esse valor foi acumulado, $T_{R}$, da mesma forma que calcula-se qualquer média (mais detalhes sobre esse tipo de cálculo podem ser vistos no Apêndice E). Como pode ser notado, a qualidade média atinge um valor máximo para 6 anos de engagement, estando em linha com os resultados obtidos pela análise do IQUA e dos accruals discricionários. Perceba, no entanto, que a presente análise não se baseou num modelo específico para o comportamento da qualidade da auditoria ao longo do tempo, como o modelo quadrático utilizado nas análises anteriores. De fato, a única limitação imposta foi que houvesse um número mínimo de 40 observações para se realizar o ajuste e assim obter a variância dos resíduos, o que limitou as observações a 7 anos de tenure. Na figura 5, ilustramos o comportamento obtido através de um gráfico.

Tabela 10 - Resultados da análise de suavização de resultados nos lucros líquidos.

\begin{tabular}{cccccc}
\hline Tenure & Qualidade & Erro padrão & $z$ & $P>|z|$ & Qualidade média \\
\hline 1 & 6.60 & 0.79 & 8.34 & 0.00 & 3.30 \\
2 & 10.98 & 4.43 & 2.48 & 0.01 & 6.04 \\
3 & 7.62 & 1.81 & 4.22 & 0.00 & 7.13 \\
4 & 8.42 & 3.47 & 2.42 & 0.02 & 7.35 \\
5 & 8.57 & 2.78 & 3.08 & 0.00 & 7.58 \\
6 & 7.58 & 2.65 & 2.86 & 0.00 & 7.66 \\
7 & 4.23 & 2.47 & 1.72 & 0.09 & 7.24 \\
\hline
\end{tabular}




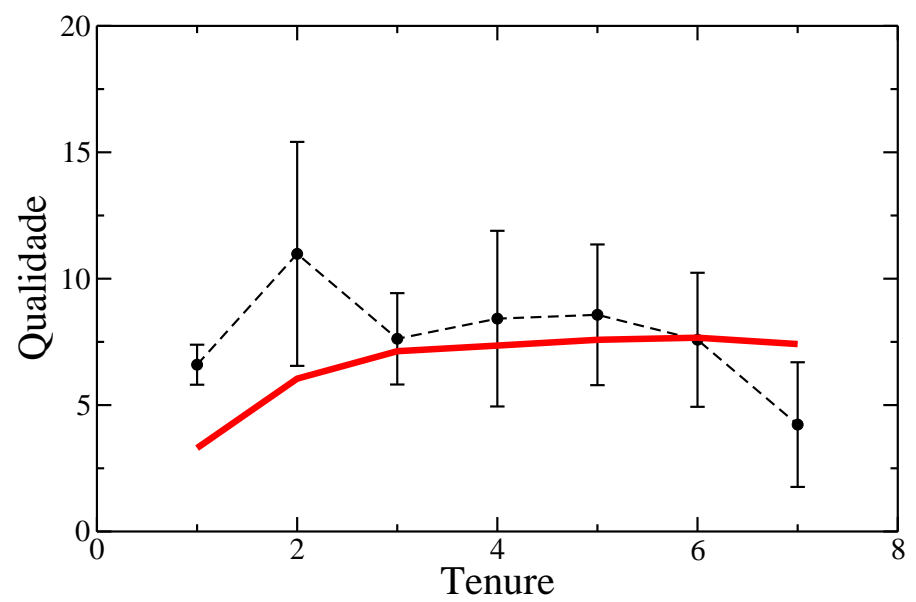

Figura 5 - Gráfico da qualidade da auditoria em função da tenure. Os pontos pretos representam a qualidade da auditoria com seu respectivo erro padrão associado. A curva sólida é a qualidade média definida pela equação 4.2 que foi obtida numericamente. Ou seja, é a integral da curva preta divida pelo número de períodos. 



\section{Conclusões e perspectivas}

Neste trabalho estabeleceu-se, pela primeira vez, uma proposta de um prazo "ótimo" para o regime de rodízio mandatório de firmas de auditoria no Brasil. Esta é uma questão de especial interesse para reguladores de mercado, dada a escassez de estudos nessa linha, além de ter impactos sobre toda discussão acerca da adoção da regra. Ressalta-se, no entanto, que este trabalho não busca trazer argumentos a favor ou contra o regime mandatório de firmas de auditoria. O objetivo é, simplesmente, estimar o prazo "ótimo" para o rodízio num cenário onde ele é adotado. Conforme já discutido, o regime mandatório foi instituído com vistas a reduzir o impacto negativo sobre a qualidade das auditorias independentes, advindo de uma esperada perda de independência por parte do auditor, que o levaria a não reportar possíveis problemas encontrados. Através da aplicação empírica de um modelo que incorpora os principais pressupostos acerca do impacto do tempo de relacionamento auditor-auditado (tenure) na qualidade de auditoria, estimou-se que o prazo "ótimo" para o rodízio de firmas de auditoria no Brasil é 5,7 anos, corroborando o que já é adotado pela CVM.

Para se chegar à análise empírica foi necessário antes tecer considerações sobre a modelagem matemática do impacto da tenure sobre a qualidade da auditoria. De fato, conforme apresentado nos capítulos 2 e 3, há uma grande quantidade de trabalhos que se dedicam a identificar os principais determinantes da qualidade da auditoria e a verificar se o regime de rodízio mandatório realmente se justifica. No entanto, há poucos trabalhos dedicados a estudar a dinâmica do comportamento da qualidade de auditoria ao longo do tempo, considerando isoladamente suas vertentes competência e independência. Mais especificamente, uma modelagem matemática adequada do impacto do tempo de relacionamento auditor-auditado na qualidade através de suas vertentes é pouco considerada. A maioria dos trabalhos nessa linha se dedicam a explicar os determinantes da qualidade da auditoria, tratando de forma única o efeito da tenure nesta, embora considerem teoricamente que existe um efeito concorrente da tenure sobre esses componentes: o aumento da competência técnica do auditor ao longo do tempo, e a redução na qualidade devido à perda de independência advinda do relacionamento cada vez mais próximo do auditor com o cliente. Tal separação de efeitos não é levada em conta na maioria das modelagens feitas. Aqui, procurou-se, com base na percepção de um seleto grupo de profissionais e acadêmicos da área e em considerações gerais quanto à natureza destes fatores, formular um modelo matemático que segregasse as contribuições da competência e da independência, apresentando uma relação mais adequada com o tempo de relacionamento auditor-auditado que a comumente utilizada (relação linear). Observou-se, no entanto, que esta é uma tarefa muito mais complexa que se pôde imaginar 
incialmente. O modelo, apesar de bem embasado, resultou em expressões matemáticas não lineares de difícil aplicação empírica devido à sua complexidade. Soma-se a isto o fato de as proxies para qualidade da auditoria estarem sujeitas a uma série de outros fatores, não necessariamente relacionados ao processo de auditoria, e, por isso, não serem bem comportadas, no sentido de produzir variações suaves e diretamente relacionadas às variações na qualidade da auditoria. Considera-se, no entanto, que as considerações e formulações aqui apresentadas, apesar de não terem tido aplicação explícita no presente trabalho, contribuem de forma significativa para literatura, podendo embasar formulações futuras capazes de avaliar separadamente as contribuições de cada um destes fatores.

Com vistas a mitigar os problemas encontrados ao se tentar fazer a aplicação empírica do modelo não linear, que segrega os papéis da competência técnica e da independência, propôs-se utilizar uma simplificação do modelo original, a saber, um modelo quadrático. Além de constituir uma aproximação em segunda ordem do modelo original, tal tipo de análise também foi utilizada em estudos recentes na literatura (Boone et al., 2008; Brooks et al., 2013, 2017; Chi \& Huang, 2005; Davis et al., 2009; Hohenfels, 2016). Com esta modelagem dos impactos do tempo de relacionamento sobre a qualidade da auditoria, foi possível realizar a aplicação empírica, através de regressões lineares, que permitiram obter um prazo "ótimo" para o rodízio ao se maximizar a qualidade média da auditoria. Primeiramente considerou-se como proxy da qualidade da auditoria o índice IQUA, desenvolvido por Braunbeck (2010) e utilizou-se como variáveis de controle, variáveis explicativas utilizadas por esse mesmo autor. Os resultados da regressão são mostrados na Tabela 6 . Tais resultados corroboram as hipóteses de pesquisa descritas na seção 3.6, a saber: $\mathrm{H}_{1}$ de que nos anos iniciais do relacionamento auditor-auditado a qualidade da auditoria aumenta, implicando num sinal positivo para o coeficiente relacionado à variável TENURE; $\mathrm{H}_{2}$ de que no longo prazo a qualidade da auditoria passa a diminuir, implicando num sinal negativo do coeficiente relacionado ao quadrado da tenure (TENURE ${ }^{2}$ ); e, $\mathrm{H}_{3}$ que o modelo quadrático pode ser aplicado ao caso brasileiro e, portanto, um prazo ótimo para o rodízio de auditoria pode ser estimado. Deveras, o prazo estimado foi de 5,7 anos.

Para trazer robustez ao resultado encontrado, estimou-se também o prazo "ótimo" com base em outra proxy para qualidade da auditoria, os accruals discricionários do modelo de Francis e Wang (2008). Tal análise corrobora o resultado encontrado anteriormente, fornecendo um prazo de 8,8 anos, pouco maior que o anterior, mas sujeito a um erro estatístico maior. Outro teste de robustez empregado foi uma análise da suavização de lucros líquidos similar à empregada por Harris (2012). Nesta análise, ao invés de fazer uma regressão para obter os coeficientes que levam à qualidade média num dado engagement, foram usadas as variâncias dos resíduos de regressões para se obter a qualidade de auditoria para cada tenure. A partir destas estimativas, foi feita uma integração numérica direta da qualidade de auditoria em função da tenure, a fim de obter a qualidade média de um engagement com um dado número de anos. Assim, o prazo que resultou no maior 
nível de qualidade média de auditoria foi 6 anos, corroborando novamente os resultados encontrados.

Deve-se levar em conta o fato que os prazos aqui estimados consideram apenas o impacto do tempo de relacionamento auditor-auditado na qualidade da auditoria, sem levar em consideração outros fatores como os custos relacionados à troca de auditor. Tal estimativa é particularmente útil do ponto de vista dos usuários das demonstrações financeiras, pois estes almejam obter as informações mais precisas possíveis, buscando, portanto, uma qualidade máxima para auditoria. No entanto, pode ser que do ponto de vista do mercado, seja interessante promover uma redução de custos às custas de uma qualidade de auditoria pouco menor que a ótima, mas estas considerações estão fora do escopo desse trabalho.

Ademais, é importante frisar novamente que a imperfeição intrínseca às proxies utilizadas para representar a qualidade da auditoria pode ser um fator limitante dos ajustes estatísticos, levando a ajustes não ideais, podendo ter impacto tanto nos valores obtidos quanto em seus erros estatísticos. Outra limitação importante a se destacar é que, tratando-se de um sistema dinâmico, é natural imaginarmos que a própria existência do rodízio de firmas tenha um papel determinante no prazo ótimo que se estabelece. Assim, a resposta natural dos agentes de mercado à existência da regra pode levar a uma autoadaptação que resulta num prazo similar ao estabelecido. No entanto, mais estudos são necessários para se verificar esta hipótese.

Comparando os resultados obtidos neste trabalho com os obtidos por Brooks et al. (2017), 14 anos para países com um regime legal que oferece baixo grau de proteção a investidores e 24 anos para países com alto grau de proteção, percebe-se que os prazos obtidos para estes outros países foram significantemente maiores. Há de se observar, no entanto, que isso é compreensível devido às peculiaridades do sistema de governança corporativa de cada país e, sobretudo, devido a diferenças nas regulações para assegurar a qualidade de auditoria (e.g., no trabalho de Brooks et al. (2017) foram estudados apenas países em que o rodízio mandatório de firmas de auditoria não vigora; além disso, muitos deles utilizam o rodízio de sócios e outras regras de proteção à independência, diferentes das utilizadas no Brasil). De fato, a existência de outras regulamentações de preservação da qualidade de auditoria podem alterar sobremaneira o efeito da tenure na qualidade. Além disso, é importante destacar que os referidos autores estimaram prazos médios para vários países que se enquadraram em um mesmo regime legal, sem particularizar o prazo país a país.

De toda forma, uma vez que o prazo estimado é um pouco superior a 5 anos e nos testes de robustez foram encontrados prazos também maiores que 5 anos, acredita-se que um leve aumento no prazo de rodízio atual poderia não trazer prejuízos aos usuários das demonstrações contábeis, apresentando uma qualidade média de auditoria essencialmente 
igual. Ademais, tal aumento no prazo poderia ser benéfico ao mercado por, possivelmente, minimizar os efeitos dos custos iniciais de auditoria (start up costs). No entanto, uma análise pormenorizada destas possibilidades fogem ao escopo do presente trabalho sendo deixadas para estudos futuros ou para consideração do órgão regulador.

Dentre as diversas possibilidades de estudos futuros advindos deste trabalho destacam-se as seguintes:

1) Identificação de proxies mais adequadas a análises similares às feitas aqui. Percebeu-se na execução deste trabalho, que as diversas proxies usadas na literatura, em especial as relacionadas à obtenção de accruals discricionários, estão sujeitas à grandes flutuações, advindas não só de variações na qualidade das auditorias. Tais flutuações dificultam o uso de modelos mais elaborados e sensíveis aos dados, impedindo assim uma modelagem mais realista da qualidade da auditoria. Com isto, a obtenção de proxies mais bem comportadas e suaves pode ter grande impacto nas pesquisas realizadas na área. É evidente que esta não é uma tarefa fácil, mas suspeitamos que combinações de diferentes proxies possam reduzir substancialmente tais flutuações.

2) Formulação de modelos mais simplificados que sejam capazes de segregar as contribuições da competência técnica e da independência. A grande vantagem de se fazer tal formulação seria identificar o peso que cada uma desempenha no estabelecimento de um prazo ótimo. Isto poderia levar reguladores a propor medidas mais voltadas a determinada vertente com vistas a aumentar a qualidade do processo de auditoria como um todo. Algumas possibilidades vem sendo formuladas, como a apresentada na seção 3.2 desse trabalho, sendo o maior empecilho encontrado na aplicação, a identificação de métodos estatísticos adequados e a inexistência de proxies mais bem comportadas para qualidade da auditoria. 3) Incorporação do custo da auditoria nas análises. O presente estudo não levou em consideração os impactos em termos de custos advindos dos diferentes prazos de rodízio. A incorporação deste fator tende a tornar as estimativas de prazos ideais mais realistas e condizentes com a situação observada no mercado brasileiro. Tendo em vista que a publicação dos honorários de auditoria passou a ser obrigatória após a instrução CVM n ${ }^{\circ}$ 480 de 2009, tal tipo de estudo pode se mostrar factível em um futuro próximo. 


\section{Referências}

Afify, H. (2009). Determinants of audit report lag: Does implementing corporate governance have any impact? empirical evidence from egypt. Journal of Applied Accounting Research, 10(1), 56-86.

Akerlof, G. A. (1970, Agosto). The market for "lemons": quality uncertainty and the market mechanism. The Quartely Journal of Economics, 84 (3), 488-500.

Al-Khoury, A. F., Ali, A., Al-Sharif, M., Hanania, J., Al-Malki, I., \& Jallad, M. (2015). Auditor Independence and Mandatory Auditor Rotation in Jordan. International Business Research, 8(4), 73-82.

Almeida, J., \& Almeida, J. (2009). Auditoria e earnings management: estudo empírico nas empresas abertas auditadas pelas big four e demais firmas de auditoria. Revista Contabilidade 6 Finanças, 20(50).

Almutairi, A. R., Dunn, K. A., \& Skantz, T. (2009). Auditor tenure, auditor specialization, and information asymmetry. Managerial Auditing Journal, 24(7), 600-623.

American Institute of Certified Public Accountants (AICPA). (1978). Commission on auditors responsibilities (cohen commission), report, conclusions, and recommendations (Professional Standards). New York, NY.

American Institute of Certified Public Accountants (AICPA). (1985). Inflation targeting and macroeconomic stability in a post keynesian economy (Vol. B; Professional Standards). New York, NY.

André, P., Broye, G., Pong, C., \& Schatt, A. (2016). Are joint audits associated with higher audit fees? European Accounting Review, 25(2), 245-274.

Angelo, D. I. (2006). Coordenação de obras públicas federais: a performance dos contratos fiscalizados em função dos custos de mensuração dos serviços e a probabilidade de existência de hold up. In 40 simpósio fucape de produção científica. Fucape Business School. Disponível em http://www.fucape.br/_public/producao_cientifica/ 2/angelo\%20-\%20coordenacao $\% 20$ de $\% 20$ obras $\% 20$ publicas.pdf

Aninat, A., Bustos, A., \& Riutort, J. (2015). The effect of rotation among audit firms: an event study in Chile (Relatório Técnico).

Arruñada, B. (1997). La calidad de la auditoría: incentivos privados y regulación. Madrid: Marcial Pons.

Arruñada, B. (2000). Audit quality: attributes, private safeguards and the role of regulation. The European Accounting Review, 9 (2), 205-224.

Arruñada, B., \& Paz-Ares, C. (1997). Mandatory rotation of company auditors: A critical examination. International Review of Law and Economics, 17(1), 31-61.

Ashbaugh, H. (2001). Non-us firms' accounting standard choices. Journal of Accounting 
and Public Policy, 20(2), 129 - 153.

Ashton, R. H., Willingham, J. J., \& Elliott, R. K. (1987). An empirical analysis of audit delay. Journal of Accounting Research, 25(2), 275-292.

Assaf Neto, A. (2009). Finanças corporativas e valor. São Paulo: Atlas.

Assunção, J., \& Carrasco, V. (2008). Avaliação da rotatividade dos auditores independentes (Relatório Técnico). Rio de Janeiro.

Azevedo, F. B. (2007). Efeito da troca de firma de auditoria no gerenciamento de resultados das companhias abertas brasileiras (Mestrado). Instituto Capixaba de Pesquisas em Contabilidade, Economia e Finanças (FUCAPE), Espírito Santo.

Azevedo, F. B., \& Costa, F. M. d. (2012). Efeito da troca da firma de auditoria no gerenciamento de resultados das companhias abertas brasileiras. Revista de Administração Mackenzie, 13(5), 65-100.

Balsam, S., Krishnam, J., \& Yang, J. S. (2003). Audit industry specialization and earnings quality. Auditing: a journal of practice \&5 theory, 22, 71-97.

Bamber, E., \& Iyer, V. (2007). Auditors' identification with their clients and its effect on auditors' objectivity. Auditing: A Journal of Practice 85 Theory, 26 (2), 1-24.

Bates, H., Ingram, R., \& Reckers, M. (1982, Abril). Auditor-client affiliation: the impact on materiality ( a study of the effect of auditor rotation on materiality judgments). Journal of Accountancy, 60-63.

Bauer, T. (2013). The effects of client identity strength and professional identity salience on auditor judgements., Working Paper.

Bauer, T. (2015, janeiro). The effects of client identity strength and professional identity salience on auditor judments. The Accounting Review, 90(1), 95-114.

Bedard, J., \& Johnstone, K. (2010). Audit partner tenure and audit planning and pricing. Auditing: A Journal of Practice \& Theory, 29(2), 45-70.

Behn, B. K., Choi, J.-H., \& Kang, T. (2008). Audit quality and properties of analyst earnings forecasts. The Accounting Review, 83(2), 327-349.

Boone, J. P., Khurana, I. K., \& Raman, K. K. (2008). Audit firm tenure and the equity risk premium. Journal of Accounting, Auditing and Finance(23), 115-140.

Braunbeck, G. O. (2010). Determinantes da qualidade das auditorias independentes no brasil (Doutorado). Universidade de São Paulo, São Paulo.

Brooks, L. L. Z., Cheng, C. S. A., Johnston, J. A., \& Reichelt, K. J. (2013, Setembro). Audit firm tenure and audit quality: Evidence from u.s. firms. Pullman: Washington State University, Working Paper.

Brooks, L. L. Z., Cheng, C. S. A., Johnston, J. A., \& Reichelt, K. J. (2017). Estimates of optimal audit firm tenure across different legal regimes. Journal of Accounting, Auditing and Finance, 32(1), 3-39.

Burden, R. L., \& Faires, J. D. (2008). Análise numérica. Cengage Learning.

Cameran, M., Di Vincenzo, D., \& Merlotit, E. (2005). The audit firm rotation rule: A review 
of the literature (Research Paper). SDA Bocconi School of Management. Disponível em http://papers.ssrn.com/sol3/papers.cfm?abstract_id=825404

Cameran, M., Francis, J. R., Marra, A., \& Angela, P. (2015). Are There Adverse Consequences of Mandatory Auditor Rotation? Evidence from the Italian Experience. Auditing: a Journal of Practice \& Theory, 34(1), 1-24.

Cameran, M., Negri, G., \& Pettinicchio, A. (2015). The audit mandatory rotation rule: the state of the art. Journal of Financial Perspectives, 3(2), 61-75.

Caramanis, C., \& Lennox, C. (2008). Audit effort and earnings management. Journal of Accounting and Economics, 45(1), 116 - 138.

Carcello, J., \& Nagy, A. (2004, Setembro). Audit firm tenure and fraudolent financial reporting. Auditing: A Journal of Practice \& Theory, 23(2), 55-69.

Carey, P., \& Simnett, R. (2006). Audit partner tenure and audit quality. The Accounting Review, 81(3), 653-676.

Carson, E. (2009). Industry specialization by global audit firms networks. The Accounting Review, 84(2), 355-382.

Carvalho, F. J. C. d., Souza, F. E. P. d., Sicsú, J., Paula, L. F. R. d., \& Studart, R. (2002). Economia monetária e financeira: Teoria e prática. Rio de Janeiro: Campus.

Casterella, J. R., \& Johnston, D. (2013). Can the academic literature contribute to the debate over mandatory audit firm rotation? Research in Accounting Regulation, 25(1), 108-116.

Catanach, A. H., \& Walker, P. L. (1999). The international debate over mandatory auditor rotation: a conceptual research framework. Journal of International Accounting, Auditing and Taxation, 8(1), 43-66.

Chen, J. T., \& Manes, R. P. (1985). Distinguishing the two forms of the constant percentage learning curve model. Contemporary Accounting Research(1), 242-252.

Cheng, C. S. A., \& Zhang, T. (2015, fevereiro). On the Optimal Year of Auditor Rotation (Relatório Técnico No. Abril). Disponível em http://papers.ssrn.com/sol3/ papers.cfm?abstract_id=2565651

Chi, W., \& Huang, H. (2005). Discretionary accruals, audit-firm tenure and audit-partner tenure: empirical evidence from Taiwan. Journal of Contemporary Accounting and Economics(1), 65-92.

Chiang, A. (2008). Matematica para economistas. Pearson.

Chung, H. (2004, outubro). Selective mandatory auditor rotation and audit quality: an empirical investigation of auditor designation policy in korea., Working Paper.

Church, B. K., \& Zhang, P. (2006, janeiro). A model of mandatory auditor rotation. , Working Paper. Disponível em http://papers.ssrn.com/sol3/papers . cfm?abstract _id=874884

Comissão de Valores Mobiliários. (1999). Instrução CVM no 308/1999. Recuperado em 09 setembro 2017, de file:///C:/Users/patri/Downloads/deli549consolid 
.pdf (Acessado: 09 set. 2017)

Comissão de Valores Mobiliários. (2008). Deliberação CVM no 549/2008. Recuperado em 09 setembro 2017, de file:///C:/Users/patri/Downloads/deli549consolid .pdf (Acessado: 09 set. 2017)

Comissão de Valores Mobiliários. (2011). Instrução CVM no 509/2011. Recuperado em 09 setembro 2017, de file:///C:/Users/patri/Downloads/inst509.pdf (Acessado: 09 set. 2017)

Comissão de Valores Mobiliários (CVM). (2017). Cadastro Geral da CVM. Recuperado em setembro 2017, de http://sistemas.cvm.gov.br/?CadGeral (Acessado: 15 ago. 2017)

Copley, P., \& Doucet, M. (1993, Fall). Auditor tenure, fixed fee contracts, and the supply of substandard single audits. Public Budgeting \& Finance, 13(3), 23-36.

Corona, C., \& Randhawa, R. S. (2010). The auditor's slippery slope: an analysis of reputational incentives. Management Sciense(56), 924-937.

Cunha, P. R. d., Morás, V. R., \& Leite, M. (2015). Efeito da troca da firma de auditoria no gerenciamento de resultados das companhias abertas brasileiras. In Congresso ufsc de controladoria e finanças. Universidade Federal de Santa Catarina. Disponível em http://dvl.ccn.ufsc.br/congresso_internacional/anais/6CCF/44_17.pdf

Daniels, B. W., \& Booker, Q. (2011). The effects of audit firm rotation on perceived auditor independence and audit quality. Research in Accounting Regulation, 23, $78-82$.

Dantas, J. A., \& Medeiros, O. R. D. (2015). Determinantes de Qualidade da Auditoria Independente em Bancos. Revista Contabilidade \& Finanças, 1-14.

Dao, M., HassabElnaby, H. R., \& Said, A. (2015). The impact of audit committee and shareholder activism on the association between audit-firm tenure and accounting conservatism. Accounting and Finance Research, 4 (1), 112-128.

Datar, S., Feltham, G., \& Hughes, J. (1991). The role of audits and audit quality in valuing new issues. Journal of Accounting and Economics, 14(1), 3-49.

Davidson, R. A., \& Neu, D. (1993). A note on the association between audit firm size and audit quality. Contemporary Accounting Reserach, 9(2), 479-488.

Davis, L. R., Soo, B., \& Trompeter, G. (2009). Auditor tenure and the ability to meet or beat earnings forecasts. Contemporary Accounting Research, 26(2), 517-548.

DeAngelo, L. E. (1981a). Auditor independence, low balling and disclosure regulation. Journal of Accounting and Economics(3), 113-127.

DeAngelo, L. E. (1981b). Auditor size and audit quality. Journal of Accounting and Economics(3), 183-199.

Dechow, P. M., Sloan, R. G., \& Sweeney, A. P. (1995). Detecting earnings management. The Accounting Review, 70(2), 193-225.

DeFond, M. L., \& Park, C. W. (2001). The reversal of abnormal accruals and the market 
valuation of earnings surprises. The Accounting Review, 76 (3), 375-404.

DeFond, M. L., \& Subramanyam, K. (1998). Auditor changes and discretionary accruals. Journal of Accounting and Economics, 25(1), 35 - 67.

Dopuch, N., King, R., \& Schwartz, R. (2001, junho). An experimental investigation of retention and rotation requirements. Journal of Accounting Research, 39(1), 93-117.

Doty, J. R. (2014). Statement at the sec open meeting on the pcaob 2014 budget, speech held on the pcaob 2014 budget. Washington D. C..

Dye, R. A. (1993). Auditing standards, legal liability, and auditor wealth. Journal of Political Economy, $101(5), 887-914$.

Edelson, R., \& Whisenant, S. (2012). A study of companies with abnormally favorable patterns of stock option grant dates. The University of Houston, Working Paper.

Eisenhardt, K. M. (1989). Agency theory: an assessment and review. Academy of Management Review, 15(1), 57-74.

Elitzur, R., \& Falk, H. (1996). Planned audit quality. Journal of Accounting Research, 15, 247-269.

European Commission. (2010). Audit policy: lessons from the crisis (Green Paper European Commission). Brussels.

Ewelt-Knauer, C., Gold, A., \& Pott, C. (2012). What do we know about mandatory audit firm rotation? ICAS.

Firth, M., Rui, O. M., \& Wu, X. (2012). How Do Various Forms of Auditor Rotation Affect Audit Quality? Evidence from China. The International Journal of Accounting, 47 , 109-138.

Formigoni, H., Antunes, M. T. P., Leite, R. S., \& Paulo, E. (2008). A contribuição do rodízio de auditoria para a independência e qualidade dos serviços prestados: um estudo exploratório baseado na percepção de gestores de companhias abertas brasileiras. Contabilidade Vista \& Revista, 19(3), 149-167.

Francis, J. R. (1984). The effect of audit firm size on audit prices: A study of the australian market. Journal of Accounting and Economics, 6(2), 133 - 151.

Francis, J. R., \& Ke, B. (2006). Disclosure of fees paid to auditors and the market valuation of earnings surprises. Review of Accounting Studies, 11 (4), 495-523.

Francis, J. R., Richard, C., \& Vanstraelen, A. (2009). Assessing france's joint audit requirement: Are two heads better than one? AUDITING: A Journal of Practice \&6 Theory, 28(2), 35-63.

Francis, J. R., \& Wang, D. (2008). The joint effect of investor protection and big 4 audits on earnings quality around the world. Contemporary Accounting Research, 25(1), 157-191.

Francis, J. R., \& Yu, M. D. (2009). Big 4 office size and audit quality. The Accounting Review, $84(5), 1521-1552$.

Franco, N. M. B. (2007). Cálculo numérico. Pearson Universitários. 
Frankel, M., R., Johnson, M., \& Nelson, K. (2002). The relation between auditors' fees for nonaudit services and earnings management. The Accounting Review 7r (Supplement), 71-105.

Garcia-Blandon, J., \& Argiles, J. M. (2015). Audit firm tenure and independence: A comprehensive investigation of audit qualifications in Spain. Journal of International Accounting, Auditing and Taxation, 24, 82-93.

Geiger, M., \& Raghunandan, K. (2002, março). Auditor tenure and audit reporting failures. Auditing: A journal of Practice e Theory, 21(1), 67-78.

Ghosh, A., \& Moon, D. (2005). Auditor tenure and perceptions of audit quality. The Accounting Review, 80(2), 585-612.

Gietzman, M. B., \& Sen, P. (2002). Improving auditor independence through selected mandatory rotation. International Journal of Auditing, 6, 183-210.

Gold, A., Lindscheid, F., Pott, C., \& Watrin, C. (2012). The effect of engagement partner and review partner tenure and rotation on audit quality: Evidence from Germany. Research in Accounting Regulation, Working Paper.

Gorga, r. C. R. (2005). Direito societário brasileiro e desenvolvimento do mercado de capitais: uma perspectiva de 'direito e economia' (Doutorado). Programa de PósGraduação em Direito Comercial da Faculdade de Direito da Universidade de São Paulo, São Paulo.

Gujarati, D., \& Porter, D. (2011). Econometria básica - 5.ed.: McGraw Hill Brasil.

Gul, F. A., Fung, S. Y. K., \& Jaggi, B. (2009). Earnings quality: some evidence of the role of auditor tenure and auditor's industry expertise. Journal of Accounting and Economics, 47, 265-287.

Harris, K. (2012). Mandatory audit rotation: an international investigation (Doutorado). Academic Faculty of the C. T. Bauer College of Business University of Huston, Huston.

Harris, K., \& Whisenant, S. (2012). Mandatory audit rotation: an international investigation. Disponível em http://pcaobus.org

Healy, P. (1985). The effect of bonus schemes on accounting decisions. Journal of Accounting and Economics, 7(1-3), 85-107.

Hertig, G., Kraakman, R., \& Rock, E. B. (2004). Issuers and investor protection. In R. Kraakman et al. (Eds.), The anatomy of corporate law: a comparative and functional approach. Oxford: Oxford University Press.

Hohenfels, D. (2016). Auditor tenure and perceived earnings quality. International Journal of Auditing, 20(3), 224-238.

Holthausen, R., Larcker, D., \& Sloan, R. (1995). Annual bonus schemes and the manipulation of earnings. Journal of Accounting and Economics, 19(1), 29-74.

Hoyle, J. (1978). Mandatory rotation: the arguments and an alternative. The Journal of Accountancy, 69-78. 
Hunt, I. (1997, setembro). Auditor independence and related issues (Relatório Técnico).

Hussainey, K. (2009). The impact of audit quality on earnings predictability. Managerial Auditing Journal, 24 (4), 340-351.

Hussey, R., \& Lan, G. (2001, julho). An examination of auditor independence issues from the prospective of u.k. finance director. Journal of Business Ethics, 32(2), 169-178.

Imam, S., Ahmed, Z. U., \& Khan, S. H. (2001). Association of audit delay and audit firms ̌ international links: evidence from bangladesh. Managerial Auditing Journal, 16(3), 129-134.

International Ethics Standards Board for Accountants (IESBA). (2014). Code of ethics for professional accountants (Code of Ethics for Professional Accountants).

Jackson, A. B., Moldrich, M., \& Roebuck, P. (2008). Mandatory audit firm rotation and audit quality. Managerial Auditing Journal, 23(5). Disponível em http:// ssrn. com/abstract $=1000076$

Jensen, M. C., \& Meckling, W. H. (1976). Theory of the firm: Managerial behavior, agency costs and ownership structure. Journal of Financial Economics, 3(4), 305-360.

Johnson, L. E. (1987). Further evidence on the determinants of local government audit delay. Journal of Public Budgeting, 10(3), 375-397.

Johnson, V., Khurana, I., \& Reynolds, J. (2002, Winter). Audit-firm tenure and the quality of financial reports. Contemporary Accounting Research, 19(4), 637-660.

Johnson, W. B., \& Lys, T. (1990). The market for audit services: Evidence from voluntary auditor changes. Journal of Accounting and Economics, 12(1-3), 281-308.

Jones, J. J. (1991). Earnings management during import relief investigations. Journal of Accounting Research, 29(2), 193-228.

Junaidi, Apriyanto, H. P., Nurdiono, \& Suwardi, E. (2014). The effect of audit firm tenure in artificial rotation on audit quality. Journal of Economics, Business and Accountancy Ventura, 17(3), 439-448.

Kang, S.-H., \& Sivaramakrishnan, K. (1995). Issues in testing earnings management and an instrumental variable approach. Journal of Accounting Research, 33(2), 353-367.

Knapp, M. C. (1991). Factors that audit commitees use as surrogates for audit quality. A Journal of Practice 85 Theory, 10(1), 35-52.

Krishnam, G. V. (2003). Does big 6 audit industry expertize constrain earnings management? Accounting Horizons, 1-16.

Kwon, S. Y., Lim, Y., \& Simnett, R. (2014). The effect of mandatory audit firm rotation on audit quality and audit fees: Empirical evidence from the korean audit market. AUDITING: A Journal of Practice \& Theory, 33(4), 167-196.

Lang, M., Raedy, J. S., \& Wilson, W. (2006). Earnings management and cross listing: Are reconciled earnings comparable to us earnings? Journal of Accounting and Economics, 42(1), 255 - 283.

Lang, M., Raedy, J. S., \& Yetman, M. H. (2003). How representative are firms that 
are cross-listed in the united states? an analysis of accounting quality. Journal of Accounting Research, 41(2), 363-386.

Leal, R. (2004, 01). Governance practices and corporate value: A recent literature survey. , 39, 327-337.

Lee, T., \& Stone, M. (1995). Competence and independence: the uncongenial twins of auditing? Journal of Business Finance and Accounting, 1169-1177.

Lennox, C. (1998). Bankruptcy, auditor switching and audit failure. evidence from the uk 1987-1994. , Working Paper.

Lennox, C., Wu, X., \& Zhang, T. (2014). Does mandatory rotation of audit partners improve audit quality? The Accounting Review, 89(5), 1775-1803.

Lennox, C., Wu, X., \& Zhang, T. (2016). The effect of audit adjustments on earnings quality: Evidence from china. Journal of Accounting and Economics, 61(2), 545 562.

Leventis, S., \& Caramanis, C. (2005). Determinants of audit time as a proxy of audit quality. Managerial Auditing Journal, 20(5), 460-478.

Lie, E. (2005). On the timing of ceo stock option awards. Management Science, 51, 802-812.

Lima, R. E., Araújo, M. B. V. D., \& Amaral, H. F. (2008). Conflitos de agência: um estudo comparativo dos aspectos inerentes a empresas tradicionais e cooperativas de crédito. In $V$ encontro de pesquisadores latino-americanos de cooperativismo (pp. 148-157). Ribeirão Preto.

Lopes, A. B., \& Martins, E. (2005). Teoria da contabilidade: Uma nova abordagem. São Paulo: Atlas.

Lu, T., \& Sivaramakrishnan, K. (2009). Mandatory audit firm rotation: Fresh look versus poor knowledge. Journal of Accounting and Public Policy, 28, 71-91.

Luccas, R. G. (2015). Desvendando a opinião da auditoria independente: o resultado da auditoria (Mestrado). Faculdade de Economia, Administração e Contabilidade FEA/USP, São Paulo.

Mangold, N. (1984). The effect of auditor changes on earnings, opinions and stock prices (Doutorado). University of California at Berkeley.

Mansi, S., Maxwell, W., \& Miller, D. (2004). Does auditor quality and tenure matter to investors? evidence from the bond market. Journal of Accounting Research, 42(4), 755-793.

Martinez, A. L., \& Reis, G. M. R. (2010, Set-Dez). Rodízio das firmas de auditoria e o gerenciamento de resultados no brasil. Revista de Contabilidade e Organizações FEA-RP/USP, 4 (10), 48-64.

Martins, G. d. A., \& Theóphilo, C. R. (2007). Metodologia da investigação científica para ciências sociais aplicadas. São Paulo: Atlas.

Mautz, R., \& Sharaf, H. (1961). The philosophy of auditing. American Accounting Associ- 
ation. Disponível em http://books.google.com.br/books?id=z-MgAMCp8wQC

McLaren, N. L. (1958). Rotation of auditors. The Journal of Accountancy, 106, 41-44.

Myers, J., Myers, L., \& Omer, C. (2003, julho). Exploring the term of the auditor-client relationship nd the quality of earnings: A case for mandatory auditor rotation? The Accounting Review, 78(3), 779-799.

Nagy, A. (2005). Mandatory audit firm turnover, financial reporting quality, and client bargaining power: the case of arthur andersen. Accounting Horizons, 19(2), 51-68.

O'Leary, C. (1996, abril). Compulsory rotation of auidit firms for public companies? Accountancy Ireland.

Oliveira, A. Q. d. (2005). O rodízio de fimas de auditoria e seus impactos nas demonstrações contábeis (Mestrado). Pontifícia Universidade Católica de São Paulo - PUC-SP, São Paulo.

Oliveira, A. Q. d., \& Santos, N. M. B. F. d. (2007, Set-Dez). Rodízio de firmas de auditoria: a experiência brasileira e as conclusões do mercado. Revista de Contabilidade e Finanças, 18(45), 91-100.

Pagano, M., Röell, A. A., \& Zechner, J. (2002). The geography of equity listing: Why do companies list abroad? The Journal of Finance, 57(6), 2651-2694.

PCAOB. (2011). Concept release on auditor independence and audit firm rotation (pcaob release no. 2011-009, pcaob rulemaking docket matter 37) (Relatório Técnico). Disponível em http://ec.europa.eu/internal_market/auditing/docs/reform/ regulation_en.pdf

Pierre, K. S., \& Anderson, J. (1984, abril). An analysis of the factors associated with lawsuits against public accountants. The Accounting Review, 59(2), 242-264.

Postma, E. (2016). The effects of audit firm rotation on audit quality: does audit firm rotation improve audit quality? (Mestrado). Universiteit Twente, Netherlands.

Proposal for a regulation of the european parliament and of the council on specific requirements regarding statutory audits of public-interest entities. (2011). Disponível em http://ec.europa.eu/internal_market/auditing/docs/reform/ regulation_en.pdf

Regulation (EU) No 537/2014 of the European Parliament and of the Council. (2014). Recuperado em 30 abril 2015, de http://eur-lex.europa. eu/legal-content/EN/ TXT/?uri=CELEX : 32014R0537

Reid, L. C., \& Carcello, J. V. (2017). Investor reaction to the prospect of mandatory audit firm rotation. The Accounting Review, 92(1), 183-211.

Ross, S. (1973). The economic theory of agency: the principal's problem. American Economic Review, 20(2), 22-32.

Ruiz-Barbadillo, E., Gómez-Aguilar, N., \& Carrera, N. (2009). Does mandatory audit firm rotation enhance auditor independence? evidence from spain. AUDITING: A Journal of Practice \&6 Theory, 28(1), 113-135. Disponível em https://doi.org/ 
10.2308/aud.2009.28.1.113 doi: 10.2308/aud.2009.28.1.113

Ruiz-Barbadillo, E., \& Gomez-Aguilar, N. (2002). Does auditor tenure improve audit quality? mandatory auditor rotation versus long term auditing. an empirical analysis. , Working Paper.

Santos, F. P. (2008). A relação entre o parecer de auditoria e a troca de auditores: uma investigação nas instituições financeiras (Mestrado). FGV, Rio de Janeiro.

SDA Bocconi School of Management. (2002). The impact of mandatory audit rotation on audit quality and on audit pricing: the case of italy (Academic research, Unpublished). SDA Bocconi School of Management.

Shleifer, A., \& Vishny, R. W. (1997, August). A survey of corporate governance. Journal of Finance, 52(2), 737-783.

Silva, J. O. d., \& Bezerra, F. A. (2010). Análise do gerenciamento de resultados e o rodízio de firmas de auditoria nas empresas de capital aberto. Revista Brasileira de Gestão de Negócios, 12(36), 304-321.

Silvestre, A. O. (2016). Rodízio de auditoria e qualidade dos lucros: uma análise a partir dos accruals residuais (Mestrado). Universidade do Vale do Rio dos Sinos, São Leopoldo.

Silvestre, A. O., Costa, C. M., \& Kronbauer, C. A. (2017, Junho). RodÍzio de auditoria e a qualidade dos lucros: Uma anÁlise a partir dos accruals residuais. In Anais do xi congresso anpcont. Associação Nacional de Programas de Pós Graduação em Ciências Contábeis. Disponível em http://congressos.anpcont.org.br/xi/ anais/files/2017-05/cue764.pdf

Summer, M. (1998). Does mandatory rotation enhance auditor independence. Zeitschrift für Wirtschafts-u. Sozialwissenschaften, 118, 327-359.

Tarca, A. (2004). International convergence of accounting practices: Choosing between ias and us gaap. Journal of International Financial Management 6 Accounting, 15(1), 60-91.

Tepalagul, N., \& Lin, L. (2014). Auditor Independence and Audit Quality: A Literature Review. Journal of Accounting, Auditing and Financer, 30 (1), 101-121.

Tirole, J. (2006). The theory of corporate finance. New Jersey: Princeton University Press.

Titman, S., \& Trueman, B. (1986). Information quality and the valuation of new issues. Journal of Accounting and Economics, 8(2), 159-172.

U.S. Government Accountability Office - GAO. (2003). Public accounting firms: Required study on the potential effects of mandatory audit firm rotation (Relatório Técnico). Washington D.C..

Vanstraelen, A. (2000, setembro). Impact of renewable long-term audit mandates on audit quality. The European Accounting Review, 9(3), 419-443.

Walker, P., Lewis, B., \& Casterella, J. (2001, abril). Mandatory auditor rotation: Arguments 
and current evidence. Accounting Enquiries, 10(2).

Watkins, A. L., Hillison, W., \& Morecroft, S. E. (2004). Audit quality - a synthesis of theory and empirical evidence. Journal of Accounting Literature, 23, 153-193.

Watts, R., \& Zimmerman, J. L. (1983, outubro). Agency problems, auditing and the theory of the firm: some evidence. Journal of Law anda Economics, 26, 613-634.

Watts, R., \& Zimmerman, J. L. (1986). Positive theory of accounting. New Jersey: Prentice Hall.

Wu Xi, C., \& Zhang, T. (2013). Change for Change's Sake ? Does Mandatory Partner Rotation Improve Audit Quality ? Shanghai: ACCOUNTING, MIT ASIA CONFERENCE IN. Disponível em HTTP://mitsloan.mit.edu/EVENTS/ ASIA-CONFERENCE-IN-ACCOUNTING/OVERVIEW . PHP

Wu-Chun, C., Hung-Chao, Y., \& Shih-Tsung, C. (2002). Mandatory rotation and auditor independence an analysis of auditor's reputation effects. Apresentado no AAA annual meeting, 2002, Working Paper.

Yelle, L. E. (1979). The learning curve: historical review and comprehensive survey. Decision Sciences(10), 302-328.

Yermack, D. (1997). Good timing: Ceo stock option awards and company news announcements. Journal of Finance, 52(2), 449-476. 

Apêndices 

APÊNDICE A - Resumo da literatura 
Tabela 11 - Quadro resumo da bibliografia.

\begin{tabular}{|c|c|c|c|c|c|}
\hline Autor/Título & Detalhes do trabalho & $\begin{array}{c}\text { Posição sobre o } \\
\text { RMF }\end{array}$ & Método de análise & $\begin{array}{c}\text { Países } \\
\text { estudados }\end{array}$ & Principais Resultados \\
\hline \multicolumn{6}{|c|}{ (i) Rodízio mandatório de firmas e independência da auditoria } \\
\hline $\begin{array}{l}\text { Bamber e Iyer (2007) } \\
\text { "Auditors's identification } \\
\text { with their clients and } \\
\text { its effect, on auditors's } \\
\text { objectivity" }\end{array}$ & $\begin{array}{l}\text { Publicado } \\
\text { Auditing: A Journal of Prac- } \\
\text { tice \& Theory }\end{array}$ & Indefinido & Questionário & & $\begin{array}{l}\text { Auditores de fato se identificam com os seus } \\
\text { clientes e os auditores que se identificam mais } \\
\text { com um cliente são mais propensos a concor- } \\
\text { dar com a posição preferida pelo cliente. Por } \\
\text { outro lado, os auditores mais experientes e au- } \\
\text { ditores que apresentam níveis mais elevados } \\
\text { de identificação profissional são menos pro- } \\
\text { pensos a concordar com a posição do cliente. }\end{array}$ \\
\hline $\begin{array}{l}\text { Bauer (2013) } \\
\text { "The Effects of Client Iden- } \\
\text { tity Strength and Professio- } \\
\text { nal Identity Salience on Au- } \\
\text { ditor Judments" }\end{array}$ & $\begin{array}{l}\text { Publicado } \\
\text { Auditing: A Journal of Prac- } \\
\text { tice \& Theory }\end{array}$ & Contra & Experimento & & $\begin{array}{l}\text { Auditores com uma identidade-cliente mais } \\
\text { forte concordam mais com as preferências dos } \\
\text { clientes, mas esse efeito é eliminado quando a } \\
\text { consciência dessa identidade é destacada. }\end{array}$ \\
\hline $\begin{array}{l}\text { Daniels e Booker (2011) } \\
\text { "The effects of audit firm ro- } \\
\text { tation on perceived auditor } \\
\text { independence and audit qua- } \\
\text { lity" }\end{array}$ & $\begin{array}{l}\text { Publicado } \\
\text { Research in Accounting Re- } \\
\text { gulation }\end{array}$ & Mista & $\begin{array}{l}\text { Experimento } \\
\text { (com bancos de emprésti- } \\
\text { mos oficiais) }\end{array}$ & & $\begin{array}{l}\text { Percepções sobre a independência do auditor } \\
\text { são melhoradas com o rodízio mandatório de } \\
\text { firmas de auditoria. Percepções sobre a quali- } \\
\text { dade de auditoria não são afetadas pelo rodí- } \\
\text { zio mandatório de firmas de auditoria. }\end{array}$ \\
\hline $\begin{array}{l}\text { Dopuch et al. }(2001)^{\star} \\
\text { "An experimental investiga- } \\
\text { tion of retention and rota- } \\
\text { tion requirements" }\end{array}$ & $\begin{array}{l}\text { Publicado } \\
\text { Journal of Accounting Rese- } \\
\text { arch }\end{array}$ & A favor & $\begin{array}{l}\text { Experimento } \\
\text { (interação multi-período } \\
\text { entre gerentes que inves- } \\
\text { tem em um ativo de risco } \\
\text { e um auditor que emite } \\
\text { um relatório sobre este } \\
\text { ativo) }\end{array}$ & & $\begin{array}{l}\text { A probabilidade de que os auditores forneçam } \\
\text { relatórios viesados em favor da gestão diminui } \\
\text { com a exigência de rotação. }\end{array}$ \\
\hline $\begin{array}{l}\text { Formigoni et al. }(2008)^{\star} \\
\text { "A contribuição do rodízio } \\
\text { de auditoria para a indepen- } \\
\text { dência e qualidade dos ser- } \\
\text { viços prestados: um estudo } \\
\text { exploratório baseado na per- } \\
\text { cepção de gestores de compa- } \\
\text { nhias abertas brasileiras" }\end{array}$ & $\begin{array}{l}\text { Publicado } \\
\text { Contabilidade Vista \& Re- } \\
\text { vista }\end{array}$ & Contra & Questionário & Brasil & $\begin{array}{l}\text { A introdução do rodízio mandatório de firmas } \\
\text { e auditoria no Brasil não trouxe soluções sa- } \\
\text { tisfatórias para os conflitos de interesses que } \\
\text { possam vir a surgir do relacionamento entre } \\
\text { cliente e contratante. }\end{array}$ \\
\hline
\end{tabular}


Tabela 11 - (continuação)

\begin{tabular}{|c|c|c|c|c|c|}
\hline Autor/Título & Detalhes do trabalho & $\begin{array}{l}\text { Posição sobre o } \\
\text { RMF }\end{array}$ & Método de análise & $\begin{array}{c}\text { Países } \\
\text { estudados }\end{array}$ & Principais Resultados \\
\hline $\begin{array}{l}\text { Garcia-Blandon e Argiles } \\
\text { (2015) } \\
\text { "Audit firm tenure and inde- } \\
\text { pendence: A comprehensive } \\
\text { investigation of audit quali- } \\
\text { fications in Spain" }\end{array}$ & $\begin{array}{l}\text { Publicado } \\
\text { Journal of International Ac- } \\
\text { counting, Auditing and Ta- } \\
\text { xation }\end{array}$ & $\begin{array}{l}\text { A favor, mas com } \\
\text { ressalvas em rela- } \\
\text { ção ao custo do re- } \\
\text { gime. }\end{array}$ & $\begin{array}{l}\text { Archival } \\
\text { (Regressão entre o tipo de } \\
\text { opinião emitida pelo au- } \\
\text { ditor, período de relacio- } \\
\text { namento auditor-auditado } \\
\text { e outras variáveis de con- } \\
\text { trole). }\end{array}$ & Espanha & $\begin{array}{l}\text { Os auditores parecem dispostos a sacrificar } \\
\text { sua independência em longos períodos de rela- } \\
\text { cionamento, mas apenas em casos de opinião } \\
\text { modificada decorrente de problemas de conti- } \\
\text { nuidade. }\end{array}$ \\
\hline $\begin{array}{l}\text { Gietzman e Sen }(2002)^{\star} \\
\text { "Improving auditor indepen- } \\
\text { dence through selected man- } \\
\text { datory rotation" }\end{array}$ & $\begin{array}{l}\text { Publicado } \\
\text { International Journal of au- } \\
\text { diting }\end{array}$ & A favor & $\begin{array}{l}\text { Analítico } \\
\text { (Jogo de auditoria) }\end{array}$ & & $\begin{array}{l}\text { Se o mercado de auditoria é suficientemente } \\
\text { restrito (poucos grandes clientes) o rodízio } \\
\text { mandatório aumenta a independência e reduz } \\
\text { o risco de conluio. }\end{array}$ \\
\hline $\begin{array}{l}\text { Hussey e Lan }(2001)^{\star} \\
\text { "An examination of auditor } \\
\text { independence issues from } \\
\text { the prospective of U.K. Fi- } \\
\text { nance Director" }\end{array}$ & $\begin{array}{l}\text { Publicado } \\
\text { Journal of Business Ethics }\end{array}$ & Contra & $\begin{array}{l}\text { Questionário e regressão } \\
\text { múltipla (Diretores finan- } \\
\text { ceiros) }\end{array}$ & Reino Unido & $\begin{array}{l}\text { A independência percebida dos auditores } \\
\text { pode ser reforçada pelo rodízio mandatório. }\end{array}$ \\
\hline $\begin{array}{l}\text { Lu e Sivaramakrishnan } \\
(2009) \\
\text { "Mandatory audit firm } \\
\text { rotation: Fresh look versus } \\
\text { poor knowledge" }\end{array}$ & $\begin{array}{l}\text { Publicado Journal of Ac- } \\
\text { counting and Public Policy }\end{array}$ & $\begin{array}{l}\text { A favor e contra, } \\
\text { dependendo da si- } \\
\text { tuação. }\end{array}$ & Modelo analítico & & $\begin{array}{l}\text { Ao investigar a influência do rodízio mandató- } \\
\text { rio (RM) no mercado de capitais, quando não } \\
\text { há problemas de opinion shopping, o RM pre- } \\
\text { judica a eficiência de investimentos. Mas, na } \\
\text { ausência de incentivos a opinion shopping, o } \\
\text { RM melhora ou prejudica a eficiência do inves- } \\
\text { timento dependendo da perspectiva do cliente } \\
\text { e do viés do auditor. }\end{array}$ \\
\hline $\begin{array}{l}\text { O'Leary }(1996)^{\star} \\
\text { "Compulsory Rotation of } \\
\text { Audit Firms for Public Com- } \\
\text { panies?" }\end{array}$ & $\begin{array}{l}\text { Publicado } \\
\text { Accountancy Ireland }\end{array}$ & Contra & Questionário & Austrália & $\begin{array}{l}\text { Os benefícios do rodízio mandatório são com- } \\
\text { pensados pelos custos associados, mesmo se a } \\
\text { percepção da independência for melhorada. }\end{array}$ \\
\hline $\begin{array}{l}\text { Oliveira }(2005)^{\star} \\
\text { "O rodízio de fimas de audi- } \\
\text { toria e seus impactos nas de- } \\
\text { monstrações contábeis" }\end{array}$ & $\begin{array}{l}\text { Publicado } \\
\text { Dissertação Pontifícia Uni- } \\
\text { versidade Católica de São } \\
\text { Paulo }\end{array}$ & Contra & Questionário & Brasil & $\begin{array}{l}\text { O rodízio de firmas de auditoria não tem ca- } \\
\text { pacidade de assegurar a independência do au- } \\
\text { ditor no seu trabalho e não diminui os riscos } \\
\text { de erros contábeis e de fraudes na elaboração } \\
\text { das demonstrações contábeis no Brasil. }\end{array}$ \\
\hline $\begin{array}{l}\text { Ruiz-Barbadillo e Gomez- } \\
\text { Aguilar }(2002)^{\star} \\
\text { "Does Auditor Tenure Im- } \\
\text { prove Audit Quality? Man- } \\
\text { datory auditor Rotation Ver- } \\
\text { sus Long Term Auditing: An } \\
\text { empirical analysis" }\end{array}$ & $\begin{array}{l}\text { Não publicado } \\
\text { Working paper }\end{array}$ & Contra & $\begin{array}{l}\text { Archival } \\
\text { (regressão logísitca) }\end{array}$ & $\begin{array}{l}\text { Espanha } \\
\text { (companhias } \\
\text { listadas) }\end{array}$ & $\begin{array}{l}\text { O auditor mostra mais dependência no pri- } \\
\text { meiro ano do contrato porque querem recupe- } \\
\text { rar o investimento inicial feito a fim de enten- } \\
\text { der o negócio do cliente }\end{array}$ \\
\hline
\end{tabular}


Tabela 11 - (continuação)

\begin{tabular}{|c|c|c|c|c|c|}
\hline Autor/Título & Detalhes do trabalho & $\begin{array}{c}\text { Posição sobre o } \\
\text { RMF }\end{array}$ & Método de análise & $\begin{array}{c}\text { Países } \\
\text { estudados }\end{array}$ & Principais Resultados \\
\hline $\begin{array}{l}\text { SDA Bocconi School of Ma- } \\
\text { nagement }(2002)^{\star} \\
\text { "The impact of mandatory } \\
\text { audit rotation on audit qua- } \\
\text { lity and on audit pricing: the } \\
\text { case of Italy" }\end{array}$ & Não publicado & Contra & $\begin{array}{l}\text { Archival } \\
\text { (análise quantitativa) } \\
\text { Questionários } \\
\text { (CFOs de companhias lis- } \\
\text { tadas, CFOs "Sindaci" e } \\
\text { auditores internos } \\
\end{array}$ & Itália & $\begin{array}{l}\text { O rodízio mandatório produz efeitos positivos } \\
\text { sobre a independência percebida, mas gera } \\
\text { custos sociais excessivamente elevados }\end{array}$ \\
\hline $\begin{array}{l}\text { Summer }(1998)^{\star} \\
\text { "Does mandatory } \\
\text { enhance auditor } \\
\text { dence" }\end{array}$ & $\begin{array}{l}\text { Publicado } \\
\text { Zeitschrift für Wirtschafts- } \\
\text { u. Sozialwissenschafte }\end{array}$ & Contra & $\begin{array}{l}\text { Analítico } \\
\text { (Jogo entre mutuários, au- } \\
\text { ditores e mercado de capi- } \\
\text { tal) }\end{array}$ & & $\begin{array}{l}\text { Os auditores são menos independentes em } \\
\text { compromissos de curto do que de longo prazo, } \\
\text { então, uma regra de rodízio pode ter efeitos } \\
\text { adversos sobre a independência dos auditores }\end{array}$ \\
\hline $\begin{array}{l}\text { Wu-Chun et al. }(2002)^{\star} \\
\text { "Mandatory rotation and au- } \\
\text { ditor independence an analy- } \\
\text { sis of auditor's reputation ef- } \\
\text { fects" }\end{array}$ & $\begin{array}{l}\text { Não publicado } \\
\text { Working paper }\end{array}$ & Contra & $\begin{array}{l}\text { Analítico } \\
\text { (modelo de dois períodos) }\end{array}$ & & $\begin{array}{l}\text { O rodízio mandatório pode ter efeitos nega- } \\
\text { tivos sobre a independência do auditor se o } \\
\text { prêmio nos honorários de auditoria, o lucro } \\
\text { normal de auditoria e a a probabilidade de } \\
\text { situações ruins são ignorados }\end{array}$ \\
\hline \multicolumn{6}{|c|}{ (ii) rodízio mandatório de firmas e qualidade da auditoria } \\
\hline $\begin{array}{l}\text { Arruñada e Paz-Ares } \\
(1997)^{\star} \\
\text { "Mandatory rotation of com- } \\
\text { pany auditors: A critical } \\
\text { examination" }\end{array}$ & $\begin{array}{l}\text { Publicado } \\
\text { International Review of Law } \\
\text { and Economics }\end{array}$ & Contra & Pesquisa analítica & & $\begin{array}{l}\text { A regra de rodízio não modifica o custo de } \\
\text { transação de conluio e reduz tanto a proba- } \\
\text { bilidade de detectar reportes não feitos por } \\
\text { auditores e a quantidade sanções associadas } \\
\text { a tal detecção }\end{array}$ \\
\hline $\begin{array}{l}\text { Azevedo e Costa (2012) } \\
\text { "Efeito da troca da firma de } \\
\text { auditoria no gerenciamento } \\
\text { de resultados das compa- } \\
\text { nhias abertas brasileiras" }\end{array}$ & $\begin{array}{l}\text { Publicado } \\
\text { Revista de Administração } \\
\text { Mackenzie }\end{array}$ & & & & $\begin{array}{l}\text { Através de dois modelos e cinco métricas de } \\
\text { gerenciamento de resultados, não foi possível } \\
\text { afirmar que a troca de auditor leva a redução } \\
\text { no nível de gerenciamento de resultados. }\end{array}$ \\
\hline $\begin{array}{l}\text { "Bates et al. }(1982)^{\star} \\
\text { "Auditor-client affiliation: } \\
\text { the impact on materiality (a } \\
\text { study of the effect of auditor } \\
\text { rotation on materiality } \\
\text { judgments)" }\end{array}$ & $\begin{array}{l}\text { Publicado } \\
\text { Journal of Accountancy }\end{array}$ & Contra & Experimento & EUA & $\begin{array}{l}\text { A materialidade do julgamento do auditor é } \\
\text { afetada pelas associações de longa duração en- } \\
\text { tre cliente e auditor (o rodízio obrigatório é } \\
\text { muito caro como uma solução. É suficiente a } \\
\text { rotação do sócio) }\end{array}$ \\
\hline $\begin{array}{l}\text { Bedard e Johnstone (2010) } \\
\text { "Audit partner tenure and } \\
\text { audit planning and pricing" }\end{array}$ & $\begin{array}{l}\text { Publicado } \\
\text { Auditing: A Journal of Prac- } \\
\text { tice \& Theory }\end{array}$ & Contra & $\begin{array}{l}\text { Archival } \\
\text { (usando dados privados de } \\
\text { uma grande firma de audi- } \\
\text { toria dos EUA) }\end{array}$ & EUA & $\begin{array}{l}\text { Os esforços de planejamento aumentam após } \\
\text { o rodízio de sócios, indicando que novos sócios } \\
\text { investem esforço adicional em seus primeiros } \\
\text { anos de relacionamento com o cliente para ad- } \\
\text { quirir conhecimento específico sobre ele. }\end{array}$ \\
\hline
\end{tabular}


Tabela 11 - (continuação)

\begin{tabular}{|c|c|c|c|c|c|}
\hline Autor/Título & Detalhes do trabalho & $\begin{array}{c}\text { Posição sobre o } \\
\text { RMF }\end{array}$ & Método de análise & $\begin{array}{c}\text { Países } \\
\text { estudados }\end{array}$ & Principais Resultados \\
\hline $\begin{array}{l}\text { Brooks et al. (2013) } \\
\text { "Audit Firm Tenure and Au- } \\
\text { dit Quality: Evidence from } \\
\text { U.S. Firms" }\end{array}$ & $\begin{array}{l}\text { Não publicado } \\
\text { Working Paper }\end{array}$ & Contra & Archival & $\begin{array}{l}\text { Estados Uni- } \\
\text { dos }\end{array}$ & $\begin{array}{l}\text { Ao fazer uma modelagem quadrática da qua- } \\
\text { lidade da auditoria em função da tenure } \\
\text { percebeu-se que o máximo da qualidade da au- } \\
\text { ditoria ocorre por volta de } 12 \text { anos, de forma } \\
\text { que os autores se posicionam contra o rodízio } \\
\text { em } 10 \text { anos conforme proposto pelo PCAOB. }\end{array}$ \\
\hline $\begin{array}{l}\text { Carcello e Nagy }(2004)^{\star} \\
\text { "Audit Firm Tenure and } \\
\text { Fraudolent Financial Repor- } \\
\text { ting" }\end{array}$ & $\begin{array}{l}\text { Publicado } \\
\text { Auditing: A Journal of Prac- } \\
\text { tice \& Theory }\end{array}$ & Contra & $\begin{array}{l}\text { Archival } \\
\text { (modelo de regressão logís- } \\
\text { tica) }\end{array}$ & EUA & $\begin{array}{l}\text { Reportes financeiros fraudulentos são mais } \\
\text { prováveis de ocorrer nos anos iniciais de re- } \\
\text { lacionamento }\end{array}$ \\
\hline $\begin{array}{l}\text { Carey e Simnett (2006) } \\
\text { "Audit partner tenure and } \\
\text { audit quality" }\end{array}$ & $\begin{array}{l}\text { Publicado } \\
\text { The Accounting Review } \\
2006\end{array}$ & Contra & $\begin{array}{l}\text { Archival } \\
\text { (Regressão entre longos } \\
\text { períodos de relacio- } \\
\text { namento do sócio de } \\
\text { auditoria com o cliente e } \\
\text { a qualidade da auditoria). }\end{array}$ & Austrália & $\begin{array}{l}\text { Ao utilizar três diferentes proxies para quali- } \\
\text { dade da auditoria, foi verificado para duas de- } \\
\text { las que um longo período de relacionamento } \\
\text { entre o sócio de auditoria e seu cliente leva a } \\
\text { uma deterioração da qualidade da auditoria e, } \\
\text { para a terceira, não foi encontrada evidência } \\
\text { de associação entre essas variáveis. Ainda as- } \\
\text { sim, os autores entendem que os custos desse } \\
\text { regime podem ser maiores que seus benefícios. }\end{array}$ \\
\hline $\begin{array}{l}\text { Chung }(2004)^{\star} \\
\text { "Selective Mandatory Audi- } \\
\text { tor Rotation and Audit Qua- } \\
\text { lity: an Empirical Investig- } \\
\text { tion of Auditor Designation } \\
\text { Policy in Korea" }\end{array}$ & $\begin{array}{l}\text { Não publicado } \\
\text { Working paper }\end{array}$ & A favor & $\begin{array}{l}\text { Archival } \\
\text { (modelo com cross-section } \\
\text { modificado) }\end{array}$ & $\begin{array}{l}\text { Korea } \\
\text { (companhias } \\
\text { listadas) }\end{array}$ & $\begin{array}{l}\text { A qualidade da auditoria é melhorada quando } \\
\text { a duração do relacionamento cliente-auditor é } \\
\text { truncada }\end{array}$ \\
\hline $\begin{array}{l}\text { Church e Zhang }(2006) \\
\text { "A model of mandatory au- } \\
\text { ditor rotation" }\end{array}$ & $\begin{array}{l}\text { Não publicado } \\
\text { Working paper }\end{array}$ & $\begin{array}{l}\text { A favor e contra, } \\
\text { dependendo da si- } \\
\text { tuação. }\end{array}$ & Modelo analítico & & $\begin{array}{l}\text { A independência, e portanto a qualidade, é } \\
\text { melhorada com o sistema de rodízio manda- } \\
\text { tório, mas o benefício líquido depende do pe- } \\
\text { ríodo de rotação, dos custos iniciais, dos cus- } \\
\text { tos associados aos vieses de opinião, do conhe- } \\
\text { cimento do auditor e do intervalo de tempo de } \\
\text { incentivos dos gestores. O rodízio mandatório } \\
\text { de firmas será preferível se o período de rodí- } \\
\text { zio for longo, se os custos iniciais forem altos, } \\
\text { se os custos de opiniões viesadas forem altos, } \\
\text { se o conhecimento do auditor for dramático } \\
\text { em termos de melhorar a eficiência da audi- } \\
\text { toria ao longo do tempo e se o gerente (au- } \\
\text { ditado) for or focado em benefícios de curto } \\
\text { prazo. }\end{array}$ \\
\hline
\end{tabular}


Tabela 11 - (continuação)

\begin{tabular}{|c|c|c|c|c|c|}
\hline Autor/Título & Detalhes do trabalho & $\begin{array}{c}\text { Posição sobre o } \\
\text { RMF }\end{array}$ & Método de análise & $\begin{array}{c}\text { Países } \\
\text { estudados }\end{array}$ & $\overline{\text { Principais Resultados }}$ \\
\hline $\begin{array}{l}\text { Copley e Doucet (1993) * } \\
\text { "Auditor Tenure, Fixed Fee } \\
\text { Contracts, and the Supply of } \\
\text { Substandard Single Audits" }\end{array}$ & $\begin{array}{l}\text { Publicado } \\
\text { Public Budgeting \& Finance }\end{array}$ & A favor & $\begin{array}{l}\text { Archival } \\
\text { (modelo cross-section) }\end{array}$ & EUA & $\begin{array}{l}\text { A probabilidade de receber um sub-padrão de } \\
\text { auditoria aumenta com o tempo de relaciona- } \\
\text { mento }\end{array}$ \\
\hline $\begin{array}{l}\text { Cunha et al. (2015) } \\
\text { Efeito da Troca da Firma de } \\
\text { Auditoria no Gerenciamento } \\
\text { de Resultados das Compa- } \\
\text { nhias Abertas Brasileiras }\end{array}$ & $\begin{array}{l}\text { Publicado } \\
\text { Congresso UFSC de Contro- } \\
\text { ladoria e Finanças }\end{array}$ & Contra & Archival & Brasil & $\begin{array}{l}\text { Os resultados encontrados apontam que a } \\
\text { troca da firma de auditoria não tem efeito so- } \\
\text { bre o gerenciamento de resultados das empre- } \\
\text { sas analisadas. }\end{array}$ \\
\hline $\begin{array}{l}\text { Dantas e Medeiros (2015) } \\
\text { Determinantes de Qualidade } \\
\text { da Auditoria Independente } \\
\text { em Bancos }\end{array}$ & $\begin{array}{l}\text { Publicado } \\
\text { Revista Contabilidade \& Fi- } \\
\text { nanças }\end{array}$ & A favor & $\begin{array}{l}\text { Archival } \\
\text { (regressão de qualidade } \\
\text { da auditoria contra pe- } \\
\text { ríodo de relacionamento } \\
\text { auditor-auditado) }\end{array}$ & $\begin{array}{l}\text { Brasil (insti- } \\
\text { tuições finan- } \\
\text { ceiras) }\end{array}$ & $\begin{array}{l}\text { A qualidade dos trabalhos de auditoria tem } \\
\text { relação negativa com os trabalhos do auditor } \\
\text { a partir do sexto ano de contrato. }\end{array}$ \\
\hline $\begin{array}{l}\text { Elitzur e Falk (1996) } \\
\text { "Planned Audit Quality" }\end{array}$ & $\begin{array}{l}\text { Publicado } \\
\text { Journal of Accounting and } \\
\text { Public policy }\end{array}$ & Contra & $\begin{array}{l}\text { Analítico } \\
\text { (modelo multi-períodos) }\end{array}$ & & $\begin{array}{l}\text { A qualidade de auditoria prevista é negati- } \\
\text { vamente afetada por uma política de rodízio } \\
\text { mandatório de auditor independente }\end{array}$ \\
\hline $\begin{array}{l}\text { Firth et al. (2012) } \\
\text { "How Do Various Forms of } \\
\text { Auditor Rotation Affect Au- } \\
\text { dit Quality? Evidence from } \\
\text { China." }\end{array}$ & $\begin{array}{l}\text { Publicado } \\
\text { The International Journal of } \\
\text { Accounting }\end{array}$ & Contra & $\begin{array}{l}\text { Archival } \\
\text { (regressão de qualidade } \\
\text { da auditoria contra pe- } \\
\text { ríodo de relacionamento } \\
\text { auditor-auditado) }\end{array}$ & China & $\begin{array}{l}\text { O rodízio mandatório de sócios de auditoria } \\
\text { provoca um aumento significativo da quali- } \\
\text { dade de auditoria, na presença de instituições } \\
\text { legais fracas. Evidências similares são repor- } \\
\text { tadas para o rodízio voluntário de firmas de } \\
\text { auditoria, porém, com um nível de confiança } \\
\text { muito menor. Quanto a outras formas de ro- } \\
\text { dízio (i.e., rodízio mandatório de firma de au- } \\
\text { ditoria e rodízio voluntário de sócio de audi- } \\
\text { toria), não foram encontrados efeitos na pro- } \\
\text { pensão a receber um parecer de auditoria mo- } \\
\text { dificado. }\end{array}$ \\
\hline $\begin{array}{l}\text { Geiger e Raghunandan } \\
(2002)^{\star} \\
\text { "Auditor tenure and audit } \\
\text { reporting failures" }\end{array}$ & $\begin{array}{l}\text { Publicado } \\
\text { Auditing: A journal of Prac- } \\
\text { tice \& Theory }\end{array}$ & Contra & $\begin{array}{l}\text { Archival } \\
\text { (regressão logística multi- } \\
\text { variada) }\end{array}$ & EUA & $\begin{array}{l}\text { Existem mais falhas de relatórios de audito- } \\
\text { ria nos primeiros anos do relacionamento cli- } \\
\text { ente/auditor }\end{array}$ \\
\hline $\begin{array}{l}\text { Gold et al. (2012) } \\
\text { "The effect of engagement } \\
\text { partner and review partner } \\
\text { tenure and rotation on audit } \\
\text { quality: Evidence from Ger- } \\
\text { many" }\end{array}$ & $\begin{array}{l}\text { Não publicado } \\
\text { Working paper }\end{array}$ & & & Alemanha & \\
\hline
\end{tabular}


Tabela 11 - (continuação)

\begin{tabular}{|c|c|c|c|c|c|}
\hline Autor/Título & Detalhes do trabalho & $\begin{array}{c}\text { Posição sobre o } \\
\text { RMF }\end{array}$ & Método de análise & $\begin{array}{c}\text { Países } \\
\text { estudados }\end{array}$ & Principais Resultados \\
\hline $\begin{array}{l}\text { Harris }(2012) \\
\text { "Mandatory auditor rota- } \\
\text { tion: an international inves- } \\
\text { tigation" }\end{array}$ & $\begin{array}{l}\text { Tese de doutorado } \\
\text { University of Houston }\end{array}$ & A favor. & $\begin{array}{l}\text { Archival } \\
\text { (diversos modelos) }\end{array}$ & $\begin{array}{l}\text { Brasil, Corea } \\
\text { do Sul e Itália }\end{array}$ & $\begin{array}{l}\text { Os resultados apontaram uma melhoria na in- } \\
\text { dependência após a utilização do rodízio man- } \\
\text { datório de firmas, porém revelando a neces- } \\
\text { sidade de se considerar maneiras de mitigar } \\
\text { a erosão da qualidade da auditoria, devido à } \\
\text { perda de conhecimento específico do cliente, } \\
\text { ao se proceder à troca do auditor. }\end{array}$ \\
\hline $\begin{array}{l}\text { Jackson et al. (2008) } \\
\text { "Mandatory audit firm rota- } \\
\text { tion and audit quality" }\end{array}$ & $\begin{array}{l}\text { Publicado } \\
\text { Managerial Auditing Jour- } \\
\text { nal }\end{array}$ & Contra & $\begin{array}{l}\text { Archival } \\
\text { (regressão de qualidade } \\
\text { da auditoria - utilizando } \\
\text { accruals discricionários } \\
\text { como proxy - contra pe- } \\
\text { ríodo de relacionamento } \\
\text { auditor-auditado) }\end{array}$ & Austrália & $\begin{array}{l}\text { A qualidade da auditoria aumenta à me- } \\
\text { dida que aumenta o período de relaciona- } \\
\text { mento auditor-auditado, quando se utiliza } \\
\text { como proxy a propensão a emitir uma opi- } \\
\text { nião de continuidade e não é afetada quando } \\
\text { se utiliza como proxy accruals discricionários. }\end{array}$ \\
\hline $\begin{array}{l}\text { V. Johnson et al. }(2002)^{\star} \\
\text { "Audit-firm tenure and the } \\
\text { quality of financial reports" }\end{array}$ & $\begin{array}{l}\text { Publicado } \\
\text { Contemporary Accounting } \\
\text { Research }\end{array}$ & Contra & $\begin{array}{l}\text { Archival } \\
\text { (regressão estatística de } \\
\text { amostra determinada) }\end{array}$ & EUA & $\begin{array}{l}\text { Curtos prazos relacionamento auditor-cliente } \\
\text { estão associados a um declínio na qualidade } \\
\text { dos relatótios financeiros }\end{array}$ \\
\hline $\begin{array}{l}\text { Lennox }(1998)^{\star} \\
\text { "Bankruptcy, Auditor Swit- } \\
\text { ching and audit Failure. Evi- } \\
\text { dence from the UK 1987- } \\
1994 "\end{array}$ & Não publicado & Contra & $\begin{array}{l}\text { Experimental } \\
\text { Economia }\end{array}$ & $\begin{array}{l}\text { Reino Unido } \\
\text { (companhias } \\
\text { listadas) }\end{array}$ & $\begin{array}{l}\text { Troca compulsória de auditor reduz a acurá- } \\
\text { cia do relatório de auditoria }\end{array}$ \\
\hline $\begin{array}{l}\text { Martinez e Reis (2010) } \\
\text { "Rodízio dAS firmas de Au- } \\
\text { ditoria e O GeRENCIA- } \\
\text { MENTO de Resultados no } \\
\text { Brasil" }\end{array}$ & $\begin{array}{l}\text { Publicado } \\
\text { Revista de Contabilidade e } \\
\text { Organizações }\end{array}$ & Contra & Archival & Brasil & $\begin{array}{l}\text { Não foram verificadas evidências de variação } \\
\text { na prática de gerenciamento de resultados } \\
\text { quando ocorre o rodízio }\end{array}$ \\
\hline $\begin{array}{l}\text { Myers et al. }(2003)^{\star} \\
\text { "Exploring the Term of the } \\
\text { auditor-client relationship } \\
\text { nd the quality of Earnings: } \\
\text { A case for Mandatory } \\
\text { Auditor rotation?" }\end{array}$ & $\begin{array}{l}\text { Publicado } \\
\text { The Accounting Review }\end{array}$ & Contra & $\begin{array}{l}\text { Archival } \\
\text { (análises uni e multivaria- } \\
\text { das) }\end{array}$ & EUA & $\begin{array}{l}\text { Um prazo mais longo do relacionamento } \\
\text { auditor-cliente está associado com uma me- } \\
\text { nor dispersão de accruals discricionários. }\end{array}$ \\
\hline $\begin{array}{l}\text { Nagy }(2005)^{\star} \\
\text { "Mandatory audit firm tur- } \\
\text { nover, financial reporting } \\
\text { quality, and client bargai- } \\
\text { ning power: the case of } \\
\text { Arthur Andersen" }\end{array}$ & $\begin{array}{l}\text { Publicado } \\
\text { Accounting Horizons }\end{array}$ & & $\begin{array}{l}\text { ARCHIVAL } \\
\text { (Regressão) }\end{array}$ & $\begin{array}{l}\text { EUA } \\
\text { (pequenas } \\
\text { companhias) }\end{array}$ & $\begin{array}{l}\text { Para as pequenas companhias existe relação } \\
\text { não significativa entre curto período de relaci- } \\
\text { onamento auditor-auditado e accruals discri- } \\
\text { cionários. }\end{array}$ \\
\hline
\end{tabular}


Tabela 11 - (continuação)

\begin{tabular}{|c|c|c|c|c|c|}
\hline Autor/Título & Detalhes do trabalho & $\begin{array}{l}\text { Posição sobre o } \\
\text { RMF }\end{array}$ & $\overline{\text { Método de análise }}$ & $\begin{array}{l}\text { Países } \\
\text { estudados }\end{array}$ & $\overline{\text { Principais Resultados }}$ \\
\hline $\begin{array}{l}\text { Pierre e Anderson }(1984)^{\star} \\
\text { "An Analysis of the Fac- } \\
\text { tors Associated with Law- } \\
\text { suits Against Public Accoun- } \\
\text { tants" }\end{array}$ & $\begin{array}{l}\text { Publicado } \\
\text { The Accounting Review }\end{array}$ & Contra & $\overline{A R C H I V A L}$ & EUA & $\begin{array}{l}\text { O número de processos aumenta com a novos } \\
\text { relacionamentos entre auditor-cliente. }\end{array}$ \\
\hline $\begin{array}{l}\text { SDA Bocconi School of Ma- } \\
\text { nagement }(2002)^{\star} \\
\text { "The impact of mandatory } \\
\text { audit rotation on audit qua- } \\
\text { lity and on audit pricing: the } \\
\text { case of Italy" }\end{array}$ & Não publicado & Contra & $\begin{array}{l}A R C H I V A L \\
\text { (análise quantitativa) } \\
\text { QUESTIONÁRIOS }\end{array}$ & Itália & $\begin{array}{l}\text { Rodízio mandatório produz efeitos positivos } \\
\text { sobre a independência do auditor percebida, } \\
\text { mas gera altos custos sociais. }\end{array}$ \\
\hline $\begin{array}{l}\text { Silva e Bezerra (2010) } \\
\text { "Análise do Gerenciamento } \\
\text { de Resultados e o Rodízio de } \\
\text { Firmas de Auditoria nas Em- } \\
\text { presas de Capital Aberto" }\end{array}$ & $\begin{array}{l}\text { Publicado } \\
\text { Revista Brasileira de Gestão } \\
\text { de Negócios }\end{array}$ & Contra & Archival & Brasil & $\begin{array}{l}\text { Observou-se que a troca de auditor não está } \\
\text { diretamente relacionada à diminuição do ge- } \\
\text { renciamento de resultados }\end{array}$ \\
\hline $\begin{array}{l}\text { Silvestre (2016) } \\
\text { "Rodízio de auditoria e quali- } \\
\text { dade dos lucros: uma análise } \\
\text { a partir dos accruals residu- } \\
\text { ais" }\end{array}$ & $\begin{array}{l}\text { Dissertação (mestrado) } \\
\text { Universidade do Vale do Rio } \\
\text { dos Sinos }\end{array}$ & & Archival & Brasil & $\begin{array}{l}\text { Verificou-se gerenciamento de resultados após } \\
\text { rodízio de auditores através de accruals dis- } \\
\text { cricionários. Resultados dependem do modelo } \\
\text { usado. Para rodízio voluntário verificou-se di- } \\
\text { minuição na qualidade. }\end{array}$ \\
\hline $\begin{array}{l}\text { Vanstraelen }(2000)^{\star} \\
\text { "Impact of renewable long- } \\
\text { term audit mandates on au- } \\
\text { dit quality" }\end{array}$ & $\begin{array}{l}\text { Publicado } \\
\text { The European Accounting } \\
\text { Review }\end{array}$ & A favor & $\begin{array}{l}\text { ARCHIVAL } \\
\text { Análises univariadas }\end{array}$ & Bélgica & $\begin{array}{l}\text { Longo período de relacionamento auditor- } \\
\text { cliente aumenta significativamente a probabi- } \\
\text { lidade de um relatório de auditoria sem res- } \\
\text { salvas. }\end{array}$ \\
\hline $\begin{array}{l}\text { Walker et al. }(2001)^{\star} \\
\text { "Mandatory auditor rota- } \\
\text { tion: Arguments and current } \\
\text { evidence" }\end{array}$ & $\begin{array}{l}\text { Publicado } \\
\text { Accounting Enquiries }\end{array}$ & Contra & $A R C H I V A L$ & EUA & $\begin{array}{l}\text { A taxa de falha é muito menor em relaciona- } \\
\text { mentos de longo prazo. }\end{array}$ \\
\hline $\begin{array}{l}\text { Wu Xi e Zhang (2013) } \\
\text { "Change for Change's Sake } \\
\text { ? Does Mandatory Part- } \\
\text { ner Rotation Improve Audit } \\
\text { Quality?" }\end{array}$ & $\begin{array}{l}\text { Não publicado } \\
\text { (ACCOUNTING, MIT } \\
\text { ASIA CONFERENCE IN } \\
\text { SHANHAI) }\end{array}$ & A favor & $\begin{array}{l}\text { Archival } \\
\text { (regressão de ajustes na } \\
\text { auditoria, contra o sócio } \\
\text { estar no primeiro ou no } \\
\text { último ano de relaciona- } \\
\text { mento com o cliente e con- } \\
\text { tra outras variáveis de con- } \\
\text { trole) }\end{array}$ & China & $\begin{array}{l}\text { O rodízio mandatório de sócios de auditoria } \\
\text { resulta em auditorias de maior qualidade. Es- } \\
\text { pecificamente, há uma freqüência significati- } \\
\text { vamente maior de ajustes de auditoria du- } \\
\text { rante o último ano do sócio de auditoria antes } \\
\text { do rodízio mandatório e durante o primeiro } \\
\text { ano de relacionamento do novo sócio de audi- } \\
\text { toria. }\end{array}$ \\
\hline
\end{tabular}


Tabela 11 - (continuação)

\begin{tabular}{|c|c|c|c|c|c|}
\hline Autor/Título & Detalhes do trabalho & $\begin{array}{c}\text { Posição sobre o } \\
\text { RMF }\end{array}$ & Método de análise & $\begin{array}{c}\text { Países } \\
\text { estudados }\end{array}$ & Principais Resultados \\
\hline $\begin{array}{l}\text { Aninat et al. (2015) } \\
\text { "The effect of rotation } \\
\text { among audit firms: an event } \\
\text { study in Chile" }\end{array}$ & $\begin{array}{l}\text { Não publicado } \\
\text { (relatório técnico) }\end{array}$ & Contra & Modelo analítico & Chile & $\begin{array}{l}\text { O aumento nos custos de auditoria é positiva- } \\
\text { mente correlacionado com a duração do relaci- } \\
\text { onamento auditor-auditado antes da introdu- } \\
\text { ção do rodízio mandatório. No Chile, os cus- } \\
\text { tos da mudança de auditores seriam maiores } \\
\text { que o benefício, visto que os custos de transa- } \\
\text { ção seriam aumentados. }\end{array}$ \\
\hline $\begin{array}{l}\text { Arruñada e Paz-Ares } \\
(1997)^{\star} \\
\text { "Mandatory rotation of com- } \\
\text { pany auditors: A critical } \\
\text { examination" }\end{array}$ & $\begin{array}{l}\text { Publicado } \\
\text { International Review of Law } \\
\text { and Economics }\end{array}$ & Contra & Pesquisa analítica & & $\begin{array}{l}\text { O rodízio mandatório de firmas aumenta os } \\
\text { custos de produção (Auditor). }\end{array}$ \\
\hline $\begin{array}{l}\text { Cameran, Francis, et al. } \\
(2015) \\
\text { "Are There Adverse Conse- } \\
\text { quences of Mandatory Audi- } \\
\text { tor Rotation? Evidence from } \\
\text { the Italian Experience" }\end{array}$ & $\begin{array}{l}\text { Publicado } \\
\text { Auditing: a Journal of Prac- } \\
\text { tice \& Theory }\end{array}$ & Contra & Archival & Itália & $\begin{array}{l}\text { Os custos relacionados ao rodízio mandatório } \\
\text { não são triviais, mas que poderiam ser aceitá- } \\
\text { veis caso a qualidade da auditoria fosse melho- } \\
\text { rada. Porém a qualidade dos lucros auditados } \\
\text { é menor nos primeiros anos após a rotação, } \\
\text { do que nos anos posteriores do mandato do } \\
\text { auditor }\end{array}$ \\
\hline $\begin{array}{l}\text { SDA Bocconi School of Ma- } \\
\text { nagement }(2002){ }^{\star} \\
\text { "The impact of mandatory } \\
\text { audit rotation on audit qua- } \\
\text { lity and on audit pricing: the } \\
\text { case of Italy" }\end{array}$ & Não publicado & Contra & $\begin{array}{l}\text { ARCHIVAL } \\
\text { (análise quantitativa) } \\
\text { QUESTIONÁRIOS }\end{array}$ & Itália & $\begin{array}{l}\text { No primeiro ano de contrato com o auditor, } \\
\text { tanto os custos internos do auditado, quanto } \\
\text { os do auditor, são maiores. }\end{array}$ \\
\hline \multicolumn{6}{|c|}{ (iv) Rodízio mandatório de firmas e a competição no mercado de auditoria } \\
\hline $\begin{array}{l}\text { Arruñada e Paz-Ares } \\
(1997)^{\star} \\
\text { "Mandatory rotation of com- } \\
\text { pany auditors: A critical } \\
\text { examination" }\end{array}$ & $\begin{array}{l}\text { Publicado } \\
\text { International Review of Law } \\
\text { and Economics }\end{array}$ & Contra & Pesquisa analítica & & $\begin{array}{l}\text { Distorção da concorrência através de uma di- } \\
\text { visão artificial do mercado. }\end{array}$ \\
\hline $\begin{array}{l}\text { SDA Bocconi School of Ma- } \\
\text { nagement }(2002)^{\star} \\
\text { "The impact of mandatory } \\
\text { audit rotation on audit qua- } \\
\text { lity and on audit pricing: the } \\
\text { case of Italy" }\end{array}$ & Não publicado & Contra & $\begin{array}{l}\text { Archival } \\
\text { (análise quantitativa) } \\
\text { QUESTIONÁRIOS }\end{array}$ & Itália & $\begin{array}{l}\text { O rodízio mandatório de firmas leva a uma } \\
\text { maior concentração de mercado e a probabili- } \\
\text { dade de conluio entre empresas de auditoria } \\
\text { é aumentada. }\end{array}$ \\
\hline
\end{tabular}

(v) Rodízio mandatório de firmas e a reação do mercado de capitais 
Tabela 11 - (continuação)

\begin{tabular}{|c|c|c|c|c|c|}
\hline "Autor/Título & Detalhes do trabalho & $\begin{array}{c}\text { Posição sobre o } \\
\text { RMF }\end{array}$ & Método de análise & $\begin{array}{c}\text { Países } \\
\text { estudados }\end{array}$ & 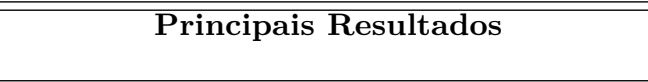 \\
\hline $\begin{array}{l}\text { Davis et al. }(2009) \\
\text { Auditor tenure and the abi- } \\
\text { lity to meet or beat earnings } \\
\text { forecasts }\end{array}$ & $\begin{array}{l}\text { Publicado } \\
\text { Forthcoming in Contempo- } \\
\text { rary Accounting Research }\end{array}$ & Contra & $\begin{array}{l}\text { Archival } \\
\text { (Regressão entre ac- } \\
\text { cruals discricionários, } \\
\text { período de relaciona- } \\
\text { mento auidor-auditado } \\
\text { e outras variáveis de } \\
\text { controle) }\end{array}$ & & $\begin{array}{l}\text { Firmas com um período de relacionamento } \\
\text { auditor-auditado muito curto ou muito longo } \\
\text { têm maior propensão a reportar níveis de ac- } \\
\text { cruals discricionários que façam com que o lu- } \\
\text { cro vá de encontro às previsões dos analistas, } \\
\text { mas esse efeito deixo de existir após a SOX, } \\
\text { evidenciando que os mecanismo implementa- } \\
\text { dos pela referida lei foram eficazes, não ha- } \\
\text { vendo necessidade de rodízio mandatório de } \\
\text { firmas de auditoria. }\end{array}$ \\
\hline $\begin{array}{l}\text { Datar et al. (1991) } \\
\text { "The role of audits and au- } \\
\text { dit quality in valuing new is- } \\
\text { sues" }\end{array}$ & $\begin{array}{l}\text { Publicado } \\
\text { Journal of Accounting and } \\
\text { Economics }\end{array}$ & & $\begin{array}{l}\text { Archival } \\
\text { (Regressão entre o valor } \\
\text { inicial da oferta pública de } \\
\text { ações e a qualidade da au- } \\
\text { ditoria) }\end{array}$ & & $\begin{array}{l}\text { O valor da auditoria é maior, quanto maior } \\
\text { forem a qualidade da auditoria e o risco espe- } \\
\text { cífico da firma com que o investidor se depara. } \\
\text { E o valor da auditoria é uma função crescente } \\
\text { das expectativas dos empresários a respeito } \\
\text { do valor futuro da firma. }\end{array}$ \\
\hline $\begin{array}{l}\text { Francis e Ke }(2006) \\
\text { "Disclosure of fees paid to au- } \\
\text { ditors and the market valua- } \\
\text { tion of earnings surprises" }\end{array}$ & $\begin{array}{l}\text { Publicado } \\
\text { Review of Accounting Stu- } \\
\text { dies }\end{array}$ & A favor & & & \\
\hline $\begin{array}{l}\text { Frankel et al. (2002) } \\
\text { "The relation between audi- } \\
\text { tors' fees for nonaudit ser- } \\
\text { vices and earnings manage- } \\
\text { ment" }\end{array}$ & $\begin{array}{l}\text { Publicado } \\
\text { The Accounting Review }\end{array}$ & A favor & $\begin{array}{l}\text { Archival } \\
\text { (Relação entre os honorá- } \\
\text { rios de serviços de não } \\
\text { auditoria e o preço das } \\
\text { ações) }\end{array}$ & & $\begin{array}{l}\text { A prestação de serviços de não auditoria } \\
\text { fortalece o vínculo econômico entre auditor- } \\
\text { auditado e os investidores precificam esse } \\
\text { efeito. Ou seja, os investidores precificam a } \\
\text { redução percebida na independência do audi- } \\
\text { tor. }\end{array}$ \\
\hline $\begin{array}{l}\text { Hohenfels (2016) } \\
\text { "Auditor Tenure and Percei- } \\
\text { ved Earnings Quality" }\end{array}$ & $\begin{array}{l}\text { Publicado } \\
\text { International Journal of Au- } \\
\text { diting }\end{array}$ & & Archival & Alemanha & $\begin{array}{l}\text { Utilizando a qualidade percebida por inves- } \\
\text { tidores e um modelo quadrático em função } \\
\text { da tenure verificou-se que o prazo que resulta } \\
\text { numa qualidade máxima de auditoria é entre } \\
8 \text { e } 9 \text { anos. }\end{array}$ \\
\hline
\end{tabular}


Tabela 11 - (continuação)

\begin{tabular}{|c|c|c|c|c|c|}
\hline Autor/Título & Detalhes do trabalho & $\begin{array}{c}\text { Posição sobre o } \\
\text { RMF }\end{array}$ & Método de análise & $\begin{array}{c}\text { Países } \\
\text { estudados }\end{array}$ & Principais Resultados \\
\hline $\begin{array}{l}\text { Mansi et al. }(2004)^{\star} \\
\text { "Does auditor quality and } \\
\text { tenure matter to investors? } \\
\text { evidence from the bond mar- } \\
\text { ket" }\end{array}$ & $\begin{array}{l}\text { Publicado } \\
\text { Journal of Accounting Rese- } \\
\text { arch }\end{array}$ & Contra & $\begin{array}{l}\text { Archival } \\
\text { (Análise multivariada) }\end{array}$ & EUA & $\begin{array}{l}\text { Características de auditoria são importantes } \\
\text { para os mercados de capitais: (i) a qualidade } \\
\text { auditor e seu período de relacionamento com } \\
\text { o cliente são negativamente e significativa- } \\
\text { mente relacionados com o custo de financia- } \\
\text { mento de dívida, (ii) a relação entre as ca- } \\
\text { racterísticas do auditor e o custo da dívida } \\
\text { é mais pronunciada nas empresas com dívida } \\
\text { em grau de não investimento e (iii) as audi- } \\
\text { torias, tanto no papel de oferecer segurança, } \\
\text { quanto no de oferecer informações, são econo- } \\
\text { micamente significativas para o custo da dí- } \\
\text { vida. }\end{array}$ \\
\hline $\begin{array}{l}\text { Reid e Carcello (2017) } \\
\text { Investor Reaction to the } \\
\text { Prospect of Mandatory Au- } \\
\text { dit Firm Rotation }\end{array}$ & $\begin{array}{l}\text { Publicado } \\
\text { The Accounting Review }\end{array}$ & Contra & $\begin{array}{l}\text { Archival } \\
\text { (Regressão entre Retor- } \\
\text { nos de Mercado, pe- } \\
\text { ríodo de relacionamento } \\
\text { auditor-auditado e outras } \\
\text { variáveis de controle) }\end{array}$ & EUA & $\begin{array}{l}\text { O mercado americano reage negativamente } \\
\text { (positivamente) à eventos que aumentam (di- } \\
\text { minuem) a probabilidade de rotação, embora } \\
\text { esses resultados sejam sensíveis ao indexado- } \\
\text { res de mercado usados para calcular retornos } \\
\text { anormais, proxy utilizada para medir a quali- } \\
\text { dade de auditoria. }\end{array}$ \\
\hline $\begin{array}{l}\text { SDA Bocconi School of Ma- } \\
\text { nagement }(2002)^{\star} \\
\text { "The impact of mandatory } \\
\text { audit rotation on audit qua- } \\
\text { lity and on audit pricing: the } \\
\text { case of Italy" }\end{array}$ & Não publicado & Contra & $\begin{array}{l}\text { Archival } \\
\text { (análise quantitativa) } \\
\text { QUESTIONÁRIOS }\end{array}$ & Itália & $\begin{array}{l}\text { Os mercados financeiros não gostam do rodí- } \\
\text { zio mandatório porque esta regra não se ofe- } \\
\text { rece ass ferramentas de mercado para punir a } \\
\text { empresa. }\end{array}$ \\
\hline $\begin{array}{l}\text { Titman e Trueman (1986) } \\
\text { "Information quality and the } \\
\text { valuation of new issues" }\end{array}$ & $\begin{array}{l}\text { Publicado } \\
\text { Journal of Accounting and } \\
\text { Economics }\end{array}$ & A favor & Modelo analítico & & $\begin{array}{l}\text { A demanda por auditorias de qualidade está } \\
\text { associada a menores riscos de payoff da firma } \\
\text { (ou projeto), visto que os agentes internos da } \\
\text { empresa terão incentivos para revelar informa- } \\
\text { ção privilegiada e assim, obter uma avaliação } \\
\text { favorável dos investidores (ou credores). }\end{array}$ \\
\hline \multicolumn{6}{|c|}{ (vI) Prazo para o rodízio mandatório de auditoria } \\
\hline $\begin{array}{l}\text { Cheng e Zhang (2015) } \\
\text { "On the Optimal Year of Au- } \\
\text { ditor Rotation" }\end{array}$ & Não publicado & & Modelo analítico & & $\begin{array}{l}\text { São feitas considerações sobre a formulação } \\
\text { matemática da qualidade da auditoria em ter- } \\
\text { mos da competência e da independência. Tam- } \\
\text { bém é apresentada uma forma de se chegar a } \\
\text { um prazo ótimo para o rodízio de firmas de } \\
\text { auditoria. }\end{array}$ \\
\hline
\end{tabular}


Tabela 11 - (continuação)

\begin{tabular}{|c|c|c|c|c|c|}
\hline Autor/Título & Detalhes do trabalho & $\begin{array}{c}\text { Posição sobre o } \\
\text { RMF }\end{array}$ & Método de análise & $\begin{array}{c}\text { Países } \\
\text { estudados }\end{array}$ & $\overline{\text { Principais Resultados }}$ \\
\hline $\begin{array}{l}\text { Brooks et al. (2017) } \\
\text { "Estimates of optimal audit } \\
\text { firm tenure across different } \\
\text { legal regimes" }\end{array}$ & $\begin{array}{l}\text { Publicado } \\
\text { Journal of Accounting, Audi- } \\
\text { ting and Finance }\end{array}$ & & Archival & Vários & $\begin{array}{l}\text { Através da modelagem quadrática da quali- } \\
\text { dade da auditoria em função da tenure são } \\
\text { estimados prazos ótimos para países com } \\
\text { grande e baixo graus de proteção ao investi- } \\
\text { dor, mostrando que o prazo ótimo é significan- } \\
\text { temente maior nos primeiros. }\end{array}$ \\
\hline
\end{tabular}




\section{APÊNDICE B - Questionário}

\section{Percepções sobre a qualidade da auditoria ao longo do tempo}

Esta pesquisa está sendo realizada pela doutoranda Patrícia Romualdo de Almeida, em conjunto com seu orientador Prof. Luiz Nelson Guedes de Carvalho, todos vinculados a FEA/USP. O objetivo da pesquisa é identificar o comportamento da qualidade da auditoria ao longo do tempo, considerando de forma segregada seus componentes competência técnica e independência.

Contatos:

patriciaromualdo@usp.br

patriciaromualdo@hotmail.com

A sua participação será somente para o preenchimento do questionário. Os dados serão analisados por meio de técnicas estatísticas e em nenhum momento você será identificado. Os resultados da pesquisa serão publicados de forma agregada, sendo sua identidade preservada.

Sua participação é de extrema importância! Desde já agradecemos!

*Obrigatório

\section{Área de atuação}

1. Qual a sua ocupação? *

Marque todas que se aplicam.

$\square$ Auditor Sócio
$\square$ Auditor Diretor
$\square$ Auditor Gerente
$\square$ Auditor Senior
$\square$ Acadêmico
$\square$ Diretor de contabilidade
$\square$ Diretor financeiro
$\square$ Analista
$\square$ Outro:

\section{Percepções sobre a competência técnica do auditor}

A competência técnica é aqui entendida como a capacidade de determinado auditor para detectar possíveis falhas no sistema contábil de seu cliente. Isto envolve seus conhecimentos de contabilidade, conhecimento sobre o cliente auditado e seus controles internos, habilidades técnicas do auditor, tecnologia utilizada, procedimentos empregados, extensão dos exames, entre outros.

É consenso na literatura que a competência técnica do auditor em determinado cliente aumenta com o passar do tempo de relacionamento entre auditor-auditado. Nosso objetivo é entender de que forma ocorre este aumento.

2. Na sua percepção, qual das opções abaixo melhor representa o comportamento da competência técnica do auditor em um determinado cliente ao longo do tempo? *

Marcar apenas uma oval. 


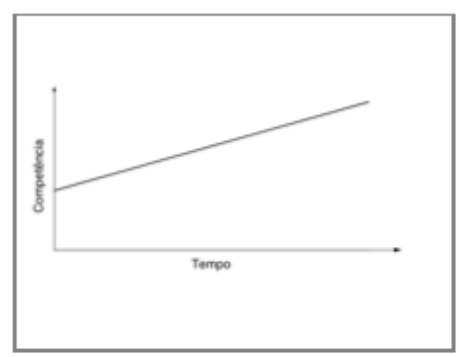

1. Aumenta indefinidamente de forma linear ao longo do tempo

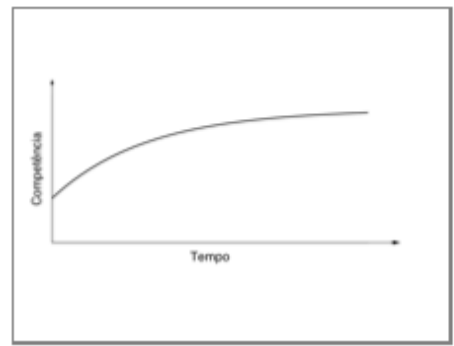

3. Aumenta a uma taxa decrescente até se estabilizar em um patamar superior ao nivel inicial Ir para a pergunta 5 .

\footnotetext{
5. Aumenta de outra forma Ir para a pergunta 4.
}

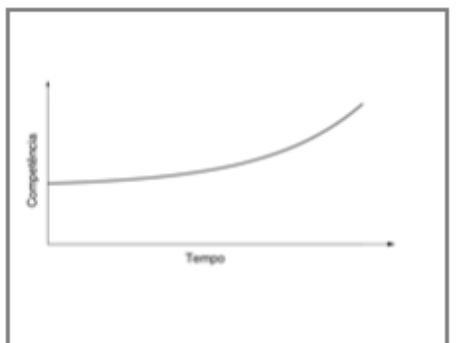

2. Aumenta indefinidamente a uma taxa crescente ao longo do tempo

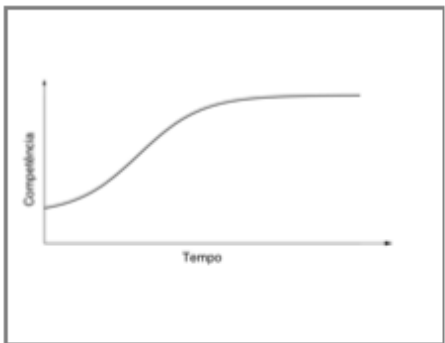

4. Aumenta a diferentes taxas até se estabilizar em um patamar superior ao nivel

6. Ao contrário do mais aceito na literatura, acredito que a competẻncia técnica diminui com o passar do tempo de relacionamento. Ir para a pergunta 3.

3. Explique por que você considera que a competência técnica do auditor diminui ao longo do tempo.

4. Descreva a forma como você considera que a competência técnica aumenta com o passar do tempo.*

\section{Percepções sobre a independência do auditor}

A independẻncia representa a probabilidade de que o auditor informe em seu relatório de auditoria as possiveis falhas identificadas. Devido as diversas facetas do relacionamento auditor-auditado, na literatura acredita-se, em geral, que a independẻncia do auditor em relação a um determinado cliente diminui com o passar do tempo de relacionamento.

5. Na sua percepção, qual das opçöes abaixo melhor representa o comportamento da independência do auditor em relação a determinado cliente ao longo do tempo? *

Marcar apenas uma oval.

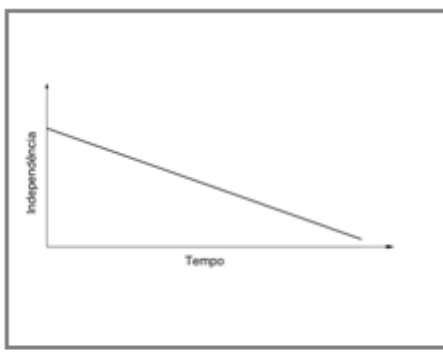

1. Diminui indefinidamente de forma linear ao longo do tempo

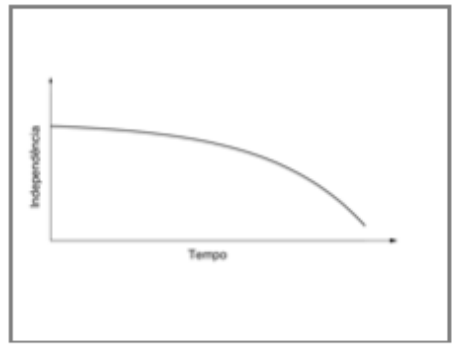

2. Diminui indefinidamente a uma taxa crescente ao longo do tempo 


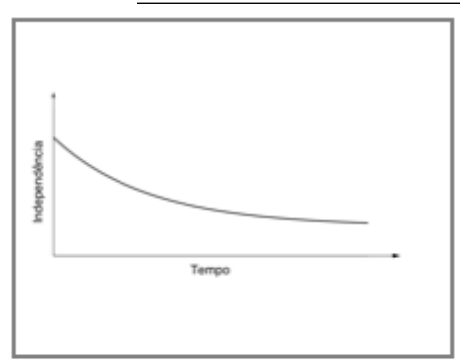

3. Diminui a uma taxa decrescente até se estabilizar em um patamar inferior ao nive

5. Diminui de outra forma Ir para a pergunta 6.

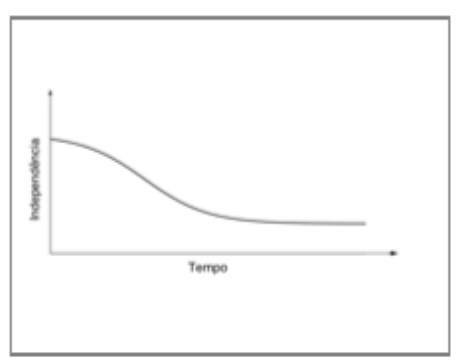

4. Diminui a diferentes taxas até se estabilizar em um patamar inferior ao nivel inicial

6. Ao contrário do mais aceito na literatura, acredito que a independẻncia do auditor aumenta com o passar do tempo de relacionamento. Ir para a pergunta 7.

6. Descreva a forma como vocể considera que a independência diminui com o passar do tempo. *

7. Explique por que você considera que a independência do auditor aumenta com o passar do tempo. *

\section{Percepções sobre a qualidade da auditoria}

8. Na sua percepção, qual das opçöes abaixo melhor representa o comportamento da qualidade de auditoria em um determinado cliente ao longo do tempo? *

Marcar apenas uma oval.

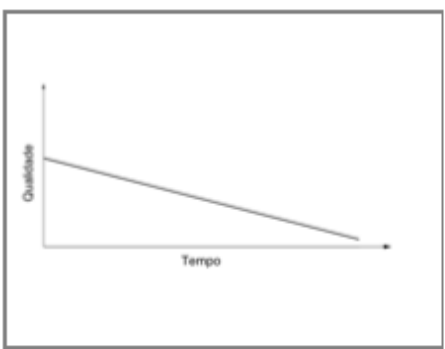

1. Diminui indefinidamente de forma linear ao longo do tempo

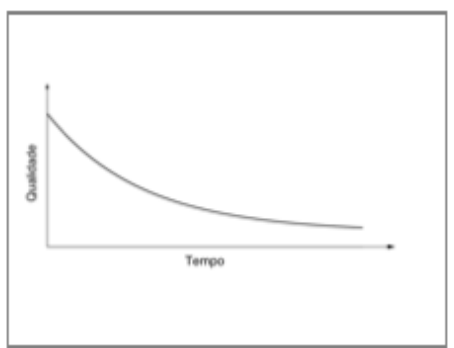

3. Diminui a uma taxa decrescente até se estabilizar em um patamar inferior ao nive inicial

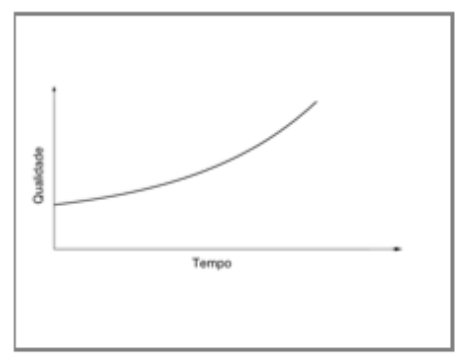

5. Aumenta indefinidamente a uma taxa crescente ao longo do tempo

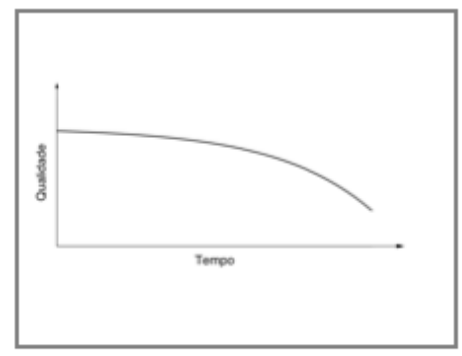

2. Diminui indefinidamente a uma taxa crescente ao longo do tempo

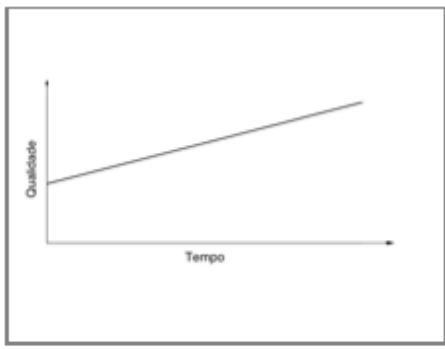

4. Aumenta indefinidamente de forma linear ao longo do tempo

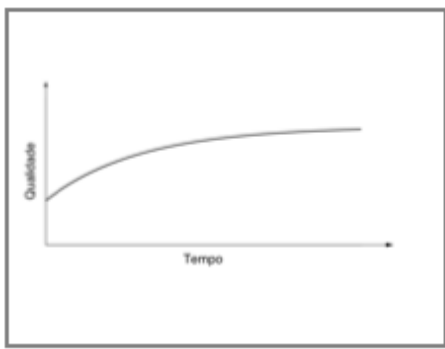

6. Aumenta a uma taxa decrescente até se estabilizar em um patamar superior ao nivel inicial 


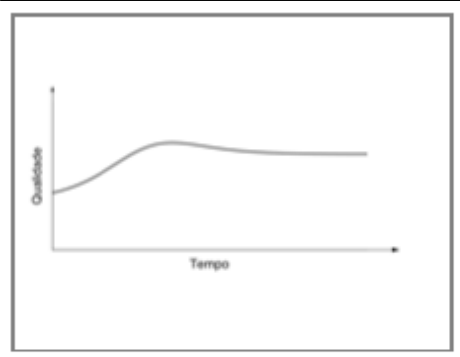

7. Aumenta inicialmente e se estabiliza num patamar superior ao inicial

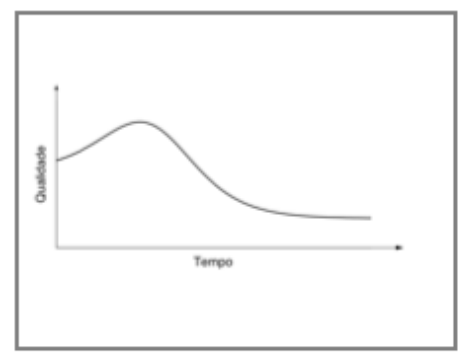

9. Aumenta inicialmente e se estabiliza num patamar abaixo do inicial

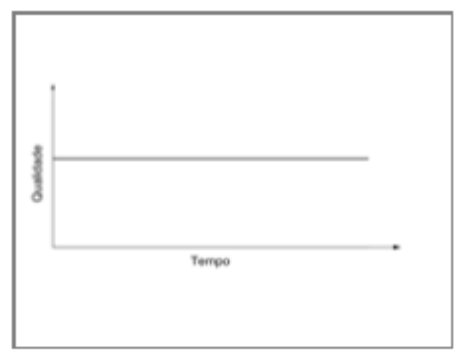

11. Se mantém constante ao lango do tempo

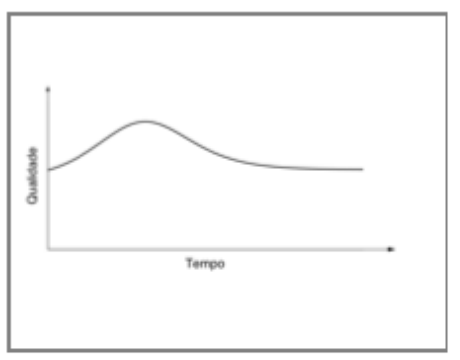

8. Aumenta incialmente e se estabiliza num patamar próximo ao inicial

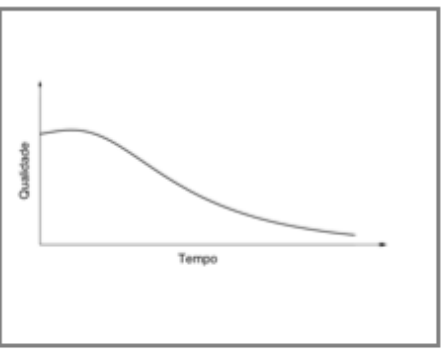

10. Aumenta num primeiro momento e então passa a diminui indefinidamente

Muito obrigado pela sua participação!

Não se esqueça de clicar em enviar, caso contrário não receberemos suas respostas! 


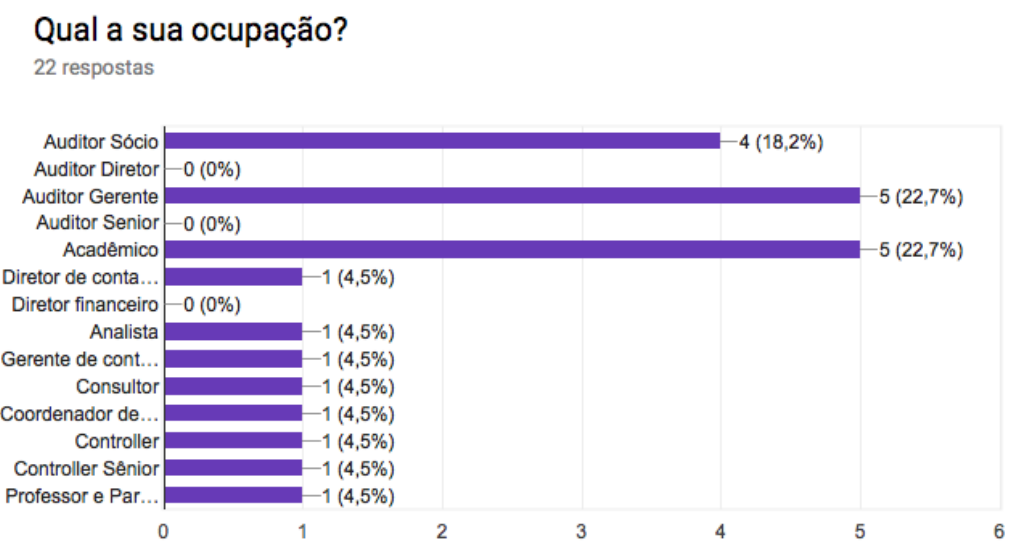

Na sua percepção, qual das opções abaixo melhor representa o comportamento da competência técnic...rminado cliente ao longo do tempo? 22 respostas

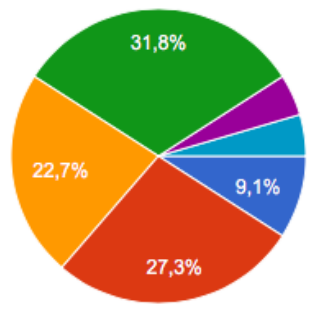

$$
\begin{aligned}
& \text { 1. Aumenta indefinidamente de forma } \\
& \text { linear ao longo do tempo } \\
& \text { 2. Aumenta indefinidamente a uma } \\
& \text { taxa crescente ao longo do tempo } \\
& \text { 3. Aumenta a uma taxa decrescente } \\
& \text { até se estabilizar em um patamar s... } \\
& \text { 4. Aumenta a diferentes taxas até se } \\
& \text { estabilizar em um patamar superior... } \\
& \text { 5. Aumenta de outra forma } \\
& \text { 6. Ao contrário do mais aceito na lit... }
\end{aligned}
$$

Na sua percepção, qual das opções abaixo melhor representa o comportamento da independência do a...erminado cliente ao longo do tempo? 22 respostas

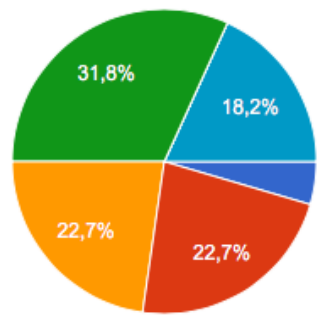

$$
\begin{aligned}
& \text { 1. Diminui indefinidamente de forma } \\
& \text { linear ao longo do tempo } \\
& \text { 2. Diminui indefinidamente a uma } \\
& \text { taxa crescente ao longo do tempo } \\
& \text { 3. Diminui a uma taxa decrescente } \\
& \text { até se estabilizar em um patamar in... } \\
& \text { 4. Diminui a diferentes taxas até se } \\
& \text { estabilizar em um patamar inferior a... } \\
& \text { 5. Diminui de outra forma } \\
& \text { 6. Ao contrário do mais aceito na lit... }
\end{aligned}
$$

Na sua percepção, qual das opções abaixo melhor representa o comportamento da qualidade de audito...erminado cliente ao longo do tempo? 22 respostas

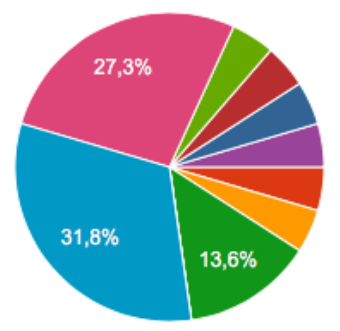

1. Diminui indefinidamente de form...

2. Diminui indefinidamente a uma ta..

3. Diminui a uma taxa decrescente.

4. Aumenta indefinidamente de for..

- 5. Aumenta indefinidamente a uma...

6. Aumenta a uma taxa decrescent...

7. Aumenta inicialmente e se estabi...

8. Aumenta incialmente e se estabil... 



\section{APÊNDICE C - O ponto para rodízio de firma que maximiza a qualidade média de auditoria}

Conforme já discutido, a qualidade da auditoria sofre variações ao longo do tempo de relacionamento de forma que, para se obter um prazo adequado para o rodízio mandatório de firmas de auditoria, há que se maximizar a qualidade média da auditoria para um longo período de tempo como proposto por Cheng e Zhang (2015) e Brooks et al. (2017).

Seguindo esses autores, esse Apêndice apresenta como se pode obter a) o ponto onde a curva da qualidade de auditoria (equação 3.6) atinge seu máximo; b) o ponto onde, após passado o ponto de máximo, a qualidade da auditoria alcança novamente seu valor inicial e; c) o ponto de referência, que é o ponto onde há maior qualidade de auditoria cumulativa (considerando todos os engagements), sendo considerado, portanto, o ponto "ideal" para que ocorra a substituição da firma de auditoria.

Transcrevendo a equação 3.6, que fornece a qualidade da auditoria, temos:

$$
Q A(t)=\alpha_{0}+\alpha_{1} T+\alpha_{2} T^{2}
$$

Considerando $\alpha_{1}>0$ e $\alpha_{2}<0$, de modo que essa equação tenha concavidade virada para baixo, pode-se definir um ponto $\tau$ como ponto máximo da função $Q A(t)$. Para isso, basta se igualar a zero a primeira derivada da função C.1 (que é a transcrição da equação 3.6), conforme mostrado abaixo:

$$
0=\alpha_{1}+2 \alpha_{2} T
$$

de modo a se obter o ponto máximo igual a $\tau=-\alpha_{1} / 2 \alpha_{2}$.

Na equação C.1, a qualidade inicial é igual a $\alpha_{0}$. Então, o ponto em que a função $Q A(t)$ é igual à qualidade inicial, pode ser definido como:

$$
\begin{array}{r}
\alpha_{0}=\alpha_{0}+\alpha_{1} T+\alpha_{2} T^{2}, \\
0=\alpha_{1} T+\alpha_{2} T^{2}, \\
0=\left(\alpha_{1}+\alpha_{2} T\right) T .
\end{array}
$$

A condição apresentada na equação C.2 é satisfeita quando $T=0$ (qualidade de auditoria inicial) ou quando $T=-\alpha_{1} / \alpha_{2}=2 \tau$ (que numa função quadrática, a partir do 
momento em que a qualidade começa a decrescer, representa o ponto em que ela atinge novamente o mesmo nível de qualidade inicial). Isso significa que, após esse ponto, qualquer tenure mais longa significaria qualidade da auditoria inferior à qualidade inicial.

Então, seguindo para a apuração da qualidade média da auditoria durante um longo período de tempo $\left(T_{L}\right)$, em que vários engagements ocorrerão, e considerando que a duração de cada engagement (tenure) será de 0 e $T_{R}$ anos, pode-se definir a qualidade média ao longo do período $T_{L}$ como a área embaixo do gráfico da qualidade da auditoria, ponderada pelo tempo do engagement, vide equação abaixo:

$$
Q A_{\text {med }}=\frac{\frac{T_{L}}{T_{R}} \int_{0}^{T_{R}} Q A(T) d T}{T_{L}},
$$

onde $Q A_{\text {med }}$ é a qualidade média durante um longo período de tempo, $Q A(T)$ é a equação da qualidade de auditoria (C.1) e $T_{L} / T_{R}$ representa o número de engagements existentes nesse longo período que vai de 0 a $T_{L}$.

A partir daí, basta encontrar para qual valor de $T_{R}$ a qualidade média é maximizada. Esta maximização é feita derivando-se a expressão para $Q A_{\text {med }}$ em função de $T_{R}$, igualando esta derivada à zero e isolando o valor de $T_{R}$ como função das demais variáveis. Verifica-se se realmente este seria um período de qualidade média máxima determinando o sinal da derivada segunda de $Q A_{\text {med }}$, que deve ser negativo.

Substituindo a equação inicial da qualidade da auditoria (C.1) na equação C.3 e calculando a integral, dado um ponto $T_{R}$ quando ocorre o rodízio de auditor, é possível se obter a seguinte qualidade média ao longo do período total $T_{L}$ :

$$
\begin{array}{r}
Q A\left(T_{R}\right)_{m e d}=\frac{\frac{T_{L}}{T_{R}}\left(\alpha_{0} T_{R}+\frac{\alpha_{1}}{2} T_{R}^{2}+\frac{\alpha_{2}}{3} T_{R}^{3}\right)}{T_{L}} \\
Q A\left(T_{R}\right)_{m e d}=\alpha_{0}+\frac{\alpha_{1}}{2} T_{R}+\frac{\alpha_{2}}{3} T_{R}^{2}
\end{array}
$$

Derivando a equação acima e igualando a zero, encontra-se então a qualidade média máxima, em que $T_{R}^{*}$ representa o tempo de relacionamento auditor-auditado (a tenure) em que a qualidade média de auditoria assume seu maior valor, vide a seguir:

$$
\begin{array}{r}
0=\frac{\alpha_{1}}{2}+\left(\frac{2 \alpha_{2}}{3} T_{R}^{*}\right), \\
T_{R}^{*}=\frac{-3 \alpha_{1}}{4 \alpha_{2}} .
\end{array}
$$

Como se pode observar,

$$
T_{R}^{*}=\frac{3}{2} \tau
$$


É possível notar também que esse ponto onde se apura a máxima qualidade média de auditoria, naturalmente, devido a qualidade da auditoria se tratar de uma função quadrática, coincide com o valor médio entre os pontos em que a qualidade assume o seu ponto máximo e, novamente, o seu valor inicial, vide demonstração matemática e figura 6 .

$$
\text { PontoMédio }=\frac{2 \tau+\tau}{2}=\frac{3}{2} \tau=T_{R}^{*}
$$

Então, teremos:

Ponto máximo da curva de qualidade da auditoria: $\tau=\frac{-\alpha_{1}}{2 \alpha_{2}}$

Ponto em que a qualidade assume novamente seu valor inicial: $2 \tau$

Ponto em que a qualidade média assume seu maior valor (ponto de referência): $\frac{3}{2} \tau$.

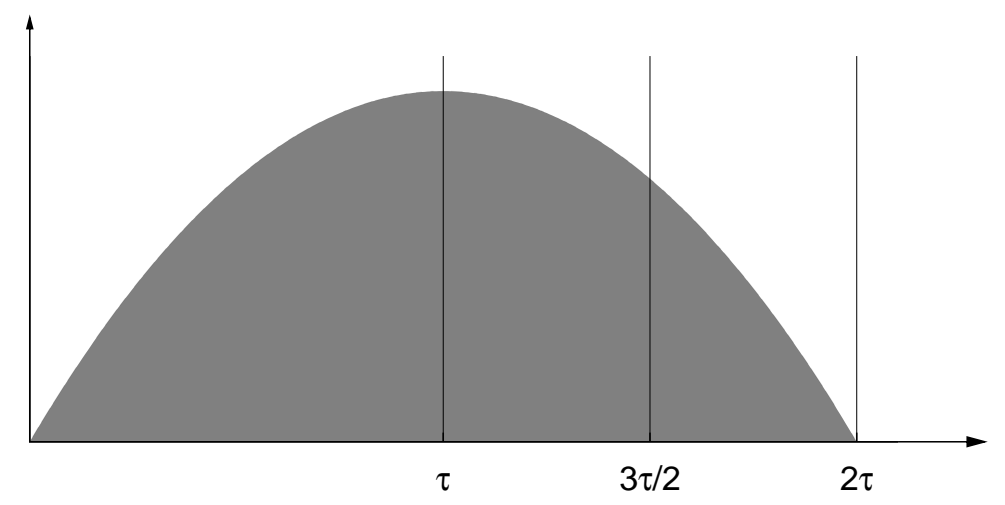

Figura 6 - Esta figura apresenta uma função quadrática, destacando o ponto de máximo $(\tau)$ da curva, o ponto de referência $(3 \tau / 2)$, e o ponto em que a função retorna ao seu valor inicial $(2 \tau)$. 



\section{APÊNDICE D - Resultados das regressões}

\section{D.1 Resultado da regressão do modelo básico sem as variáveis $C O N C$ e $W E D G E$.}

Tabela 12 - Resultado do ajuste por MQO robusto de acordo com a equação 3.7 sem as variáveis $C O N C$ e $W E D G E$.

\begin{tabular}{|c|c|c|c|}
\hline Variáveis & Valor & Erro padrão & $t$ \\
\hline TENURE & 4,239 & 0,039 & $108,42^{* * *}$ \\
\hline$T E N U R E^{2}$ & $-0,573$ & 0,009 & $-65,09 * * *$ \\
\hline$B I G N$ & 1,398 & 0,049 & $28,28 * * *$ \\
\hline ESPEC & 1,260 & 0,233 & $5,42 * * *$ \\
\hline$L E V$ & 0,050 & 0,012 & $4,19^{* *}$ \\
\hline$\tau$ & 3,699 & 0,026 & $143,36^{* * * \dagger}$ \\
\hline $\mathbf{T}_{\mathbf{R}}^{*}$ & 5,548 & 0,039 & $143,36^{* * * \dagger}$ \\
\hline Observações & 6.521 & & \\
\hline R-quadrado & 0,92 & & \\
\hline
\end{tabular}

\section{D.2 Resultados das regressões da variabilidade nos lucros líquidos}

Nesta seção do apêndice são mostrados os resultados das regressões de acordo com a equação 4.1 para cada valor da tenure que forneceu os valores utilizados nas análises apresentadas na seção 4.3 .2

Tabela 13 - Resultado do ajuste por MQO da equação 4.1 para $T E N U R E=1$.

\begin{tabular}{lcccc}
\hline Variáveis & Valor & Erro Padrão & $\mathrm{t}$ & $P>|t|$ \\
\hline SIZE & $0,01^{* *}$ & 0,01 & 2,02 & 0,04 \\
GROWTH & $0,08^{* * *}$ & 0,02 & 3,31 & 0,00 \\
EISSUE & 0,01 & 0,03 & 0,40 & 0,69 \\
LEV_H & 0,00 & 0,00 & 1,15 & 0,25 \\
DISSUE & $-0,08^{* * *}$ & 0,02 & $-3,75$ & 0,00 \\
ATO & $-0,04^{* *}$ & 0,02 & $-2,12$ & 0,03 \\
CFO & $0,23^{* * *}$ & 0,03 & 7,01 & 0,00 \\
BIGN & $-0,04^{*}$ & 0,02 & $-1,77$ & 0,08 \\
Constante & $-0,11^{*}$ & 0,06 & $-1,77$ & 0,08 \\
& & & & \\
Observações & 1.529 & & & \\
R-quadrado & 0,05 & 9,836 & & \\
Valor F & *** $\mathrm{p}<0,01,{ }^{* *} \mathrm{p}<0,05,{ }^{*} \mathrm{p}<0,1$ &
\end{tabular}


Tabela 14 - Resultado do ajuste por MQO da equação 4.1 para $T E N U R E=2$.

\begin{tabular}{|c|c|c|c|c|}
\hline Variáveis & Valor & Erro Padrão & $\mathrm{t}$ & $P>|t|$ \\
\hline$S I Z E$ & $-0,00$ & 0,00 & $-0,24$ & 0,81 \\
\hline GROWTH & $0,04^{* * *}$ & 0,02 & 2,67 & 0,01 \\
\hline EISSUE & 0,04 & 0,03 & 1,50 & 0,13 \\
\hline$L E V \_H$ & 0,00 & 0,00 & 0,51 & 0,61 \\
\hline$D I S S U E$ & $-0,06^{* * *}$ & 0,01 & $-4,23$ & 0,00 \\
\hline$A T O$ & 0,01 & 0,01 & 0,40 & 0,69 \\
\hline $\mathrm{CFO}$ & $0,16^{* * *}$ & 0,04 & 3,61 & 0,00 \\
\hline$B I G N$ & 0,01 & 0,02 & 0,42 & 0,67 \\
\hline Constante & $-0,01$ & 0,05 & $-0,20$ & 0,84 \\
\hline Observações & 1.353 & & & \\
\hline R-quadrado & 0,03 & & & \\
\hline Valor F & 4,522 & & & \\
\hline
\end{tabular}

Tabela 15 - Resultado do ajuste por MQO da equação 4.1 para $T E N U R E=3$.

\begin{tabular}{|c|c|c|c|c|}
\hline Variáveis & Valor & Erro Padrão & $\mathrm{t}$ & $P>|t|$ \\
\hline$S I Z E$ & 0,01 & 0,01 & 1,04 & 0,30 \\
\hline GROWTH & $0,05^{* *}$ & 0,02 & 2,24 & 0,03 \\
\hline EISSUE & $-0,03$ & 0,04 & $-0,88$ & 0,38 \\
\hline$L E V \_H$ & $-0,00$ & 0,00 & $-0,03$ & 0,97 \\
\hline$D I S \overline{S U E}$ & $-0,06^{* *}$ & 0,02 & $-2,58$ & 0,01 \\
\hline$A T O$ & $-0,07 * * *$ & 0,02 & $-3,69$ & 0,00 \\
\hline$C F O$ & $0,40 * * *$ & 0,03 & 11,80 & 0,00 \\
\hline$B I G N$ & 0,01 & 0,03 & 0,24 & 0,81 \\
\hline Constante & $-0,05$ & 0,07 & $-0,74$ & 0,46 \\
\hline Observações & 1.091 & & & \\
\hline R-quadrado & 0,14 & & & \\
\hline Valor F & 21,51 & & & \\
\hline
\end{tabular}

Tabela 16 - Resultado do ajuste por MQO da equação 4.1 para $T E N U R E=4$.

\begin{tabular}{|c|c|c|c|c|}
\hline Variáveis & Valor & Erro Padrão & $\mathrm{t}$ & $P>|t|$ \\
\hline$S I Z E$ & $0,01^{*}$ & 0,01 & 1,93 & 0,05 \\
\hline GROWTH & $0,08^{* *}$ & 0,03 & 2,51 & 0,01 \\
\hline EISSUE & 0,04 & 0,05 & 0,94 & 0,35 \\
\hline$L E V \_H$ & 0,00 & 0,00 & 0,79 & 0,43 \\
\hline$D I S \overline{S U} E$ & $-0,00$ & 0,02 & $-0,12$ & 0,90 \\
\hline$A T O$ & 0,02 & 0,02 & 1,09 & 0,28 \\
\hline$C F O$ & $0,45^{* * *}$ & 0,04 & 11,51 & 0,00 \\
\hline$B I G N$ & $-0,08^{* * *}$ & 0,03 & $-2,60$ & 0,01 \\
\hline Constante & $-0,20^{* *}$ & 0,08 & $-2,49$ & 0,01 \\
\hline Observações & 849 & & & \\
\hline R-quadrado & 0,17 & & & \\
\hline Valor $\mathrm{F}$ & 21,77 & & & \\
\hline
\end{tabular}


Tabela 17 - Resultado do ajuste por MQO da equação 4.1 para TENURE $=5$.

\begin{tabular}{|c|c|c|c|c|}
\hline Variáveis & Valor & Erro Padrão & $\mathrm{t}$ & $P>|t|$ \\
\hline$S I Z E$ & $-0,02^{* *}$ & 0,01 & $-2,40$ & 0,02 \\
\hline GROWTH & 0,05 & 0,04 & 1,23 & 0,22 \\
\hline EISSUE & $0,16^{* * *}$ & 0,05 & 3,11 & 0,00 \\
\hline$L E V \_H$ & 0,00 & 0,00 & 1,33 & 0,18 \\
\hline DISSUE & $-0,07 * *$ & 0,03 & $-2,28$ & 0,02 \\
\hline ATO & $-0,08^{* * *}$ & 0,03 & $-2,82$ & 0,00 \\
\hline$C F O$ & $0,61^{* * *}$ & 0,05 & 12,05 & 0,00 \\
\hline$B I G N$ & 0,04 & 0,04 & 0,91 & 0,36 \\
\hline Constante & $0,25^{* *}$ & 0,10 & 2,49 & 0,01 \\
\hline Observações & 574 & & & \\
\hline R-quadrado & 0,23 & & & \\
\hline Valor F & 21,43 & & & \\
\hline
\end{tabular}

Tabela 18 - Resultado do ajuste por MQO da equação 4.1 para $T E N U R E=6$.

\begin{tabular}{|c|c|c|c|c|}
\hline Variáveis & Valor & Erro Padrão & $\mathrm{t}$ & $P>|t|$ \\
\hline$S I Z E$ & $-0,05^{* * *}$ & 0,01 & $-3,66$ & 0,00 \\
\hline GROWTH & 0,01 & 0,05 & 0,20 & 0,85 \\
\hline EISSUE & $0,16^{*}$ & 0,10 & 1,66 & 0,10 \\
\hline$L E V \_H$ & $-0,00$ & 0,01 & $-0,31$ & 0,76 \\
\hline$D I S S U E$ & $-0,05$ & 0,05 & $-1,04$ & 0,30 \\
\hline$A T O$ & 0,07 & 0,04 & 1,61 & 0,11 \\
\hline$C F O$ & $0,75^{* * *}$ & 0,14 & 5,45 & 0,00 \\
\hline$B I G N$ & $0,11^{*}$ & 0,07 & 1,65 & 0,10 \\
\hline Constante & $0,50 * * *$ & 0,16 & 3,15 & 0,00 \\
\hline Observações & 235 & & & \\
\hline R-quadrado & 0,21 & & & \\
\hline Valor F & 7,417 & & & \\
\hline
\end{tabular}

Tabela 19 - Resultado do ajuste por MQO da equação 4.1 para $T E N U R E=7$.

\begin{tabular}{|c|c|c|c|c|}
\hline Variáveis & Valor & Erro Padrão & $\mathrm{t}$ & $P>|t|$ \\
\hline$\overline{S I Z E}$ & $-0,06$ & 0,04 & $-1,56$ & 0,12 \\
\hline GROWTH & $-0,05$ & 0,12 & $-0,36$ & 0,72 \\
\hline EISSUE & $-0,07$ & 0,21 & $-0,34$ & 0,74 \\
\hline$L E V \_H$ & $-0,01$ & 0,02 & $-0,56$ & 0,58 \\
\hline$D I S \overline{S U} E$ & $-0,02$ & 0,18 & $-0,09$ & 0,93 \\
\hline$A T O$ & $0,25^{*}$ & 0,13 & 1,91 & 0,06 \\
\hline$C F O$ & 0,64 & 0,73 & 0,88 & 0,38 \\
\hline$B I G N$ & $-0,13$ & 0,18 & $-0,73$ & 0,47 \\
\hline Constante & $0,81^{*}$ & 0,45 & 1,81 & 0,08 \\
\hline Observações & 75 & & & \\
\hline R-quadrado & 0,14 & & & \\
\hline Valor F & 1,380 & & & \\
\hline
\end{tabular}





\section{APÊNDICE E - Integração numérica para obtenção da qualidade média}

Neste apêndice detalha-se o procedimento utilizado no cálculo numérico da qualidade média de auditoria empregado na seção 4.3.2. Conforme exposto no apêndice C, a qualidade média para um engagement de $T_{R}$ anos é dada por:

$$
Q A_{\text {med }}=\frac{\frac{T_{L}}{T_{R}} \int_{0}^{T_{R}} Q A(T) d T}{T_{L}}=\frac{\int_{0}^{T_{R}} Q A(T) d T}{T_{R}} .
$$

Assim, como dispõe-se apenas de alguns valores da qualidade da auditoria, $Q A(T)$ para alguns valores da tenure, $T$, recorreu-se a uma integração numérica da expressão acima. A Figura 7 ilustra o procedimento utilizado. Primeiramente, há de se lembrar que a integral de uma função fornece a área abaixo da curva do gráfico desta função. Com isso, o cálculo a ser feito é da área total abaixo da curva dividida pelo intervalo, ou seja,

$$
Q A_{\text {med }}=\frac{\text { Área total }}{T_{R}} .
$$

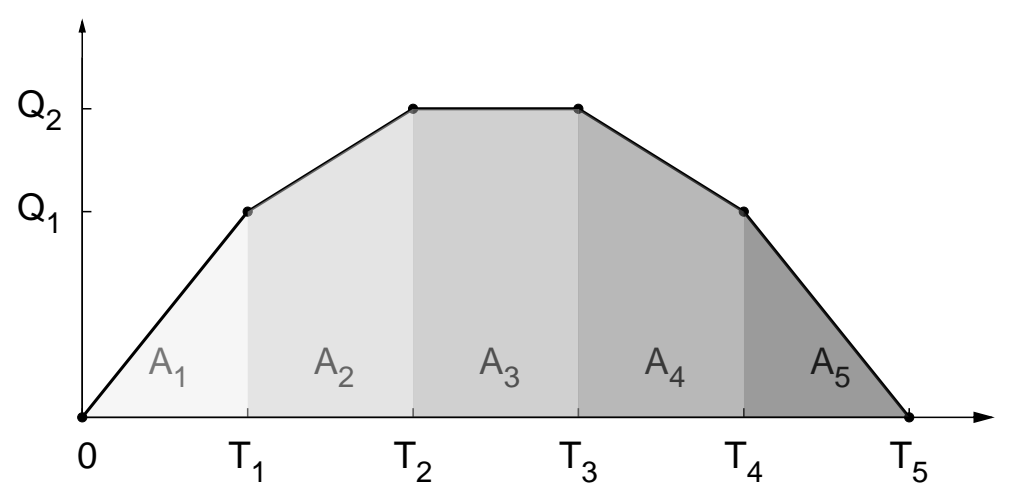

Figura 7 - Ilustração para auxiliar na explicação da integração numérica pela regra do trapézio.

Considerando por um momento, que se deseja estimar a qualidade média para um relacionamento de $T_{3}$ anos, para a situação ilustrada na Figura 7, a área total abaixo da curva é a soma das áreas $A_{1}, A_{2}$ e $A_{3}$, de forma que:

$$
Q A_{\text {med }}=\frac{A_{1}+A_{2}+A_{3}}{T_{3}} .
$$


Perceba que cada uma destas áreas é, de fato, um trapézio ${ }^{1}$. Sabendo que a área de um trapézio é dada por metade da soma da base maior com a base menor multiplicada pela altura, temos:

$$
\begin{aligned}
A_{1} & =\frac{0+Q_{1}}{2\left(T_{1}-0\right)}, \\
A_{2} & =\frac{Q_{2}+Q_{1}}{2\left(T_{2}-T_{1}\right)}, \\
A_{3} & =\frac{Q_{2}+Q_{2}}{2\left(T_{3}-T_{2}\right)} .
\end{aligned}
$$

Assim, para situação ilustrada, a qualidade média num período de $T_{3}$ anos seria dada por:

$$
Q A_{m e d}=\frac{1}{T_{3}}\left(\frac{0+Q_{1}}{2\left(T_{1}-0\right)}+\frac{Q_{2}+Q_{1}}{2\left(T_{2}-T_{1}\right)}+\frac{Q_{2}+Q_{2}}{2\left(T_{3}-T_{2}\right)}\right)
$$

A extensão para o caso geral é imediata. Este método é conhecido como integração pela regra do trapézio e é facilmente encontrada em livros sobre cálculo numérico (e.g. Burden e Faires (2008) e Franco (2007)). 